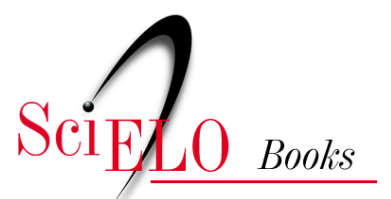

\title{
Vértice do impensável um estudo de narrativas em síndrome de Down
}

\author{
Ana Cristina Bohrer Gilbert
}

\section{SciELO Books / SciELO Livros / SciELO Libros}

GILBERT, A.C.B. Vértice do impensável: um estudo de narrativas em síndrome de Down [online]. Rio de Janeiro: Editora FIOCRUZ, 2012, 174 p. Criança, mulher e saúde collection. ISBN: 978-85-7541572-6. https://doi.org/10.7476/9788575415726.

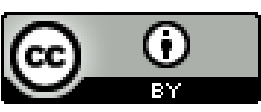

All the contents of this work, except where otherwise noted, is licensed under a Creative Commons Attribution 4.0 International license.

Todo o conteúdo deste trabalho, exceto quando houver ressalva, é publicado sob a licença Creative Commons Atribição 4.0. 
VéRTICE do lMPENSÁVEL UM ESTUDO DE NARRATIVAS EM SÍNDROME DE DOWN 
FUNDAÇÃO OSWALDO CRUZ

Presidente

Paulo Gadelha

Vice-Presidente de Ensino, Informação e Comunicação

Nísia Trindade Lima

EDITORA FIOCRUZ

Diretora

Nísia Trindade Lima

Editor Executivo

João Carlos Canossa Mendes

Editores Científicos

Gilberto Hochman

Ricardo Ventura Santos

Conselho Editorial

Ana Lúcia Teles Rabello

Armando de Oliveira Schubach

Carlos E. A. Coimbra Jr.

Gerson Oliveira Penna

Joseli Lannes Vieira

Ligia Vieira da Silva

Maria Cecília de Souza Minayo

Coleção Criança, Mulher e Saúde

Editoras Responsáveis: Suely Ferreira Deslandes

Maria Elizabeth Lopes Moreira 
Vértice do lMPEnsável UM ESTUDO DE NARRATIVAS EM SÍNDROME DE DOWN

Ana Cristina Bohrer Gilbert 
Copyright (C) 2012 da autora

Todos os direitos desta edição reservados à

Fundação Oswaldo Cruz / EdITORA

Projeto gráfico, capa e editoração eletrônica:

Angélica Mello e Daniel Pose Vazquez

Supervisão editorial:

Janaina S. Silva

Revisão

Jorge Moutinho

Imagens da capa:

A partir de pinturas de Candido Portinari: A Greve (1950, óleo/tela, 55 x 46 cm, coleção particular, São Paulo, SP); Índia e Mulata (1934, óleo/tela, 72 x 50 cm, coleção particular, São Paulo, SP); Meninos com Carneiro (1959, óleo/madeira, 172 x 112 cm, coleção particular, São Paulo, SP); Meninos no Balanço (1960, óleo/tela, 61 x 49 cm, coleção particular, Rio de Janeiro, RJ); Moleques Pulando Cela (1958, óleo/tela, 59,5 x 72,5 cm, coleção particular, São Paulo, SP); Retrato de Maria Grávida (1939, óleo com areia/tela, 45,5 x 33,5 cm, coleção particular, Fortaleza, CE). Nossos agradecimentos a João Candido Portinari pela cessão de direitos de uso das imagens das obras nesta coleção.

Catalogação na fonte

Centro de Informação Científica e Tecnológica

Biblioteca da Escola Nacional de Saúde Pública

G464v Gilbert, Ana Cristina Bohrer

Vértice do impensável: um estudo de narrativas em síndrome de Down.

/ Ana Cristina Bohrer Gilbert. - Rio de Janeiro: Editora Fiocruz, 2012.

175 p.: il (Coleção Criança, Mulher e Saúde)

ISBN: 978-85-7541-299-2

1. Síndrome de Down. 2. Construção Social. 3. Literatura. 4. Arte. I. Título.

CDD - 22.ed. - 616.858842

2012

Editora Fiocruz

Av. Brasil, 4036 - 1 o andar

sala 112 - Manguinhos

21040-361 - Rio de Janeiro - RJ

Tel.: (21) 3882-9039 e 3882-9007

Telefax: (21) 3882-9006

editora@fiocruz.br | www.fiocruz.br/editora 
Ao Peter, sempre 


\section{As CRIATURAS \\ O CORPO \\ O ORGANISMO}

\section{Genética Extraviada}

Os lapsos condenam. A mim, me salvam.

Outro dia olhei um com toda a paciência.

Somos parecidos: a ambos faltam partes $e$, onde a lacuna é norma, em nós pode saltar uma forma esdrúxula, um réquiem ornado de idílios, um troço assim ou, talvez, assado.

De regra, o broto só arrebenta quando está apto a copiar a índole de sua arquidiocese. Para mim e o lapso, não: ambos nascemos de uma abrupta desregulagem. Só ganhamos porque botamos tudo a perder. Miramo-nos como gêmeos sobranceiros: sem herança da paternidade, vértice do impensável, memórias de uma genética extraviada.

João Gilberto Noll

(Mínimos, Múltiplos, Comuns, 2003: 159) 


\section{SUMÁRIO}

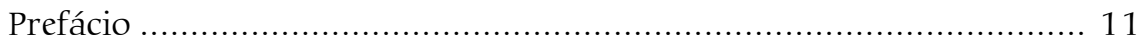

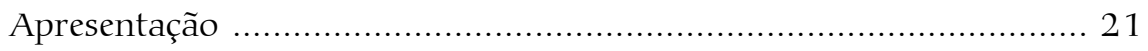

Introdução: a construção de uma composição polifônica sobre um tema principal - categorias sêmicas em síndrome de Down ......... 27

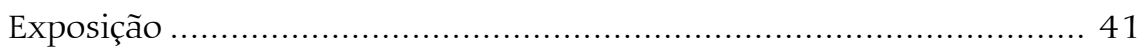

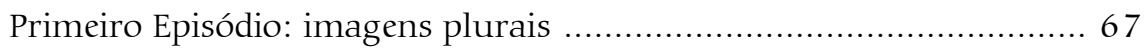

Segundo Episódio: crianças partidas, crianças perfeitas ou as

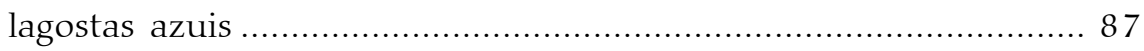

Terceiro Episódio: 'eu sou eu e minha circunstância' ........................ 115

Coda ou um sentido de finalização... ........................................... 151

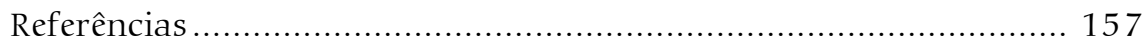




\section{Prefáclo}

De saída, Ana Cristina Bohrer Gilbert avisa de onde veio. Consciente de estar realizando uma pesquisa para uma tese de doutorado, ${ }^{1}$ entretanto não se aferrou às vetustas regras acadêmicas e por isso, neste livro, canta para o leitor que, tal como Fernando Pessoa, numa de suas odes assinadas pelo heterônimo Ricardo Reis, posteriormente ampliada por José Saramago, vai contar um conto do qual faz parte e também contos apreendidos ao ouvir outros contos.

É através de olhos que para lá de ver parecem escutar, passeando por paisagens compostas por escritos de variadas origens e por diversas manifestações iconográficas, que Ana Cristina conduz sua narrativa em cima de outras já construídas, colocando diante de nossos olhos, que até então somente veem, imagens sobre a síndrome de Down. A leitura atenta, continuada, por sua vez, transforma nossos olhos também em olhos que escutam e captam sentidos capazes de produzir novos sentidos que ajudam a compreender como muitos lidam, incluindo nós mesmos, com o vértice do impensável.

E o que é esse vértice? São pessoas ligadas a outras pessoas que fogem, retornam, lutam, desanimam, teimam em esperar na esperança e são obrigadas a pensar naquilo que nunca imaginaram se materializar. $\mathrm{E}$ que também vivem suas diferenças, embora não escapem à ânsia de rotular, massificar, homogeneizar, típica das sociedades ocidentais atuais. É narrar uma história tão antiga quanto o de mais antigo existe, só que 
afastado, tornado invisível por séculos, até aparecer como uma condição que foge à normalidade, cujas marcas estão no interior das células, mas expostas claramente nos corpos. É refletir sobre o imponderável que precisa ser ponderado, mas que para tanto tem que emergir carregado de sentimentos, de emoções e, sobretudo, do que se supõe isento como a ciência, que lhe deu nome e desvendou suas origens.

Sim, é da síndrome de Down que Ana Cristina Bohrer Gilbert fala. Todavia não é dela, exclusivamente dela, mas desse mundo que nos rodeia e das heranças que carregamos sem serem geneticamente transmissíveis. É de novas leituras sobre o velho, porque implica ler a nosso respeito na vida que vivemos. É porque por meio do que nos ameaça, amedronta e assusta erguemos barreiras ou buscamos compensações, nos defendemos, criamos ilusões acerca de nós mesmos e dos outros, fabricamos e divulgamos verdades, cônscios de nossas diferenças, contudo insistindo na tônica de que nascemos e morremos iguais.

No que diz respeito às imagens e à materialidade semiótica da síndrome de Down, houve muitas mudanças. Das primeiras descrições nos tratados médicos, passando pelo afastamento e o silêncio, pelo repúdio eugênico até chegar às publicações vinculadas à genômica e à proteômica, aqui se faz uma narrativa sobre algo que já se apresentava antes, porém não do mesmo jeito de agora, porque investido em momentos diversificados de significados variados. Não se trata de discutir nem os avanços da ciência em si, o que em momento algum é abandonado por Ana Cristina, nem a dicotomia exclusão versus inclusão, característica da contemporaneidade e seu afã pela vendagem mercadológica do politicamente correto. Não é sobre essas dimensões não incorporadas e não corporificadas, de princípios sem gente e pairando acima delas, que se lê. O movimento é bem outro.

Trata-se de realizar etnograficamente o que a antropologia e mesmo a sociologia não veem como tal. É colocar-se diante de um mundo impresso ou virtual e nele ir, atento a si próprio e aos outros, comportando-se respeitosamente com o dito e o não dito; com o sugerido que remete a inúmeras outras palavras, símbolos, enfim, imagens que se encadeiam 
ou não, porém que nunca são essências aprioristicamente dadas. É aplicar conhecimentos localizados, enfoques que só podem humildemente ser parciais (no sentido de não ditatorialmente absolutos em extensão e abrangência), contextualizados e críticos, capazes de perceber uma miríade de conexões e possibilidades, implicando assumir riscos diante dos escritos que se examinam e da iconografia que se analisa. É, acima de tudo, não ser autocentrado, enrijecido em suas convicções, juiz ou júri.

O colocar-se em risco, no processo etnográfico aplicado por Ana Cristina, é seguir, como ela aponta, a diretriz investigativa proposta por Donna Haraway (1997), cuja enunciação pode iludir por sua simplicidade, contudo a instrumentalização demanda faro, golpe de vista e intuição (Ginzburg, 1989), ${ }^{2}$ um acervo de sensibilidade e de cultura. Tudo isso aliado à vigilância constante da autora de se manter aberta a surpresas desestabilizadoras, atenta às teorizações e práticas alheias, posicionandose criticamente, responsável e comprometida com os significados produzidos pelos outros e aqueles engendrados em si própria pela leitura de abundantes e diversificadas fontes.

Foram 164 narrativas em livros assinados por pais, familiares e demais pessoas engajadas em narrar vidas e experiências relacionadas à síndrome de Down. Foram por volta de 350 blogs contendo visões, analogias, metáforas, metonímias, toda uma ampla gama de evocações imagéticas que contavam múltiplas histórias entrelaçadas, compondo, como a própria autora denomina com delicadeza e acuidade interpretativa, 'o desenho do rendilhado'. Foram mais de 150 matérias divulgadas entre 2000 e 2009 no jornal O Globo e na revista Veja, misturando temáticas e abordagens bastante variadas, distribuídas por diversas seções em ambos os meios de comunicação. Filmes enfocando a genética para saudar o espírito humano, como Gattaca; documentários como o brasileiro Do Luto à Luta; episódios de séries feitas pela televisão como um de Lei e Ordem ("Unidade de vítimas especiais"); outras obras cinematográficas ficcionais chegando até a referência de Pedro Almodóvar ao filho rejeitado do teatrólogo americano Arthur Miller, que tinha síndrome de Down, conforme se assiste em Abraços Partidos. 
Mas de onde foi dada a partida para se chegar à escolha desses tipos de fontes? Como estabelecer, dentro das diretrizes etnográficas escolhidas, processos analíticos que dessem conta da micro e da macrossemântica? Como lidar com a diversidade de meios sem levar à dispersão narrativa? Como, ao redor de histórias assinadas por vários autores, produzir sua própria história e nela colocar os significados plurais? Como não ser fragmentária e permanecer imbuída não do senso do todo ou do absoluto, mas da perseverança em contar uma história sobre histórias dando-lhe um ordenamento próprio, sem trair o alheio? Por onde começar a tentar entender para depois construir, pensar criticamente e apresentar de forma inteligível o que os olhos inclinados para cima e para fora, a língua protusa, a microcefalia, enfim, todas as características fenotípicas mais imediatamente perceptíveis, significavam para aqueles que com a síndrome conviviam? Como, no turbilhão das emoções sentidas com o nascimento, e ao longo do decorrer da vida, a questão do retardo mental tornava-se passível de ser pensada, lidada, extravasada e significada?

Psicóloga de formação, leitora apaixonada e sensível, Ana Cristina começou por onde se deve. Em primeiro lugar, por leituras extensas e intensivas sobre a história da síndrome ao longo dos tempos; em segundo, por leituras atentas e apuradas sobre o que o discurso biomédico falou e fala sobre ela; e, por fim, em terceiro, pela análise de materiais produzidos por campanhas visando a incentivar a inclusão e a afastar o estigma social. Uma certa aproximação cuidadosa e comprometida foi se concretizando, porém uma distância teimosa ainda se fazia presente. Tão teimosa que complicava, por tabela, a escolha do material a ser analisado. Saber do retardo mental como ícone da síndrome apontou a flecha para a semiótica e para a assunção da definição e divisão dos signos/sinais de Charles Peirce (1995), enquadrados na moldura do modelo de conhecimento indiciário proposto por Ginzburg (1989). Daí, achar um crivo de análise adequado metodicamente a esses princípios já escolhidos foi um passo rápido na direção que se mostrou eficaz, mas que exigiu todavia muito labor e muitas conversas da autora consigo mesma e com outros para ser executada. 
Foi nesse processo que o slogan da campanha lançada pelo Instituto MetaSocial em 2003, "Ser diferente é normal", soou como alerta. Em torno do sonido, a tônica da normalidade foi se distinguindo como um padrão socialmente disposto. A leitura isotópica, tão bem apresentada por Algirdas Julien Greimas (1987) e minuciosamente agenciada por Ana Cristina, tornou evidente que, consideradas todas as campanhas anteriores e as posteriores a esta, quando o slogan solidificou-se, a categoria do diferente associada a 'condições alteradas', conforme definição do patologista Rudolf Virchow (Entralgo, 1983), estabelece dois semas 'normal/ trissomia 21'. Colocadas no quadrado semiótico, recurso muito pouco adotado nas proposições de análise de narrativas e/ou discursos dentro da academia brasileira, constituindo-se, portanto, em mais uma inovação, ficou claro que o significado implícito ao slogan era 'ser diferente é igual'.

Evidenciava-se desse modo que o reconhecimento da diferença, na verdade, oculta o desejo de ser o 'mesmo'. Mas, na sociedade atual, ainda caminhando pela trilha do iluminismo, com a superioridade humana sendo sinônimo de 'razão', algo que aponta não para a (des)razão da loucura, mas para uma razão partida, leva à necessidade de redenção e reparação pelo lançar mão de outras qualidades que dela se desvinculem. As 'crianças partidas' de Ana Cristina são o protótipo de um anseio de igualdade como análoga à normalidade, em razão do que é percebido como quebra indelével e perene. E assim sendo cabe homogeneizá-las por meio de estratégias de edificação e modulação pública do self, conforme ela aponta, trazendo à tona figuras oníricas como a do 'anjo', imagem já comprovadamente associada às crianças com síndrome de Down (Rogers, 1981; Klein \& Mauseth, 1994; Chang, 1999; Vredevelt, 2000).

Mas esses anjos estão entre nós e eles falam também de nós. Por isso, incontáveis associações com o mundo real e material da natureza se concretizam, metaforizando o cromossomo a mais no par 21, causa da condição, em países com características supostamente intrínsecas, como o calor da Itália em oposição ao frio da Holanda. Se o sonho dos pais era ir ao primeiro, a existência da carga gênica extra no filho os leva ao outro, que, contudo, aprendem a amar até em razão de belezas manifestas como 
as tulipas azuis. A cor violácea de tais tulipas espelha a placidez, a amenidade, a ingenuidade calma, características apontadas como comuns, inerentes e atávicas, até pelo discurso científico de autores como Cliff Cunningham (1996) dirigido aos pais de crianças com a condição. Novamente, segundo a diferença patente, há que se produzir a norma, modulando o 'um' único ser, desconsiderando as circunstâncias do existir de cada um, independentemente do selo gênico.

'Narrativas de fé', consubstanciando enredos de triunfo sobre a tragédia; 'narrativas de presente', asseverando que o viver com uma criança com síndrome de Down é uma dádiva; 'narrativas de perda', enfocando a morte do ideal de filho pelo nascimento da criança marcada pela trissomia do cromossomo 21; 'narrativas de jornada', focalizando os momentos de angústia, melancolia, resolução e alívio, exemplificadas pelo livro O Filho Eterno, do escritor brasileiro Cristovão Tezza (2007); e 'narrativas de capacidades', abrangendo histórias variadas, destinadas a chamar a atenção do público em geral, sobretudo crianças, para como deve ser a convivência com pessoas que têm a síndrome... Todo esse conjunto, cuidadosamente categorizado por Ana Cristina, nos leva para dentro de um mundo que também é nosso, fazendo-nos refletir sobre nossas próprias emoções sentidas e nossas maneiras de lidar com elas.

Do texto publicado ao hipertexto da Internet, nos é mostrado que nossa jornada em busca de transformação do 'outro' no 'mesmo' continua, por meio de estratégias discursivas que acentuam a carga gênica, porém conferem a ela atributo de tesouro a ser zelado, uma lição de amor angelical a ser usufruída, enfim, uma 'mutação' que embaralha 'crianças partidas' e 'lagostas azuis'. A 'imperfeição' genética, como analisa Ana Cristina, é algo a ser prezado tal como as 'lagostas azuis', cuja ocorrência é de uma em dois milhões, sendo motivo de celebração para os pescadores. Afinal, é a anomalia gênica ao provocar uma fuga da norma que as faz raras e preciosas. 'Tulipas azuis e lagostas azuis': será esta escolha da cor fortuita e uma coincidência? O primor, a delicadeza, o cuidado e o compromisso do trabalho de Ana Cristina podem até ser avaliados por uma pequena nota de rodapé em que ela nos relembra que, na língua inglesa, a 
cor azul está associada ao sentimento de tristeza tão presente nas narrativas analisadas.

Foi de inteligência teórica, de seriedade metodológica, de entendimento sem julgamento, de abertura ao inesperado, de respeito aos sentidos produzidos no mundo dos que convivem com a síndrome de Down, que este livro nasceu. Só que não é do 'mesmo' que ele fala, mas do 'outro', daquele 'outro' que todos somos por nunca termos, ao contrário da utopia que insistimos em viver, nascidos iguais. Não é a norma que nos define, porém ser o que cada um é.

Há uma canção famosa, recorrente, mistura de fé e experiência de verdade, com letra e música do canadense Leonard Cohen, que no decorrer da leitura do trabalho de Ana Cristina Bohrer Gilbert retorna à memória em razão de suas nuances e mistura de celebração e dor. É com estes versos que este prefácio termina, para anunciar o que espera o leitor ao longo do texto que se segue:

Baby, I have been here before I know this room, I've walked this floor I used to live alone before I knew you.

I've seen your flag on the marble arch Love is not a victory march It's a cold and it's a broken Hallelujah,

\author{
Hallelujah \\ Hallelujah \\ Hallelujah \\ Hallelujah! ${ }^{3}$
}

Maria Helena Cabral de Almeida Cardoso Historiadora, doutora em Ciências pela Pós-Graduação em Saúde da Criança e da Mulher do Instituto Nacional de Saúde da Mulher, da Criança e do Adolescente Fernandes Figueira da Fundação Oswaldo Cruz (PGSCM/IFF/Fiocruz), pesquisadora do Departamento de Genética do IFF/Fiocruz e docente da PGSCM/IFF/Fiocruz 
1 A tese foi defendida no Programa de Pós-Graduação em Saúde da Criança e da Mulher do Instituto Nacional de Saúde da Mulher, da Criança e do Adolescente Fernandes Figueira, da Fundação Oswaldo Cruz (PGSM/IFF/Fiocruz). Este livro, na realidade, foi resultado do entusiasmo da banca que enfaticamente recomendou que o estudo fosse publicado imediatamente na forma de livro, com as devidas adaptações para tal. Eu tive a honra, na condição de orientadora, de ter participado do caminho de chegada até aqui, contando também com a leitura cuidadosa da dra. Maria Auxiliadora Monteiro Villar como coorientadora.

2 'Intuição', no sentido auferido por Ginzburg, relaciona-se à firasa, fundamento da antiga fisiognomia árabe que se associava com a capacidade dos homens de passar do conhecido para o desconhecido, na base de indícios.

3 Pedindo desculpas ao autor e ao leitor, os versos poderiam, mais ou menos, ser assim traduzidos livremente: "Querida, eu estive aqui antes / eu conheço este quarto, eu caminhei por esse chão / eu costumava morar sozinho antes de te conhecer. / Eu vi sua bandeira no arco de mármore / o amor não é uma marcha de vitória / é uma fria, é uma partida aleluia. / Aleluia, Aleluia, Aleluia, Aleluia". Sugere-se ao leitor procurar ouvir a música na versão gravada por Jeff Buckley, para entender melhor ainda e sentir o porquê da escolha desses versos. Quem o desejar pode acessar o vídeo. Disponível em: <http://www.lastfm.com.br/music/Jeff+Buckley/+videos > . Acesso em: 5 ago. 2010 .

REFERÊNCIAS

CHANG, B. Light into Dawn-Randy's Miracle. City, ST: Mimosa, 1999.

CUNNINGHAM, C. Understanding Down Syndrome: an introduction for parents. Cambridge: Brookline Books, 1996.

ENTRAlGO, L. P. Historia de la Medicina. Barcelona: Salvat, 1983.

GINZBURG, C. Mitos, Emblemas e Sinais: morfologia e história. São Paulo: Companhia das Letras, 1989.

GREIMAS, A. J. On Meaning: selected writings in semiotic theory. Minneapolis: University of Minnesota Press, 1987.

HARAWAY, D. J. Modest_Witness@Second_Millenium.FemaleMan ${ }^{\odot}$ Meets_ OncoMouse $^{\mathrm{TM}}$. Feminism and Technoscience. New York, London: Routledge, 1997. 
KLEIN, L. \& MAUSETH, P. Are There Stripes in Heaven? Mahwah: Paulist Press, 1994.

PEIRCE, C. S. Semiótica. São Paulo: Perspectiva, 1995.

ROGERS, D. E. Angel Unaware: a touching story of love and loss. Grand Rapids, MI: Fleming H. Revell, 1981.

TEZZA, C. O Filho Eterno. Rio de Janeiro: Record, 2007.

VREDEVELT, P. Angel Behind the Rocking Chair: glimpses of glory in unexpected places. Boston: G. K. Hall \& Co., 2000. 


\section{Apresentaçẽo}

"Somos contos contando contos, nada", disse-o Ricardo Reis, heterônimo de Fernando Pessoa (1994: 147), numa de suas odes. "Somos contos de contos contando contos, nada", acrescentou-lhe José Saramago (1998: 235). Como seres de palavras, continua Saramago (1998: 235), "vamos pelo mundo contando o conto que somos e os contos que aprendemos", num infinito legado de palavras.

Neste livro, que teve origem em minha tese de doutorado apresentada ao Programa de Pós-Graduação em Saúde da Criança e da Mulher do Instituto Nacional de Saúde da Mulher, da Criança e do Adolescente Fernandes Figueira, da Fundação Oswaldo Cruz (PSGM/IFF/Fiocruz), conto histórias das histórias que são contadas sobre pessoas com síndrome de Down (SD) e, de certa forma, dou continuidade a uma história que foi contada alhures, em outra tese. ${ }^{1}$

Para se contar histórias é importante atentar para a exatidão das palavras, que devem ser escolhidas minuciosamente a fim de transmitirem o que se propõem com clareza, exatidão e ritmo certo, sem cristalizarse numa única perspectiva e permitindo o despertar de múltiplas imagens no leitor, como bem o descreveu Italo Calvino (1990).

Imbuída dessa tarefa narrativa, sendo eu também uma narrativa construída dia a dia pelo viver, busco refletir sobre as histórias que me foram indiretamente contadas, apreendidas no ar, no comportamento das pessoas, nas imagens, nas palavras não ditas, mas apenas sugeridas, elas mesmas imagens que comportam inúmeras outras. 
Apesar das várias referências e metáforas literárias aqui presentes, recuperei na memória do afeto um elemento que me foi muito caro como aluna de piano e ainda hoje o é como apreciadora de Johann Sebastian Bach: a fuga, e a escolhi como metáfora musical para melhor expressar a organização do livro.

Segundo The Concise Oxford Dictionary of Music (Kennedy \& Kennedy, 2007), a fuga é um tipo de composição de origem barroca que desenvolve um tema principal por meio do contraponto, ${ }^{2}$ da polifonia e da imitação. Esse tema principal é repetido por diversas vozes que se sucedem e perduram de forma entrelaçada. Após a exposição do tema ou sujeito, cada entrada de voz corresponde a um episódio, e a seção final se desenvolve como uma recapitulação das ideias musicais já apresentadas ou uma coda, que pode ou não conter a repetição de tais ideias.

Nessa 'fuga literária', a SD apresenta-se como o sujeito, o tema principal, ao qual se voltará inúmeras vezes, repetido por diferentes vozes - as diversas fontes analisadas, resultando numa composição complexa de imagens cuidadosamente entrelaçadas.

Porém, antes da 'execução' propriamente dita da fuga, é necessário narrar o processo de sua construção, isto é, o processo de construção da pesquisa que serviu de base para esta obra. Assim, na Introdução, apresentam-se ao leitor os procedimentos metodológicos utilizados, no sentido de documentar como a investigação foi conduzida. Explicita-se a noção de etnografia que orientou o estudo e situa-se a análise das fontes no campo da semiótica, dado o interesse em acessar e compreender a realidade apresentada nas narrativas sobre SD. Ao se trabalhar com fontes tão diversas, como fotografias, filmes, livros, blogs e reportagens, é fundamental se levar em consideração mais do que o material óbvio, aparente; aquilo que se oferece de forma sutil, tênue, às vezes quase imperceptível, e que somente olhos e ouvidos voltados para os indícios podem apreender é decisivo para se perceber o universo de análise. Igualmente importante é a escolha das ferramentas para se ordenar o material coletado e sistematizar a sua leitura - no caso, o método de leitura isotópica e sua representação gráfica, o quadrado semiótico, que, ao contrário de restringir interpretações 
pelo estabelecimento de uma única perspectiva, permite múltiplos desdobramentos e possibilidades.

A 'Exposição' marca o início da fuga: descortina o tema principal, a $\mathrm{SD}$, como uma das paisagens biológicas inseridas na política vital contemporânea, delineada pelo agrupamento de pessoas em torno de uma condição biológica específica, que cada vez mais se compreendem e se definem como indivíduos somáticos. Expõem-se as características peculiares que compõem o panorama da biopolítica molecular e a maneira como estas influenciam o processo de produção de verdades sobre os indivíduos. Empreende-se um breve percurso ao longo do processo de definição da etiologia e do diagnóstico da SD desde o século XIX, as diversas nomenclaturas, até se chegar às pesquisas feitas hoje, no nível molecular, com utilização de modelos animais, na tentativa de compreensão dos efeitos resultantes da carga gênica extra e dos seus produtos proteicos. Termina-se com a noção de construção social da ideia da pessoa com SD, com base na proposição feita por Ian Hacking (2000), no sentido de situar o interesse deste livro na análise das imagens presentes nas narrativas que expressem essa ideia.

Imagens plurais compõem o primeiro episódio ou a primeira entrada de voz, de acordo com a metáfora polifônica. Discute-se um grupo de narrativas que se destacaram durante o curso da pesquisa, seja pela sua presença na mídia impressa e televisiva, como no caso do slogan "Ser diferente é normal" e a fotografia a ele associada em 2003-2004; seja no cinema, como o documentário brasileiro de 2004 Do Luto à Luta, com roteiro e direção de Evaldo Mocarzel, do qual se destaca a imagem utilizada na capa do vídeo e na sua divulgação, representando um casal com SD; ou em publicações tanto no círculo biomédico quanto no não especializado, como a pintura renascentista de Andrea Mantegna representando a Virgem com o Menino Jesus, Madonna col Bambino, conhecida e assumida como representando uma criança com SD, e que é divulgada em livros, sites e blogs em diversos idiomas. Evidencia-se o padrão que serve como referência de comparação para as pessoas com SD e que é veiculado de forma subjacente ao movimento de valorização da diferença e da multiplicidade. 
O segundo episódio, ou a segunda entrada de voz, analisa as narrativas na forma de relatos em livros (coletivos e individuais) e blogs de acesso livre, escritos e produzidos em diversos idiomas por pais de pessoas com SD. Assinala-se como o processo de transmissão de experiências, ao mesmo tempo que se revela particular e vivencial, contribui para a construção e a exposição de uma identidade assentada em aspectos somáticos e compartilhada por um grupo ou comunidade, e dissemina múltiplas verdades que desafiam as estabelecidas. Por meio de exemplos capturados em frases e elementos imagéticos, explicita-se o sistema mitológico, com suas imagens e significados próprios, usado como recurso pelos pais para a compreensão da presença da SD em seus filhos, bem como o emprego de um discurso ambivalente que tenta acomodar o que é percebido como inesperado e diferente com a sua normalização. Observa-se que aquilo que é considerado imperfeição é paulatinamente transmutado em aprimoramento.

O terceiro episódio, ou a terceira entrada de voz, abarca as narrativas veiculadas nas reportagens sobre SD publicadas entre janeiro de 2000 e março de 2009 na revista semanal Veja e no jornal O Globo, as quais se situam num cenário mais amplo em que temas ligados à genética e à plasticidade dos corpos são presenças marcantes no cotidiano das pessoas. As narrativas são distribuídas em três grupos que tratam dos seguintes temas: a inclusão de pessoas com SD na sociedade; a atualização do conhecimento na área da genômica; e o uso de (novas) tecnologias reprodutivas. Enquanto o primeiro grupo apresenta pontos em comum com o episódio anterior, como o mesmo discurso ambivalente, por exemplo, apesar da tentativa de romper com o padrão de normalidade vigente, os outros dois grupos de reportagens seguem um caminho um pouco diferente. A necessidade de escolhas circunstanciais em relação às suas vidas, demandada pela biopolítica molecular aos indivíduos, assume diferentes facetas nesses dois grupos, uma atingindo o leitor mais diretamente do que outra, suscitando questionamentos sobre quais ações levar a cabo diante da informação fornecida por técnicas cada vez mais precisas sobre risco ou sobre a presença da SD num feto ou num embrião, e sobre a possibilidade de intervenção na vitalidade humana em geral e no processo 
reprodutivo, em particular. Por fim, a alusão do título do episódio à frase do filósofo José Ortega y Gasset (2007) sugere uma forma de entendimento do ser humano que inclui a sua dimensão genômica sem, entretanto, a ela reduzi-lo.

Na coda, última parte da fuga, busca-se dar um sentido de finalização a tudo o que foi discutido ao longo do trabalho, apesar da certeza de que é um fim provisório. Nesse momento, todas as vozes se juntam para cantar o tema principal, salientando certas notas, confluindo interpretações até, por fim, silenciarem, deixando o ar impregnado da melodia.

O título deste livro foi retirado de um 'instante ficcional' de João Gilberto Noll (2003), "Genética extraviada", e que serve de epígrafe ao trabalho. 'Instante ficcional' foi o nome dado pelo próprio Noll a esses relatos de no máximo 130 palavras, narrativas mínimas concentradas, que exigem igual atenção na sua leitura.

De maneira semelhante, a expressão 'vértice do impensável' pulsa em poesia e lirismo, sintetizando algo que está presente nas narrativas em SD: o espanto diante daquilo que é vivido como inesperado e inimaginável. Entre tantas leituras possíveis, o instante ficcional de Noll serve como uma metáfora para se falar de alguém com SD. Esta pode ser entendida como uma espécie de 'lapso', uma "interrupção do funcionamento normal" na definição do Dicionário Houaiss (Houaiss, Villar \& Mello Franco, 2004: 1.723), mas que segue uma outra norma, como diz o relato mínimo e como se pode ler em Canguilhem (2002). A 'abrupta desregulagem' nele presente o é também na $\mathrm{SD}$, uma desregulagem que leva células a se dividirem de forma diferente da normal, produzindo gametas com material genético excedente. Rompe-se, assim, a regra de que "o broto só arrebenta quando está apto a copiar a índole de sua arquidiocese" (Noll, 2003: 159), e, por conseguinte, a 'herança da paternidade' sofre uma quebra, um estranhamento, posto que esse broto manifesta algo que não estava presente antes. Torna-se inesperado, memória extraviada, 'vértice do impensável', e por colocar 'tudo a perder' pode abandonar uma identidade idealizada e (re)construí-la em outros termos. 
Gostaria de mencionar a minha gratidão a todos que de algum modo contribuíram para a realização deste livro. Em especial, à Maria Helena Cabral de Almeida Cardoso, orientadora no mestrado e no doutorado, por me trazer para a genética, pela inspiração, estímulo, respeito e amizade a cada volta do caminho; e ainda pela permanente disponibilidade para entusiasmadas discussões teóricas que muito contribuíram para o desenvolvimento das ideias aqui apresentadas. À Maria Cecília de Souza Minayo, a Luis David Castiel, Eloisa Grossman e Maria Auxiliadora Monteiro Villar, pelo incentivo, sensibilidade na leitura e pelas críticas e sugestões, valiosos acréscimos a esta versão. À Neide Rodrigues, por seu olhar acurado e sensível. À Suely Ferreira Deslandes e a todos os envolvidos no processo de editoração do livro, pelo apoio fundamental. Aos colegas do Centro de Genética Médica José Carlos Cabral de Almeida do IFF/Fiocruz, pela acolhida durante a pesquisa. Ao Peter Alentejano Gilbert, pelas numerosas revisões feitas com olhos ao mesmo tempo críticos e ternos e, principalmente, por compartilhar a vida.

NOTAS

1 A tese em questão é de autoria de Maria Helena Cabral de Almeida Cardoso (2000).

2 Contraponto refere-se a linhas musicais diferentes e independentes, mas que formam uma textura coerente, soando harmônicas ao serem tocadas juntas (Kennedy \& Kennedy, 2007). 


\section{INTRODUCÃO \\ A CONSTRUÇ̃̃O DE UMA COMPOSIÇÃO POLIFÔNICA SOBRE UM TEMA PRINCIPAL - CATEGORIAS SÊMICAS EM SÍNDROME DE DOWN}

A construção de uma fuga requer determinadas regras, visando a alcançar o resultado desejado, isto é, uma composição rica em variações, agradável não apenas aos sentidos, mas também à imaginação. Da mesma forma, uma pesquisa resulta de um estudo organizado segundo critérios ou regras, empreendido durante alguns - às vezes muitos - anos. $\mathrm{E}$ para contá-la é preciso dar a conhecer ao leitor o caminho trilhado e os alicerces sobre os quais ela foi construída.

Quando se decide contar uma história, a primeira questão que surge é sobre o ponto de partida. Por onde começar? Onde essa história começa?

Pode-se dizer que começa com o interesse da autora, psicóloga de formação, pelas palavras e pelas imagens e a forma como elas se entrelaçam e se definem umas às outras. Começa também na perspectiva clínica do lidar com o humano, que sempre pautou a sua prática profissional. E atrelado ao interesse e à perspectiva clínica, com a curiosidade sobre a permeabilidade das fronteiras entre os círculos biomédico/científico e o considerado como leigo, e a maneira como as informações produzidas no primeiro são divulgadas e transformadas por meio de códigos culturais compartilhados que servem como mediadores entre a produção e a recepção de mensagens.

Mas, em outra perspectiva, o início dessa história deixa de ser início porque retoma um fio deixado por uma outra história, conforme já dito, que faz vibrar profundamente inquietações quanto aos rumos de um movimento que envolve, mas também aprisiona pessoas com síndrome de Down (SD). 
Este livro analisa as imagens culturalmente produzidas que são veiculadas nas narrativas escritas e iconográficas sobre SD e discute como a presença de uma condição geneticamente determinada torna-se fator estruturante de identidade. Usa-se o termo imagem num sentido bastante amplo, referindo-se não apenas às representações figuradas em si, mas a tudo o que é transmitido por estas e por palavras, compondo significados. Considera-se que a produção cultural sobre SD revela imagens e significados que refletem a maneira como a sociedade se relaciona com pessoas que trazem a marca dessa condição genética particular, articulada àquilo que é convencionado como padrão de normal e patológico, de 'mesmo' e de 'outro', com base no discurso biomédico. $\mathrm{O}$ interesse, pois, em pesquisar as narrativas sobre SD refere-se não à identificação de entendimentos errôneos sobre o assunto com a intenção de corrigi-los, mas à interseção entre os conhecimentos biomédico e leigo para moldar significados sobre a SD.

Para tanto, trabalhou-se com o conceito expandido de etnografia proposto por Donna Haraway (1997), o qual extrapola aquele referente a um tipo de procedimento usado em antropologia, que a define como um método assentado na perspectiva de conhecimentos localizados, enfoques parciais, contextualizados e críticos, com múltiplas possibilidades de conexões, e que implica se colocar em risco em face das práticas e dos discursos sobre os quais se questiona. Estar em risco não significa se identificar com os sujeitos de estudo, tampouco autoidentificar-se, quer dizer, centrarse em suas próprias convicções e fazer julgamentos. É estar diante daquilo que não é identificável e que desafia estabilidades, certezas e maneiras de ser, com um modo de atenção ao mesmo tempo prático e teórico, consciente e responsável, tendo-se claro que se está lidando com propósitos e expectativas próprios e dos outros.

Assim, apesar de este livro não consistir num trabalho etnográfico tradicional, uma vez que a análise centra-se na produção cultural difundida por diferentes meios de comunicação e não no contato direto com pessoas com SD e seus familiares, ocorreu uma imersão na realidade apresentada nas narrativas, igualmente arriscada e desestabilizadora, como 
bem o postula Haraway, por tratar mais com questões do que com respostas, por buscar nas próprias narrativas aquilo que é importante perguntar.

Quem narra alguma coisa está contando uma história, independentemente do meio que utiliza para fazê-lo: pode ser uma narrativa oral, escrita, cinematográfica ou pictórica. Tradicionalmente, a narrativa é considerada como a expressão de um comportamento humano que é ao mesmo tempo imitativo e representativo, serve à comunicação entre as pessoas e veicula sentidos, entendidos aqui como significação ou significado não cristalizado, mas também como algo que implica intencionalidade e finalidade (Cardoso, 1997).

Devido ao interesse em analisar e compreender a realidade, considerando-a como algo que é dependente da interpretação humana, acessada por meio dos conteúdos explícito e implícito das narrativas sobre SD, optou-se por situar a análise das fontes no âmbito da semiótica, um campo que envolve diferentes perspectivas teóricas e ferramentas metodológicas e que pode ser definido de forma ampla como o estudo dos signos.

Para o filósofo americano Charles Sanders Peirce (2003: 46), um signo é "aquilo que, sob certo aspecto ou modo, representa algo para alguém". Signos englobam palavras, imagens, sons, objetos, atitudes, enfim, qualquer elemento que, apesar de não possuir significado em si, possa ser investido de significado por alguém (Chandler, 2007).

Para Peirce (2003), o modelo de signo é triádico, consistindo num representâmen, que é a forma (não necessariamente material) que o signo toma, isto é, aquilo que representa algo para alguém; um 'interpretante', que é o signo que foi criado na mente desse alguém a partir do representâmen; e o 'objeto' ou 'referente', aquilo no lugar do qual o signo está. Logo, para ser considerado um signo, os três elementos devem estar presentes: aquilo que é representado, como ele é representado e como ele é interpretado por alguém. De acordo com a forma de relação estabelecida entre o representâmen e o interpretante, os signos podem ser índices (quando existe uma conexão direta entre os dois), ícones (quando ambos se assemelham) ou símbolos (quando a relação é baseada numa convenção). 
Em semiótica, nada é completamente neutro, sendo impossível representar algo exatamente como é. O uso da linguagem vai além do simples nomear de coisas, as quais não são independentes dos sistemas de signos usados pelos grupos humanos. Palavras são abstrações, e nem todas correspondem a objetos materiais no mundo. Conforme aponta Michel Foucault (2002), a partir do século XVII rompe-se o parentesco por similitude, a conexão considerada como 'natural' entre as palavras e as coisas: as palavras deixam de ser os nomes das coisas para ser sua representação.

O famoso quadro do pintor surrealista belga René Magritte La Trahison des Images [A Traição das Imagens], de 1926, o qual mostra uma representação de um cachimbo visto de lado e, abaixo dele, a inscrição Ceci n'est pas une pipe [Este não é um cachimbo], ilustra a noção de que qualquer representação é mais do que uma simples reprodução daquilo que pretende representar, e que contribui em certo sentido para a construção da realidade (Foucault, 1983). Tal como as palavras são representações, também as imagens não podem ser confundidas com o objeto ao qual se referem. Dito de outra forma, a presença da imagem afirma a ausência do objeto ao qual alude.

Ao se analisarem as relações estruturais subjacentes a textos e práticas culturais, cabe ressaltar a importância de não se subestimarem os sistemas sociais que as sustentam. Não se trata de considerar apenas a relação entre os elementos de um texto, mas também os significados atribuídos pelos leitores aos signos nele presentes.

Significados não são dados ou transmitidos de forma pronta, mas criados em consonância com as inter-relações existentes entre os códigos e as convenções de um grupo, muitas vezes despercebidos pelos seus membros. O processo de explicitar de que maneira os signos são interpretados, e dentro de que sistema de códigos, permite contestar aspectos da realidade tidos como 'naturais' e entender o sentido de sua existência.

O uso de tropos contribui para tornar o estranho familiar; o uso repetido de determinadas figuras de linguagem traduz um acordo subliminar que se faz como membro de um grupo, no qual determinadas 
afirmações são compartilhadas e entendidas como verdadeiras. Imagens comunicam pelos elementos nelas presentes (ou ausentes) e pela relação entre eles e, principalmente, são percebidas de acordo com a perspectiva daquele que observa, não podendo seu conteúdo simplesmente ser assumido como universal.

A fotografia, em especial, suscita um velho e inesgotável debate sobre o quanto ela é uma fiel reprodução do 'real'. Em primeiro lugar, está o fato de que a fotografia é uma representação bidimensional de um mundo que é tridimensional - o que por si só já destitui o caráter de fidelidade ao real. Em segundo lugar, sabe-se que qualquer fotografia resulta de uma série de opções feitas pelo fotógrafo no momento em que fotografa, como composição, enquadramento e iluminação, por exemplo, e outras tantas opções feitas após o disparo e que dizem respeito à edição da imagem, obtida tradicional ou digitalmente, como corte, ajuste de contraste e balanço de cor, só para citar algumas.

Toda imagem carrega em si uma mensagem conotativa, não apenas por todo o seu processamento, mas também por se referir a como a sociedade, na qual essa imagem circula, entende e comunica determinado aspecto da realidade. Entretanto, nem sempre a conotação é clara e explícita; ela pode ser apreendida nos fenômenos que envolvem a produção e a recepção da mensagem (Barthes, 1977). Implícitas a cada imagem, outras ainda se escondem, numa rede de analogias, correspondências e confrontações. Contudo, a forma como determinadas imagens são conectadas a significados particulares para veicular mensagens específicas, delas extraindo-se o seu conteúdo histórico e contextual, constitui um fenômeno social que Roland Barthes (2001) definiu como a criação de um mito, e que traduz formas de pensar sobre pessoas, ideias, produtos ou lugares. Não é o objeto em si que se torna mito, mas o modo como é proferido. O fato de a fotografia ser uma reprodução, capturada mecanicamente, daquilo que se encontra em frente à câmera leva a crer que ela não está sujeita a nenhum tipo de código. Contudo, tal fato revela-se como um de seus aspectos míticos e serve de base para a atuação de códigos culturais na produção de significados. 
As sequências exibidas em filmes pautam-se por códigos cinematográficos compartilhados pelo cineasta e pela audiência, os quais ditam a forma como os signos (gráficos, sonoros, fotográficos e linguísticos) são combinados e utilizados para gerar significados (Bignell, 2002). Segundo Umberto Eco (1979), os sistemas de códigos, necessários ao processo de significação das imagens, não estabelecem significados específicos para cada elemento de um texto, mas sim as bases para a compreensão de todo o processo textual. A decodificação dos signos por parte do espectador é um processo ativo; assim, os significados são construídos não pela leitura de um significado específico que se apresenta 'pronto' no texto, mas por meio de uma verificação e de um ajuste contínuos desses códigos por parte do espectador.

Reportagens não são apenas fatos, mas representações da realidade produzidas com a utilização de diferentes tipos de signos, como os linguísticos e os visuais, por profissionais com determinada orientação de pensamento, composição e escrita para cada tipo de discurso da mídia impressa. As conotações incorporadas a tais signos moldam significados por meio de códigos jornalísticos que o leitor reconhece como familiares. O que se entende por jornalismo científico, ao qual se costuma associar qualidades como neutralidade, objetividade e verdade, também é submetido aos mesmos códigos e resulta de um processo que nada tem de 'natural' ou puramente denotativo.

Por conseguinte, ao se analisarem imagens apresentadas em campanhas, filmes, livros, blogs ou reportagens, entende-se que elas não são meramente apêndices do texto, mas dotadas de autonomia estrutural sem ser, contudo, dele dissociadas. Palavras, no caso do texto, e linhas, sombras e superfícies, no caso das imagens (individuais ou sequências), compõem substâncias diferentes (Barthes, 1977, 2003) que são analisadas em separado e, a seguir, de forma complementar.

As fontes analisadas referem-se à produção cultural sobre SD voltada para o público em geral. Delas foram excluídas aquelas produzidas no círculo biomédico e endereçadas ao público especializado, apesar de também se constituírem como produtos da cultura. ${ }^{1}$ Não se pretendeu 
esgotar tal repertório, mas trabalhar com o que se apresentou como relevante, narrativa sugerindo narrativa, numa sequência de indícios capturados ao longo do trajeto. Essas fontes são descritas a seguir, organizadas em três grupos principais.

O primeiro grupo é composto por imagens plurais, narrativas que estavam em evidência na mídia impressa e televisiva, em publicações voltadas para o público em geral e no cinema durante o curso da pesquisa. $\mathrm{O}$ slogan "Ser diferente é normal", das campanhas publicitárias criadas pela agência de publicidade Giovanni FCB para o Instituto MetaSocial e veiculadas em 2003, 2004, 2005 e 2008, teve grande repercussão e transformou a SD em símbolo do movimento de inclusão da diversidade humana. É analisado com a fotografia a ele associada em 2003 e 2004, por ser esse momento um importante marco na atuação do instituto em termos de ampliação do seu alcance. O Instituto MetaSocial é uma organização não governamental sem fins lucrativos, criado por um grupo de pais e amigos e formalizado em 2004, visando à inclusão de pessoas com deficiência. Trabalha com projetos ligados à informação, tendo participado de diversas campanhas veiculadas pela mídia com o objetivo de informar sobre potencialidades e capacidades dessas pessoas.

A pintura de Andrea Mantegna (1431-1506) que representa a Virgem com o Menino Jesus, Madonna col Bambino, é conhecida e assumida como representando uma criança com SD, tanto no círculo biomédico quanto no não especializado, sendo divulgada em livros, sites e blogs em diversos idiomas, com disseminação dos significados por ela sugeridos. O pintor renascentista, extremamente minucioso no tocante à representação do que via, teve algumas de suas obras estudadas em razão da sua possível relação com a SD (Stratford, 1982, 1996; Schwartzman, 1999; Cardoso, 2000; Pueschel, 2005). Pintor oficial da poderosa família Gonzaga de Mantua, Mantegna foi um dos primeiros artistas a utilizar modelos vivos para suas pinturas. Tais estudos sugerem que os modelos usados nesse quadro são uma criança e sua mãe, Barbara di Brandeburgo, da família de seu patrono, ou a própria esposa de Mantegna, ou uma de suas amantes e seu filho. Segundo foi investigado, as duas crianças tinham a mesma doença, e os 
sinais descritos apontam para a SD; nesse quadro observa-se, principalmente, a hipotonia do bebê e o bócio na mulher, indicando uma disfunção da tireoide, por muito tempo associada às crianças afetadas.

O documentário brasileiro de 2004 Do Luto à Luta, com roteiro e direção de Evaldo Mocarzel e produzido por Casa Azul Produções Artísticas e Circuito Espaço de Cinema, foi exibido no $2^{\circ}$ Festival Internacional de Filmes sobre Deficiência Assim Vivemos, patrocinado pelo Centro Cultural Banco do Brasil (CCBB), edição 2005. Ganhou o Prêmio Especial do Júri no Festival de Gramado, o de Melhor Documentário - Júri Popular no Festival do Rio - e mais sete prêmios no Cine PE, em 2005. O filme conta a história de várias famílias, entre elas a do próprio diretor, e o processo vivido por elas a partir do diagnóstico de SD até o presente. Dele foi retirada uma imagem utilizada na capa do vídeo e na sua divulgação, representando um casal com SD, e que resume um dos principais questionamentos sobre o futuro dessas pessoas. Por ocasião do lançamento do filme, o diretor e o casal foram entrevistados pela jornalista Marília Gabriela em seu programa Marília Gabriela Entrevista, no canal por assinatura GNT/Globosat. Uma pergunta feita pela entrevistadora foi escolhida para análise por se conectar à narrativa anterior.

O segundo grupo é composto por 164 narrativas na forma de relatos em livros, coletivos e individuais, e 352 na forma de blogs de acesso livre, escritos e produzidos por pais de pessoas com SD, nos idiomas português, inglês e espanhol.

A princípio, intencionava-se centrar a análise nas fontes extraídas do panorama brasileiro. Entretanto, dois fatores foram decisivos na modificação da ideia inicial: o primeiro deles, o número restrito de livros produzidos no Brasil, despertando a curiosidade com relação a essa produção em outros países para comparar significados. O segundo refere-se à falta de restrição espacial proporcionada pela Internet, eliminando distâncias e exacerbando a proximidade temporal das narrativas. Disso resulta a demarcação de um território que não é da ordem do geográfico, mas da identidade biológica, o território da SD. Em muitos blogs, a completa ausência de 'enraizamento' levou a uma leitura dos sinais que dessem pistas sobre 
esse dado, uma vez que era de interesse localizar as narrativas para analisálas, a fim de não se desprezarem possíveis diferenças culturais.

As publicações, selecionadas por meio de busca on-line nas livrarias virtuais Cultura e Amazon, são majoritariamente dos Estados Unidos, sendo que oito narrativas na forma de livro foram produzidas no Brasil e apenas uma na Espanha. Se comparada à dos Estados Unidos, a publicação nacional é escassa, bem como é escasso o contato da maioria das pessoas com o material publicado.

Os blogs foram selecionados com base na busca on-line e por meio das indicações presentes em cada um deles, compondo uma espécie de rede. Foram acessados entre novembro de 2008 e março de 2009. Incluem produções dos Estados Unidos (a maioria), Brasil, Chile, Colômbia, Costa Rica, Argentina, Guatemala, Canadá, Espanha, Áustria, Reino Unido, Irlanda, África do Sul, Austrália, Arábia Saudita e Israel. Os blogs brasileiros organizados em grupos fechados, como grupos de discussão aos quais só se tem acesso mediante inscrição e que constituem maioria, não foram considerados na análise. Esse tipo de organização, na qual as trocas de experiências são restritas a um território específico, se por um lado cria um ambiente protegido e controlado para recontar histórias consideradas difíceis e remodelar identidades, por outro 'destaca' o território da SD no sentido etimológico apresentado pelo Dicionário Houaiss (Houaiss, Villar \& Mello Franco, 2004: 1.017), cuja origem remonta ao latim destaccare (retirar, separar).

A realidade apresentada nos blogs produzidos nos Estados Unidos é bastante diversa da que se observa em países como o Brasil, onde tais pessoas dependem quase que exclusivamente de suas famílias (particularmente os pais), e o acesso a trabalhos diferenciados que auxiliem no seu desenvolvimento é restrito a uma minoria. A sociedade americana valoriza enormemente ações comunitárias: um grande número de instituições financia a publicação de livros sobre a questão da deficiência, não apenas a SD, além de oferecer uma extensa rede de apoio a essas pessoas. ${ }^{2} \mathrm{O}$ aprendizado da linguagem de sinais é parte fundamental desse processo, criando canais de expressão para as crianças com SD, antes mesmo de elas 
conseguirem se expressar verbalmente. Assim, ações práticas possibilitam uma vida mais plena e independente da família, mas com relativo suporte.

Livros e blogs compõem diferentes tecnologias de comunicação que veiculam narrativas em que a ênfase é dada, respectivamente, ao relato escrito e ao relato multimodal, o qual pode incluir textos escritos, imagens fixas ou em movimento, sons, elementos das narrativas orais e, especialmente, interatividade.

Os livros escritos por pais de pessoas com SD tratam, em primeiro lugar, de registros de memória, feitos em tom confessional, como forma de elaborar o fato de se ter um filho com essa condição por meio do compartilhar da experiência, ou ainda de tornar pública a vida de alguém que tem SD, num processo de (re)delineamento e abertura do self (Foucault, 2003a). Em segundo lugar, sugerem imagens e carreiam significados relativos a uma condição geneticamente determinada pela presença de um cromossomo 21 extra e, mais amplamente, à genética e seus avanços tecnológicos.

Os weblogs ou apenas blogs despontaram nos anos 90 e constituem um nome genérico que compreende várias formas de interação acessadas via Internet, dentre elas os lifelogs, versão digital mais próxima dos antigos diários e que são aqui enfocados; os photoblogs, nos quais fotografias são adicionadas ao texto, que perde parte de sua importância; os linklogs, diferentes dos primeiros por permitir a postagem de links a outros websites sem a inclusão de detalhes da vida pessoal do indivíduo, ou blogueiro (blogger) na linguagem digital (Schaap, 2004). Blogs, mais do que ferramentas tecnológicas para preservar memórias visando a uma revisitação futura, voltam-se para o compartilhar de experiências ${ }^{3}$ não mais num âmbito privado restrito, mas direcionados a um público mais amplo, em grande medida anônimo, possibilitando a (re)construção do self por meio das experiências de outros (Van Dijck, 2007).

Por fim, o terceiro grupo de narrativas abarca reportagens sobre SD veiculadas entre janeiro de 2000 (ano em que o cromossomo 21 foi mapeado) e março de 2009 na revista semanal de maior circulação no país, Veja, publicada pela Editora Abril, e que aborda temas do cotidiano da 
sociedade brasileira, como política, economia, ciência, cultura e comportamento, e também temas mundiais, como guerras e conflitos diplomáticos; e no jornal $O$ Globo, de alcance nacional (apesar de sediado no Rio de Janeiro), que pertence às Organizações Globo. Tanto os leitores da Veja quanto os de $O$ Globo pertencem majoritariamente às classes $\mathrm{A}$ e $\mathrm{B}$, com escolaridade superior. As narrativas foram selecionadas pela busca on-line mediante a palavra-chave 'síndrome de Down', perfazendo um total de 158 ocorrências (48 na Veja e 110 em O Globo).

Com o intuito de apreender os sentidos e as imagens presentes nas narrativas escritas e iconográficas sobre SD em todas as suas sutilezas, priorizou-se o material implícito que é manifesto nos detalhes, nos gestos, nas reticências, nos silêncios, em detrimento do que é explícito, aparente. O interesse pelo indiciário ancora-se no modelo, de características semióticas, proposto pelo historiador Carlo Ginzburg (2001a, 2004), tendo por base o método desenvolvido pelo crítico de arte Giovanni Morelli, no século XIX, para identificar a verdadeira autoria de determinadas pinturas e diferenciá-las daquelas fraudulentas. Essa diferenciação se faria não em razão das características mais marcantes de determinado artista, concernentes a estilo ou escola, mas sim da sua marca autoral deixada na execução de pequenos e sutis detalhes, tais como dobras de tecido, orelhas, volteios dos cabelos, unhas.

O contato com o tema veiculado nas narrativas demandou uma atitude de 'estranhamento' (Ginzburg, 2001b), a fim de percebê-lo como se pela primeira vez, com distanciamento crítico, sem se deixar levar por interpretações e significados preestabelecidos e questionando tudo aquilo que se apresentava como 'natural' em relação à SD e às pessoas que com ela nascem.

A narrativa é um tipo de discurso que se define como figurativo por comportar personagens que realizam ações e por ser contextualizada espacial e temporalmente. O discurso organiza-se em dois níveis de profundidade, o das estruturas superficiais ou discursivas, que fala da maneira como a narrativa é contada, e o das estruturas profundas ou semionarrativas, que diz respeito ao sentido do que é contado. 
Consideraram-se como textos, e como tais passíveis de análise, as narrativas que se apresentaram como enunciados verbais (orais e escritos) ou não verbais (filmes, quadros, fotografias), com características de autonomia e dotados de significação e função integrais. Definir algo como um texto envolve a observação de determinados aspectos, como a coerência textual, que é aquilo que une as frases, no caso de textos verbais, ou os planos, no caso de textos imagéticos, caracterizando-os como partes de um todo mais abrangente. De acordo com a perspectiva do leitor/ouvinte, a coerência do texto diz respeito às competências textual e intertextual que permitem que ele, no caso da primeira, perceba as frases como fragmentos interligados de um todo, mesmo quando suas conexões estão implícitas, sendo capaz de supri-las quando necessário; e no caso da segunda, que possa lançar mão de experiências anteriores com outros textos para poder contextualizar o atual.

Estabelecidos os marcos referenciais, seguiram-se determinados procedimentos na análise do material coletado. Após a leitura exaustiva das narrativas, tanto escritas quanto iconográficas, encetou-se o exame comparativo de frases e enunciados, ou seja, das partes que compõem um texto, no sentido de identificar as categorias sêmicas presentes. As categorias sêmicas comportam semas e antissemas, entre os quais existe uma relação de disjunção, uma vez que eles são opostos, mas também de conjunção, pelo fato de pertencerem a uma mesma totalidade de sentido, um mesmo eixo semântico que os engloba.

A seguir, identificaram-se, dentre as categorias sêmicas, aquelas que se repetiam no texto, constituindo as categorias isotópicas. Por fim, distribuíram-se as categorias isotópicas encontradas em três níveis semânticos - o figurativo, o temático e o axiológico. O figurativo refere-se a significados apreendidos diretamente pelos sentidos, ligando-os à percepção do mundo real; o temático, a elementos abstratos que serão expressos pelos elementos figurativos (por exemplo: o cuidado é um elemento temático, enquanto o preparar o alimento para uma criança doente é figurativo); o terceiro nível, o axiológico, relaciona-se a algum sistema de valores que pode estar manifesto nos conteúdos do texto, e que valoriza 
eufórica ou disforicamente determinados conceitos (por exemplo, belo e feio, de acordo com um padrão).

Tais procedimentos constituem uma adaptação do método de leitura isotópica desenvolvido por Algirdas Julien Greimas (1987). O seu uso permite a passagem do que seria a significação que se encontra em cada frase ou enunciado tomado isoladamente, denominada microssemântica, para a busca da significação do discurso completo, observado em termos transfrasais, a macrossemântica.

A observação das categorias isotópicas produz uma grade de leitura que pode ser expressa graficamente por meio do quadrado semiótico, que resume a principal estrutura profunda de significação presente no texto completo. Aplica-se essa operação semiótica em algumas narrativas, como técnica analítica complementar, não para demarcar posições rígidas e literais, mas sim pela possibilidade de salientar a dinâmica de relação entre dois termos isotópicos numa determinada categoria e descortinar uma ampla gama de significados entre eles, transpondo uma oposição lógica binária. O arranjo dos termos no quadrado coloca-os sob tensão, de forma a sustentar ou não a hipótese que os posiciona num mesmo eixo semântico.

A produção de fatos científicos é um processo que envolve a construção de imagens e de elementos imaginativos que facilitam a circulação do conhecimento, por clarificar o que seriam conceitos abstratos (Van Dijck, 1998). As fronteiras entre os círculos biomédico e o não especializado são permeáveis, uma vez que ambos se encontram no âmbito da cultura, e as imagens e a imaginação tornam-se significativas porque mobilizam apelos com conteúdo dramático para tal grupo cultural.

A presença de uma condição genética espacializa e revela esse intrínseco e dinâmico entrelaçamento e solicita constantes movimentos de reconfiguração no sentido de incorporar conhecimentos, torná-los significativos e acomodá-los à perspectiva de vida de um indivíduo ou família específicos. Ao mesmo tempo, provoca reflexões sobre a responsabilidade envolvida e os possíveis desenlaces futuros. 
É possível acompanhar esses movimentos, uma vez que eles são plasmados nas narrativas produzidas individual ou coletivamente num espaço-tempo, descortinar imagens, elementos imaginativos e significados e compreender como foram apropriados, transformados, pronunciados e difundidos. É disso que trata a fuga que se apresenta a seguir.

NOTAS

1 Estas foram consultadas a fim de traçar o breve histórico do percurso científico das pesquisas sobre SD apresentado na 'Exposição', sem, entretanto, serem submetidas aos critérios analíticos aplicados às outras fontes.

2 Tal rede de apoio inclui associações locais criadas por pais de pessoas com SD, as quais oferecem contatos com outros pais, palestras e material informativo, agências de empregos, financiamento de concursos e premiações, residências onde vivem quatro ou cinco pessoas com algum tipo de deficiência acompanhadas de uma outra que administra a casa. Ao mesmo tempo, um ato governamental sobre adoção publicado em 1980, The Adoption Assistance and Child Welfare Act of 1980 (United States of America, 1980), passou a oferecer subsídios a pais que desejassem adotar uma criança, com valores adicionais caso fosse uma criança com alguma das deficiências listadas no ato, dentre as quais a SD. Diversas narrativas em blogs abordam processos de adoção, muitos dos quais em famílias nas quais já existe um membro com SD, e trazem links para organizações responsáveis por encontrar lares para essas crianças. Vários desses processos tornam-se possíveis graças a um extenso suporte também de particulares, feito por meio de doações.

3 Nesse sentido, observa-se uma certa volatilidade nos blogs, pois ao tentar reacessá-los, vários deles tinham mudado de nome ou haviam sido desativados, tornando impossível a sua relocalização. 


\section{EXPOSICÃO}

Time present and time past Are both perhaps present in time future And time future contained in time past.

If time is eternally present All time is unredeemable.

What might have been is an abstraction Remaining a perpetual possibility

Only in a world of speculation.

What might have been and what has been Point to one end, which is always present.

Footfalls echo in the memory Down the passage which we did not take Towards the door we never opened...

T. S. Eliot ("Burnt Norton", 1969: 171)1

"Um cobertor. Vários estados. Vários países. Centenas de famílias. Um fio comum!"2 Esta é a mensagem que introduz o projeto The T21 Traveling Afghan, ${ }^{3}$ um projeto idealizado pela mãe de uma criança com síndrome de Down (SD) e que tem mobilizado dezenas de famílias nos Estados Unidos e em vários outros países, tanto no ciberespaço quanto no mundo dito real, ambos entendidos como diferentes modalidades espaço-temporais, compostas por processos e práticas materiais-semióticas e elementos literais e figurativos (Haraway, 1997). 
O propósito desse projeto, segundo sua idealizadora, é conectar as famílias que compartilham 'diferenças', entenda-se aqui SD, e celebrálas. Um pequena manta (afghan) por ela tricotada viaja de casa em casa como um símbolo, selando o compromisso de pertencimento à comunidade trissomia do 21, ao mesmo tempo que literal e metaforicamente agasalha e acolhe cada uma dessas pessoas. Permanece algum tempo em cada casa, o suficiente para ser incluída na rotina da família e serem feitos registros fotográficos da ocasião, os quais são enviados para a iniciadora do projeto, que se encarrega de divulgá-los. A família, então, escreve uma nota num diário que acompanha a manta, a qual retoma sua viagem com destino a outra família que tenha entre seus membros alguém com SD.

Eventos dessa natureza nascem e proliferam no espaço virtual da Internet, unindo pessoas que têm algo em comum: uma condição biológica específica que as configura primordialmente como indivíduos somáticos e as agrupa numa rede de relações que transcende os laços de sangue ou de nação.

O fortalecimento desses vínculos se faz por meio de práticas confessionais, consideradas como tecnologias do self (Foucault, 2003a), manifestas em livros, blogs e salas de conversa na Internet, e envolvem um processo de abertura no qual o self é exposto, narrado e redefinido em termos de uma identidade que, no caso da SD, é calcada num aspecto genético.

Essa nova configuração é um dos elementos importantes resultante dos avanços da biomedicina - marcadamente, da mudança para um estilo de pensamento (Fleck, 1981) molecular, que contribui para a (re)definição do conceito de pessoa, alterando a forma como os corpos são entendidos e conceitualizados. As identidades passam a ser moduladas com base em elementos de uma corporalidade, afetando profundamente as relações sociais e abarcando outras manifestações humanas na moldura biomédica.

A formação de grupos em torno de uma condição biológica definida pela biomedicina, com suas narrativas e um sem-número de especialistas que os ajudem a experienciar e entender tal condição e atuar sobre ela, a qual Paul Rabinow (1992) denominou biossocialidade, não é um evento 
novo; mas as conformações que esses agrupamentos assumiram na era genômica apresentam algumas particularidades: um aspecto informacional, que se traduz na disponibilidade de conhecimentos especializados antes restritos ao domínio do profissional médico; um aspecto de reivindicação de um lugar na sociedade e de direitos por melhores condições de acesso a testes e terapêuticas específicas; e um novo elemento, um aspecto digital, que se refere à criação de comunidades virtuais, unidas eletronicamente e que disseminam verdades plurais, as quais passam a coexistir com as anteriormente hegemônicas (Rose, 2007). No caso de inúmeras condições, esses grupos desenvolvem alianças diretamente com especialistas a fim de participar das etapas - e muitas vezes financiá-las - na busca por novos medicamentos, novos tratamentos e cura. No Brasil, esses grupos se desenvolvem a partir do final da década de 1980 .

A organização de grupos e a participação do público em pesquisa constituem o que Regula Burri e Joseph Dumit (2007) denominam como movimento de 'socialização da biomedicina', no qual é prevalente o modelo de 'parceria' entre cientistas e o público leigo, cujas relações refletem novas formas de interação entre ciência e sociedade. ${ }^{4}$

A preocupação crescente com o modo como as relações entre ciência e sociedade são estabelecidas, entendidas e administradas tem motivado pesquisas, como a financiada pela Wellcome Trust no Reino Unido (Burchell, Franklin \& Holden, 2009), cujos focos são o engajamento do público em ciência e o diálogo daí resultante, considerados elementos-chave para inovação e pesquisa científicas. O modelo unilateral que considera o público em geral 'deficiente' em conhecimento, devendo ser informado ou 'educado' sobre os avanços científicos, tem sido paulatinamente substituído por outro que reconhece e valoriza a existência de um tipo de conhecimento diferente do especializado, por isso mesmo importante, e que se configura como um modelo de dupla via no qual aspectos como diálogo, deliberação e parceria são fundamentais.

Eventos como o descrito no início desta Exposição constituem práticas levadas a cabo dentro da moldura da política vital que é exercida no século XXI. Ainda que a preocupação política com aspectos relacionados à 
saúde da população não seja recente, esta ganha novos contornos em meados do século XX, com a descoberta da estrutura de dupla hélice do DNA $(\mathrm{ADN} \text { - ácido desoxirribonucleico })^{5} \mathrm{e}$, posteriormente, com o desenvolvimento de técnicas para sua manipulação, introduzindo modificações fundamentais no entendimento dos processos vitais.

Em breve recapitulação, o poder sobre a vida que se desenvolve a partir do século XVII e que, diferentemente daquele exercido nas sociedades pré-modernas, tem como papel primordial garanti-la, sustentá-la e ordená-la, apoia-se em dois pilares complementares entre si: o da disciplina dos corpos, voltada para a sua otimização e o seu desempenho, e o das regulações da população, por meio de intervenção e controle sobre os processos vitais do corpo como espécie. O segundo pilar, apesar de se voltar para a população como coletivo, apresenta também um caráter particularizante, que localiza o indivíduo no grupo ao qual pertence, articulando ambas as tendências. Esse poder, a que Foucault (2003b) denomina biopoder, e o investimento que por meio dele se faz nos corpos vivos são de fundamental importância para o desenvolvimento do capitalismo e representa a entrada dos fenômenos vitais humanos na esfera das técnicas políticas, tornando-se uma biopolítica: "o homem moderno é um animal, em cuja política, sua vida de ser vivo está em questão" (Foucault, 2003b: 134). Daí resulta uma sociedade normalizadora e disciplinar, que mede, avalia, quantifica e regula em nome do bem-estar da população e que gera como resposta as lutas pelo direito à vida, ao corpo e à satisfação das necessidades como caminho para se chegar à expressão do que se é e do que se pode chegar a ser.

De acordo com Gilles Deleuze (1992), assim como as sociedades soberanas foram substituídas pelas sociedades disciplinares dos séculos XVIII e XIX, cujo apogeu se localiza no começo do XX, novas forças foram gradualmente se instituindo, em especial após a Segunda Guerra Mundial, levando a um processo de substituição das sociedades disciplinares por outras nas quais o controle é parte integral, modulando atividades e práticas de existência. Segundo o autor, essa situação não é para ser ansiada ou temida, mas a questão relevante é encontrar novas armas para com ela se lidar. 
Para Paul Rabinow e Nikolas Rose (2006), a expressão biopoder inclui um ou mais discursos de verdade definidores do que são os seres humanos em seu aspecto vital, pronunciados por autoridades estabelecidas como competentes para tanto, estratégias de intervenção em nome da saúde e da vida e formas de subjetivação, por meio das quais os indivíduos atuam sobre si mesmos, sobre sua saúde, imbuídos desses mesmos discursos de verdade. A presença do controle pode ser observada na constante exigência aos indivíduos de monitorar e administrar suas capacidades como cidadãos biológicos (Rose, 2007).

Na biopolítica contemporânea que tem lugar nas chamadas democracias liberais avançadas ocidentais, isto é, naquelas em que o Estado sofreu uma retração, tendo seus limites redefinidos, e com diferentes noção de liberdade e mecanismos de segurança (Miller \& Rose, 2008a; Lentzos \& Rose, 2009), novas formas de biopoder - ou tecnobiopoder, para usar a expressão adotada por Haraway (1997) - são exercidas nas intervenções sobre a vitalidade humana, agora no nível molecular. Rose (2007) sugere que a biopolítica da vida ou política da 'vida em si' (life itself), de acordo com o olhar molecular através do qual ela é entendida, sofreu uma alteração tornando-se uma 'ethopolítica'.

Essa mudança reflete a valorização de uma gama de diferenças entre formas de ser humano, estilos de vida e modos de viver que devem ser escolhidas e conduzidas num cenário de incerteza em que convivem lado a lado interesses econômicos, demandas clínicas e reivindicações por tratamento e direito à saúde por parte de pacientes e familiares. E, principalmente, torna-se 'ethopolítica' pelas novas tecnologias do self, por meio das quais os seres humanos se pensam a si mesmos, fazendo uso do discurso biomédico, e devem ser capazes de escolher por si próprios, de acordo com seu julgamento, formas de se aprimorarem e de se tornarem melhores do que são hoje.

O poder pastoral, descrito por Foucault (2003c), ${ }^{6}$ ganha nova roupagem na biopolítica contemporânea, com perda de seu caráter de unilateralidade e necessidade de obediência e passividade por parte do 'rebanho', e deixando de ser organizado e administrado pelo Estado. Torna-se 
relacional, forjado nos encontros entre profissionais, pacientes e seus familiares. Mobiliza aspectos éticos relativos ao cuidado e às formas de governar condutas, ao colocar em foco os limites individuais de responsabilidade consigo mesmo e com os outros. Associados às diversas especialidades emergentes, os 'novos pastores do soma', em suas funções de cuidado e suporte, como o aconselhamento genético, por exemplo, ampliam seu domínio da situação de doença e cura para a de administração da vida, apoiando-se em princípios éticos de autonomia, consentimento informado e escolha, e envolvendo subjetividades e tecnologias de informação e comunicação (Rose, 2007).

A atualização feita por Haraway (1997) da expressão foucaultiana atesta a presença significativa da biotecnologia como estratégia de intervenção nos corpos e demarca outro modo de espaço-tempo, caracterizado por um espaço globalizado e uma temporalidade indicada por condensação e fusão, na qual a implosão das fronteiras entre o técnico e o orgânico, o político e o econômico, o natural e o artificial, produz novos desenhos de significados com suas faces literal e figurada.

Biotecnologia e globalização estão intrinsecamente interligadas. A indústria biotecnológica floresceu e continuou se expandindo alicerçada em agenciamentos globais. Da mesma forma, outros fenômenos biológicos têm hoje alcance globalizado, não apenas em termos de efeitos e implicações decisórias, como por exemplo na recente pandemia de gripe do tipo influenza A (H1N1), mas também de divulgação em mídia e outras produções culturais que mostram as tentativas dos seres humanos de entender e assimilar determinados eventos passados ou possíveis no futuro e reagir a eles (Thacker, 2006).

Trocas biológicas são rotineiramente levadas a cabo por meio de tecnologias nas redes compostas por corpos e materiais biológicos diversos, como nas transfusões de sangue ou na doação de gametas para reprodução assistida ou pesquisa, por exemplo, e intermediadas pelos sistemas médico, técnico e jurídico (Thacker, 2006). A regulação de tais trocas busca garantir que cada um dos elementos envolvidos nessas relações seja beneficiado; entretanto, esse fato não é isento de conflitos. Apesar de a 
noção de troca biológica ser antiga, como na agricultura ou na criação de rebanhos, o que está em pauta agora é a circulação e a transposição de um corpo a outro da 'vida em si', informação biológica em termos materiais ou imateriais que circula interativamente (Thacker, 2006), como por exemplo DNA, células e tecidos, os quais se tornam mercadorias comercializáveis como produtos.

Além de constituírem informação biológica, construtos como os genes podem ser considerados 'nós relacionais' no meio tecnobiocientífico, metaforicamente entendido como corpo, equivalentes a células-tronco ${ }^{7}$ que trazem consigo múltiplas possibilidades de diferenciação, e que estão presentes na cultura, tanto nas práticas de produção de conhecimento como nas histórias dos corpos (Haraway, 1997). Ao mesmo tempo que pertencem ao domínio que se poderia chamar 'intransitivo', ou seja, um domínio ontológico que independe da ação humana, os genes encontram-se também no domínio 'transitivo', uma vez que se conformam como objetos de conhecimento em vários discursos (Amigoni, 2008).

No discurso não científico, genes conciliam esferas contraditórias de significados, revelando-se invisíveis em sua visibilidade orgânica, abstratos em sua concretude de traduzir uma existência somática, conjecturais em sua tangibilidade, ao mesmo tempo pertencentes ao indivíduo e à esfera dos dados estatísticos na forma de riscos. Aglutinam passado, presente e futuro, um passado familiar, um presente somático e expectativas futuras baseadas ora na experiência e na observação, ora no domínio da probabilidade (Duden \& Samerski, 2007). Determinadas imagens metafóricas apresentam os genes como responsáveis por transmitir as mensagens do destino, numa equivalência ao deus grego Hermes, ou Mercúrio na mitologia romana, sempre transitando entre os domínios do divino e as questões humanas.

Ao ser pronunciado no discurso coloquial, o termo gene apresentase dotado de uma característica reflexiva, ou seja, refere-se àquele que fala, ao mesmo tempo que funciona como índice, apontando para algo que é fundamentalmente corpóreo na pessoa. Tais características resumem um poder capaz de qualificar o soma como sendo composto por genes. 
O DNA, mais do que uma entidade molecular, tornou-se um ícone cultural, uma sinédoque representativa da vida, cuja definição no discurso coloquial é muitas vezes intercambiável com a de gene (Roof, 2007), uma mercadoria comercializável usada para vender outros produtos, tais como carros, livros, cosméticos, filmes e outras produções artísticas. O poder que lhe foi atribuído por cientistas e pelo público em geral reforçou imagens relacionadas à esfera do sagrado e, consequentemente, aos perigos decorrentes de sua manipulação (Nelkin \& Lindee, 2004).

Nos anos 50, com a difusão da teoria da comunicação, dos computadores, das tecnologias de simulação e comunicação, mudanças ocorreram nas noções de texto, mensagem e linguagem, tornando pertinente a nomeação de moléculas e organismos como textos, depositários de informação e sistemas de transferência. A hereditariedade passou a ser entendida, então, como um sistema programado de comunicação regido por um código que se encarregaria de transferir 'informação linguística' através das células, pelos ciclos de vida (Kay, 2000).

Esse tipo de imagem encontrava-se subjacente ao desenvolvimento do Projeto Genoma Humano ${ }^{8}$ nos anos 90 e se articulava a metáforas de criação, vinculadas a um padrão particular de linguagem da tradição judaico-cristã (Haraway, 1997; Franklin, 2000; Nelkin, 2004). A metáfora do 'livro da vida' - e sua variante, o 'livro da natureza' - é muito antiga, permeando a sociedade judaico-cristã através da religião, mas foi atualizada e legitimada cientificamente pelo discurso da informação. A associação dessa imagem ao código genético ${ }^{9}$ representou a literalização da metáfora, o entendimento dele como escrita universal, eterna e natural, não levando em consideração as possíveis ambiguidades decorrentes da leitura, da interpretação e do processamento do texto genômico (Kay, 2000). E a partir daí, os seres vivos passaram a ser definidos em termos de somatório de informações organizadas e contidas, em última instância, no genoma.

O entendimento da ação de elementos não genéticos na atividade molecular, entretanto, modificou a maneira como o corpo genético estava organizado, tornando-o mais fluido e menos definido num cenário muito mais interacional. As pesquisas atuais na área da epigenética, que trata da 
regulação e da expressão de certos genes sem modificação da estrutura básica do DNA, e o crescente interesse na complexa organização das células e seus processos deslocaram a ênfase dada antes apenas aos genes como responsáveis pela hereditariedade e como contendo a chave da vida.

Por conseguinte, para alguns autores, diante da ênfase nas relações e interações que caracterizam um pensamento 'pós-genômico', cujo foco foi ampliado dos genes e dos polimorfismos de nucleotídeo único (SNPs) ${ }^{10}$ para os processos de transcrição e sínteses de proteínas, a conhecida metáfora do 'livro da vida' ou 'código dos códigos' perdeu força e, com ela, o sentido da noção determinista e espetacular que envolvia os genes. Nesse aspecto, a linguagem informacional tornou-se insuficiente para expressar o tipo de intervenções feitas no nível molecular na 'vida em si', solicitando um novo e mais preciso repertório de palavras capaz de suscitar novas imagens e elementos imaginativos (Van Dijck, 1998; Keller, 2000, 2003).

Autores como Eugene Thacker (2006) desenvolvem um raciocínio que atualiza a estreita ligação entre biologia e informação, levando-a para além do discurso da metáfora informacional. Segundo ele, a biopolítica surgiu no compasso de formas de quantificação relativas ao domínio biológico e seus processos, como taxas de nascimento, morte e controle de doenças, por exemplo, alicerçadas na expansão da demografia, da estatística e da economia política. De forma similar, a biopolítica contemporânea mantém e amplifica esse vínculo com a informação, por meio dos computadores e da informática, tendo a genética como área de aplicação por excelência.

Contudo, ainda segundo Thacker (2006), a informação biológica, que é o ponto de convergência entre biopolítica, genética e informática e por meio do qual um modo de 'governamentalidade'11 é exercido, não pode ser entendida apenas como descorporificada ou imaterial, mas sendo em si material e também decisiva em materializar aquilo que é a 'vida em si'. Para ele, esse é um ponto fundamental que reconfigura o que se entende por informação, constituindo um aparente paradoxo que permeia os conflitos a respeito de se considerar a biologia como informação no âmbito da genética molecular e da biotecnologia. O autor diferencia o conceito de 
informação originalmente retirado do contexto da cibernética e da teoria da informação, no qual o foco é quantitativo, referindo-se mais à forma do que ao conteúdo ou significado, daquele que resultou da sua apropriação pela biologia molecular e cujo foco é exatamente o oposto, calcado no conteúdo da informação genética.

Thacker (2006) discorre sobre as trocas biológicas com base na proposição de Malcolm Waters (2001) sobre os tipos de trocas possíveis no âmbito do fenômeno da globalização. Para Waters, as trocas materiais tendem a demarcar espaços em razão da comercialização de bens, as trocas políticas levam a circunscrever fronteiras territoriais para fins de relações internacionais que reafirmam a soberania territorial, e as trocas culturais permitem a disseminação de imagens e símbolos pelos meios de comunicação de massa, desvencilhando-se das restrições espaciais. Thacker complementa essa proposição, acrescentando que as trocas biológicas são responsáveis por 'rematerializar' aquilo que, sendo originalmente material biológico (por exemplo, o DNA que pode ser transferido de um organismo a outro), foi codificado digitalmente (uma sequência num banco de dados) e posteriormente recodificado de diferentes formas (sintetizado ou rematerializado na forma de terapias gênicas, drogas ou, ainda, organismos geneticamente modificados).

Na indústria biotecnológica, além do trabalho humano ${ }^{12}$ que é realizado em diversos níveis, o trabalho biomaterial é levado a cabo por meio de novos meios tecnológicos, mas como atividade vital não humana (não consciente), realizada por células, enzimas, DNA. Como exemplos desse tipo de produção, pode-se citar as linhagens de células mantidas em laboratório com fins de pesquisa, as chamadas 'células imortalizadas'; os biorreatores mamários, criados para produzir um composto específico em seu leite mediante a introdução de um gene humano, composto este que é extraído, processado e purificado para ser usado na produção de medicamentos; e os modelos animais, usados para o estudo de diversas doenças, dentre os quais o mais conhecido é o OncoMouse, patenteado pela DuPont Chemicals, um tipo de camundongo geneticamente modificado com oncogenes para desenvolver câncer de mama. ${ }^{13}$ Aquilo que é tido como 
'natural' (biológico) é também tecnológico, sendo transformado em propriedade por meio de legislação de patentes. Em outras palavras, trata-se do que Hans-Jörg Rheinberger (2000) definiu como sendo não mais uma representação extracelular de processos vitais intracelulares, mas uma representação intracelular daquilo que constitui um projeto extracelular.

Cada vez mais busca-se a base genética das doenças, a ponto de se pensar em medicina como medicina genômica, ${ }^{14}$ o que significaria uma mudança da lógica de restauração de normatividade, perdida com a situação de doença, para uma de manipulação no nível molecular da 'vida em si'. Conforme aponta Rheinberger (2000), a relevância da perspectiva molecular em medicina foi erroneamente assentada não apenas na cura para as doenças, mas na noção de genes saudáveis para a população, afetando sobremaneira as expectativas de pacientes quanto aos cuidados com a saúde e a percepção dos médicos no que refere às doenças.

A ideia de suscetibilidade genômica substituiu a de determinismo genético e tem sido aplicada em diferentes esferas como em medicina reprodutiva, na área de marcadores genéticos que ajudem a prever a reação de pessoas a determinadas drogas, e no rastreamento genético em indivíduos assintomáticos, com possibilidade de identificação precoce, por meio de testes preditivos e diagnósticos, daqueles suscetíveis antes mesmo de desenvolverem ou apresentarem qualquer manifestação de doença.

Porém, à exceção de doenças que seguem o padrão mendeliano de apenas um gene envolvido, nas demais, apesar de possivelmente afetadas pela ação de certos genes, estes não têm poder de determinação quanto ao momento e às condições de aparecimento da doença ou ao seu curso. Um certo caráter 'divinatório' é, então, reintroduzido em associação a determinados processos, nos quais a informação expressa por meio de probabilidades carece de sentido clínico ou pessoal, oferecendo-se apenas como um apelo futuro (Lock, 2005). Assim, a análise gênica, ainda quando revela com alguma certeza determinadas doenças, nada pode dizer sobre as histórias corporificadas, apenas sobre características que fazem parte do repertório do humano, com suas suscetibilidades e adaptabilidades. 
O estabelecimento de suscetibilidades fornece explicações sobre o passado, ressignifica o presente e (re)orienta o futuro, delineando o que Rose (2007) denomina 'indivíduo sob risco genético' e deslocando o foco dos dois polos extremos do eixo saúde-doença. Daí resulta que numerosas intervenções, calcadas em concepções sobre o que é considerado como o estado ótimo dos seres humanos, são vislumbradas nesse presente ressignificado, com vistas a se obterem desenlaces melhores no futuro.

O indivíduo somático que emerge desse processo implica uma nova forma de cidadania biológica que solicita que ele reformule expectativas, obrigações, direitos, compromissos e responsabilidades, e remodele suas relações com o mundo e consigo mesmo, nas quais as perguntas 'quem sou eu?', 'de onde venho?' e 'qual o meu futuro?' ganham novos e possíveis contornos antes impensáveis que ampliam horizontes. As novas tecnologias genômicas produzem a diferenciação do indivíduo como parte de um corpo social, mas também o reconhecimento de si mesmo não por meio de sua imagem vista no espelho, como na teoria de Jacques Lacan (2007), mas da visualização que tais tecnologias permitem (Bratton, 2002).

Indivíduos geneticamente suscetíveis, apesar de não apresentarem a doença manifesta no corpo e talvez nunca a desenvolverem, trazem-na de algum modo inscrita potencialmente. Logo, são instados a pensar em termos de risco genético, a se familiarizarem com informações médicas e dados probabilísticos, a conciliar o corpo percebido em sua materialidade de carne, sangue e células com os construtos estatísticos resultados das pesquisas científicas. Devem decidir e se comportar de forma a tomar para si parte da responsabilidade por administrar seu patrimônio somático, otimizando-o. A busca por identificar suscetibilidades por meio de variações no nível de SNPs leva a um número maior de pessoas que potencialmente se encaixam na categoria de indivíduos suscetíveis, o que Rose (2007) categoriza como uma forma emergente de vida.

Atrelado ao entendimento ampliado de existência corpórea, novos profissionais surgem no panorama atual, multiplicando expertises somáticas e pastorais, cuja atuação está indiscutivelmente entrelaçada aos seus pacientes identificados como sujeitos ativos, seja na busca por compreensão 
de determinadas condições para fins clínicos ou de pesquisa, seja no processo de aconselhamento, especialmente genético, diante dos novos desafios decorrentes da identificação de uma doença existente ou potencial nas suas histórias individuais (Rose, 2007).

Os numerosos debates sobre os riscos relativos à discriminação genética em aspectos como emprego, seguro-saúde e seguro de vida provocaram, além do surgimento de leis específicas com vistas a regular um novo campo, a difusão de novas concepções sobre a condição de pessoa, o redelineamento de responsabilidades e consequentes dilemas éticos, amplamente apoiados em bases genéticas. A responsabilidade genética por administrar suscetibilidades e riscos individuais, o que incluiria a comunicação a parentes sobre doenças potenciais envolvendo suas vidas, pode colidir com o aspecto da confidencialidade da informação e do direito que essas pessoas têm de optar por não saber, ainda que isso se configure como 'irresponsabilidade' (Lemke, 2007).

Cada novo passo que é dado adiante nesse processo reativa medos antigos, que encontram canais de expressão pela referência a produções culturais emblemáticas, como o filme americano Gattaca: a experiência genética, de 1997, com foco na vigilância genética e em valores nitidamente iluministas. Ainda hoje evocado, ${ }^{15}$ Gattaca tornou-se uma metáfora para designar possíveis situações futuras que envolvem aspectos de engenharia genética para modificação de seres humanos e passou a ser usado como sinônimo de um mundo asséptico, no qual a tecnologia levou à discriminação de pessoas não modificadas ou aperfeiçoadas geneticamente. Determinadas imagens e elementos imaginativos, presentes em produções desse tipo, acompanham os desenvolvimentos científicos relacionados à genética e se revelam atuais e pertinentes à discussão sobre SD, permeando as narrativas analisadas, em especial a discussão sobre planejamento reprodutivo como forma de prevenir condições consideradas 'indesejáveis' e a discriminação em relação a essas 'imperfeições'.

A evocação desse filme, bem como de outras produções, torna-se significativa porque o mundo ficcional de Gattaca apresenta-se como uma experiência do fora, no sentido dado por Maurice Blanchot (1990) em sua 
discussão sobre realidade e espaço literário, colocando o espectador em contato com um mundo estranho, irreconhecível, diferente do cotidiano do qual ele e o autor fazem parte. Assim, apesar de o filme ser um relato em primeira pessoa, o narrador desaparece como 'eu', posto que se torna objeto de identificação: qualquer um do mundo não ficcional pode ser Vincent em sua 'imperfeição' genética. No mundo imaginário da ficção, tudo se desdobra em imagem: linguagem, tempo e realidade; o mundo apresentado é o desdobramento do mundo real e contemporâneo a ele, permitindo que o olhar sobre a realidade adquira uma nova forma, em uma perspectiva mais abrangente (Levy, 2003).

Para David Kirby (2009), enquanto certos tipos de representações cinematográficas de tecnologias futuras podem levar o público a temer determinados avanços científicos como potencialmente perigosos, outros compõem 'protótipos narrativos' que têm como função reduzir essa ansiedade, evidenciando a necessidade, a benevolência e a viabilidade de determinada tecnologia, ao apresentá-la como parte da realidade no mundo ficcional.

Com a disponibilidade de testes pré-natais que permitem o diagnóstico de um número crescente de condições, veicula-se a ideia de que ter um filho com algum tipo de deficiência é uma questão de opção ou, antes, uma falha num sistema de controle (Lemke, 2007). Ainda que esse possa ser um elemento decisivo em países nos quais a interrupção da gestação é regulamentada, esse não parece ser o único aspecto envolvido. Diante da inexorabilidade de um diagnóstico, significados outros que não os orgânicos são ensaiados e pronunciados, tornando-se verdades alternativas que apaziguam as ansiedades diante do desconhecido e fornecem respostas, ainda que provisórias, à dramática pergunta: 'por que comigo?' .

A representação artística antecipa a expressão daquilo que o ser humano não entende racional ou logicamente. Apesar de os primeiros trabalhos sobre SD surgirem no século XIX, essa parece ser uma condição muito antiga na humanidade, como indicam os registros claros na forma de esculturas, gravações e desenhos de indivíduos que a apresentavam, entre outros tipos de deficiência, na civilização olmeca que viveu entre os 
séculos 1500 a.C. e 300 d.C., ou ainda em pinturas renascentistas pelo pincel de diferentes artistas, como Andrea Mantegna, Fra Felippo Lippi e Jacob Jordaens (Stratford, 1996).

Um longo percurso separa os discursos sobre o que hoje se conhece como SD ou trissomia do cromossomo 21 e as numerosas tentativas anteriores de descrição e diagnóstico, cujas primeiras referências remontam a Jean Esquirol, publicadas em dicionário médico em 1838, passando pela 'idiotia do tipo mongol' referida em livro por Chambers em 1844 (Stratford, 1996), a 'idiotia furfurácea', descrita por Edouard Seguin em 1846, e a 'idiotia mongoloide' de John Langdon Haydon Down (1866), cujo trabalho teve o mérito de descrever as características físicas típicas que a identificam e de considerá-la como condição separada e distinta de outras, como o cretinismo, por exemplo, que tinha em comum o retardo mental, mas que resultava de uma desordem congênita da tireoide (Pueschel, 2005).

O trabalho de Down apresentava-se fortemente influenciado pelas concepções evolucionistas de Darwin, o que o levou a relacionar algumas características da síndrome a raças consideradas inferiores, desenvolvendo uma classificação étnica dos 'idiotas' (Schwartzman, 1999).

Após a descoberta do número correto de cromossomos das células somáticas humanas por Tijo e Levan em 1956, o pediatra e geneticista francês Jérôme Lejeune, que dedicou grande parte de suas pesquisas à SD, publicou em 1959, junto com Marthe Gautier e Raymond Turpin, o trabalho que descreve a etiologia genética da SD como uma anomalia cromossômica em razão da presença de uma cópia extra do cromossomo 21 (Lejeune, Gautier \& Turpin, 1959), constituindo uma aplicação à clínica da então nascente citogenética.

A partir do trabalho de Down, o termo 'mongolismo' passou a ser amplamente utilizado, até que em 1961 começaram discussões acerca da nomenclatura adequada que melhor traduzisse a condição (Lennox, 1961; Spalding, 1961; Benda, 1962) e manifestações contrárias ao uso do termo então corrente, entre elas uma carta publicada no periódico The Lancet (Allen et al., 1961), com 19 signatários, entre eles Langdon Down (neto), Jérôme Lejeune, Paul Emmanuel Polani e Lionel S. Penrose, pedindo a substituição 
do nome em razão da inadequação da associação de elementos raciais à síndrome, em termos não apenas médicos mas também sociais, devido ao preconceito daí decorrente com relação à população asiática, e em especial aos cientistas chineses e japoneses, cada vez mais presentes nas pesquisas sobre o assunto (Caratzali, 1961; Dunn, 1961; Hollman, 1961). Entretanto, foi apenas no segundo volume de 1964 que o periódico indexou a condição de acordo com a designação epônima. No Medical Subject Headings (Medline), o termo mongolism persistiu como descritor até 1975, quando foi substituído por Down's syndrome (Howard-Jones, 1979), enquanto no American Journal of Human Genetics a mudança ocorreu em 1971 (Miller, 2003). A partir de 1965, a pedido da delegação da Mongólia, o termo deixou de ser usado nas publicações da Organização Mundial da Saúde (Dunn, 1991).

O declínio do uso do termo 'mongolismo' e a sua substituição paulatina pela expressão síndrome de Down ou trissomia do $21^{16}$ significou a troca de um termo científico por outro, marcando uma mudança de abordagem da própria ciência e sua influência sobre a sociedade em geral, com o intercâmbio entre os círculos esotérico e exotérico (Fleck, 1981), por meio do qual a terminologia do primeiro é assumida pelo segundo.

Hoje, a SD é um ícone por se tratar de uma das condições genéticas mais frequentes, com incidência de 1:700 (Fonseca et al., 2005), sendo usada como exemplo por médicos e outros profissionais de saúde para explicar riscos e tecnologias de rastreamento e diagnóstico pré-natais. O nascimento de um bebê com SD provoca um impacto, mesmo quando diagnosticado intraútero. O momento do parto é investido de uma grande carga afetiva, marcando de forma indelével pais e profissionais, principalmente no tocante à comunicação do diagnóstico (Rapp, 2000).

Para os pais dessas crianças, o contato com o diagnóstico de SD demanda um tempo de assimilação, apesar de internamente já saberem que existe algo de diferente com seus filhos, e a observação orientada pelo médico desses sinais aparentes constitui prova irrefutável que lhes dá acesso ao olhar especializado, possibilitando ver o que os médicos veem, e a consequente aceitação do diagnóstico. 
Em geral, a SD apresenta-se de forma inequívoca, o que significa que os indícios, as características semióticas necessárias ao estabelecimento do diagnóstico clínico, estão presentes em até $60-80 \%$ dos casos. Muitos traços foram descritos como característicos da síndrome, mas existem aqueles mais comuns, denominados 'sinais cardeais' ${ }^{17}$ por servirem de orientação e fundamentação para o diagnóstico. Na forma mais comum da SD, 95\% dos casos, o que ocorre é a presença de um autossomo 21 extra na chamada trissomia simples, configurando os seguintes cariótipos: $47, \mathrm{XX}+21$ ou $47, X Y+21$. Cerca de $4 \%$ dos casos apresentam uma translocação, o que significa que o cromossomo 21 adicional está fusionado com outro autossomo, em geral o 14 ou o 22. Numa percentagem menor ainda, encontra-se o mosaicismo, que apresenta células trissômicas em meio a células normais em termos citogenéticos (Selikowitz, 1997).

A presença da SD num bebê marca a necessidade de avaliação por vários profissionais médicos e não médicos. A sensação de que ele(a) é de alguma forma 'diferente' ou 'inadequado(a)' está presente em estudos feitos com pais de crianças com essa condição (Rapp, 2000). À alta incidência de casos de SD soma-se o aumento da sobrevida proporcionada pelo avanço das tecnologias biomédicas, as quais envolvem desde um acompanhamento clínico adequado até atividades e estímulos necessários ao desenvolvimento motor e cognitivo, o que pode ser traduzido como uma otimização de sua corporalidade e vitalidade, levando a um maior bem-estar.

A ênfase dos protocolos clínicos é no sentido de detectar e prevenir as comorbidades que afetam a vida dos indivíduos com SD, por meio de um rastreamento que varia de acordo com a idade. As condições mais frequentes a serem identificadas são: defeitos cardíacos congênitos, atresia intestinal, doença de Hirschsprung, doença celíaca, leucemia, autismo e outros distúrbios psiquiátricos, convulsões, hipotireoidismo, diabetes, instabilidade atlantoaxial, subluxação atlantoccipital, obesidade, entre outras. Entretanto, a necessidade de um acompanhamento multidisciplinar tem aumentado em razão da complexidade que envolve o cuidado a essas pessoas (Crissman et al., 2006). 
O mapeamento do cromossomo $21 \mathrm{em} 2000$ identificou mais de quatrocentos genes. Entretanto, apesar de sua sequenciação, ainda pairam indefinições quanto ao papel desses genes, suas funções e suas complexas interações com genes de outros cromossomos e com o ambiente (Crissman et al., 2006).

A busca pela localização de regiões determinadas do cromossomo 21 e suas correlações com o fenótipo, com o intuito de prevenir ou minimizar efeitos, está calcada hoje na compreensão dos efeitos resultantes da carga gênica extra e dos seus produtos proteicos, em especial no tocante ao sistema nervoso central (Capone, 2001; Crissman et al., 2006). A presença significativa de indivíduos com SD como membros atuantes na comunidade tem demandado pesquisas que possibilitem uma maximização de seu potencial em termos funcionais. Estas se voltam para o entendimento do papel dos genes envolvidos nos processos bioquímico-celulares relacionados à capacidade cognitiva dessas pessoas, de forma a desenvolver intervenções farmacológicas que atuem nessa área. Para tanto, são utilizados modelos animais, particularmente camundongos, que permitam a comparação de regiões genômicas desses organismos para a identificação de proteínas ortólogas às humanas, isto é, proteínas que mais se assemelhem às codificadas pelos genes, nesse caso localizados no cromossomo 21 , e cuja semelhança resulta da conservação no processo evolucionário de genes ancestrais comuns a essas espécies, de forma a se observar a sua ação em correlação com o fenótipo em SD (Gardiner \& Costa, 2006).

Diante da utilização cada vez mais elaborada de modelos animais, por meio dos quais o homem pode conhecer mais sobre o homem, a expressão de Rimbaud "the man of the future will be filled with animals", 18 conforme aponta Rabinow (1992), é ressignificada materialmente, na perspectiva da era genômica.

Ao se olhar com distanciamento crítico, percebe-se que tais mudanças delineiam a evolução da percepção da sociedade a respeito de uma condição como a SD e aqueles que com ela vivem, compondo referências somáticas históricas que só são acessíveis por meio do questionamento das certezas estabelecidas sobre o tema. 
A ideia sobre pessoas que têm SD surge e é disseminada a partir do momento em que elas se tornam foco de preocupação social. Sob o termo 'ideia' agrupam-se conceitos, crenças, atitudes, concepções, teorias, os quais são criados em cenários sociais, ou matrizes, compostos por uma complexa rede de instituições, atores, meios de comunicação e as interações entre eles (Hacking, 2000). Em suas críticas ao construcionismo social e sua miríade de objetos de estudo, o filósofo Ian Hacking (2000) argumenta que não são os objetos em si que são construídos, mas as ideias sobre eles, entre os quais seres humanos, gerando uma espécie de classificação, demarcando um 'tipo' específico de pessoa que é reconstruída dentro do cenário social no qual essa ideia é gerada. Enquanto certos tipos são interativos por afetarem os objetos classificados - pessoas, por exemplo -, outros são indiferentes, isto é, os objetos permanecem inalterados diante da classificação, como nos fenômenos físicos, biológicos ou químicos. Por conseguinte, no tocante às pessoas com SD, não são os indivíduos em si que são construídos socialmente (estes existem no mundo!), mas a ideia sobre eles (especiais, diferentes, que precisam ser incluídos), e por serem desta forma classificados, interagem com essa ideia ou 'tipo' e se modificam em sua existência particular. Essa modificação decorre não necessariamente de uma autoconsciência individual de tal classificação, mas de uma percepção compartilhada e desenvolvida num grupo e que permeia as práticas e instituições relacionadas a esses indivíduos, justamente por terem sido assim classificados. E é essa ideia que este livro buscou acessar por meio da análise das imagens presentes nas narrativas escritas e iconográficas sobre SD.

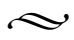

Esta Exposição localizou a paisagem biológica em que se constitui a SD e percorreu os fios que a conectam ao panorama mais amplo da política vital contemporânea, cujo principal elemento, a molecularização do estilo de pensamento biomédico, é acompanhado por outras mudanças também marcantes, concernentes à redefinição do humano em termos de uma existência somática. Tais mudanças referem-se à otimização de suas 
potencialidades para além do binômio saúde-doença e ao surgimento de novos profissionais para atuar nessa existência somática e novas formas de governá-la; e também à inclusão dos processos vitais no âmbito da circulação de mercadorias e da geração de biovalor, conformando economias da vitalidade, nas quais os limites entre o que é ou não considerado como humano - e, portanto, passível de ser comercializável - tornam-se pouco nítidos (Rose, 2007).

Nos termos da metáfora da fuga, aqui livremente usada para organizar a apresentação do livro, fez-se a exposição do tema principal ou sujeito, a SD, demarcando-se os pontos de entrada onde o tema começa numa outra voz. Nos episódios subsequentes, as diversas vozes cantarão o sujeito e darão respostas em tonalidades distintas, entrelaçando-se até se juntarem, todas, em múltiplas declarações sobre o tema.

NotAs

1 “O tempo presente e o tempo passado / Estão ambos talvez presentes no tempo futuro / E o tempo futuro contido no tempo passado. / Se o tempo é eternamente presente / Todo o tempo é irredimível. / O que podia ter sido é uma abstração / Permanecendo uma possibilidade perpétua / Apenas num mundo de especulação. / O que podia ter sido e o que foi / apontam para um fim, que é sempre presente. / Passos ecoam na memória / Ao longo do corredor que não tomamos / Em direção à porta que nunca abrimos..." (Tradução livre).

2 No original: "One blanket. Many states. Many countries. Hundreds of families. One common thread!". Disponível em: <http://www.thet21travelingafghanproject.com>. Acesso em: 1 jul. 2009.

3 Ver o endereço eletrônico < http://www.thet 21 travelingafghanproject.com/ > . Acesso em: 1 jul. 2009.

4 Um dos exemplos mais conhecidos é o relacionado à doença genética PXE (Pseudoxanthoma elasticum). A esse respeito, ver Terry e Boyd (2001) e Terry e colaboradores (2007).

5 Neste livro, a sigla em inglês será usada por ser a que é amplamente veiculada na mídia, na linguagem cotidiana e nas narrativas analisadas. 
6 Foucault (2003c) descreve que o tema do poder pastoral, apesar de estar presente nas sociedades orientais antigas, como Egito, Assíria e Judeia, em associação com a figura de deidade, rei ou líder, e nos gregos nas figuras do médico, do educador ou do responsável pela educação física, entre outros, é mais intensamente desenvolvido pela sociedade hebraica, tornando-se de fundamental importância no pensamento cristão e nas instituições constituídas posteriormente. Segundo o autor, o que o caracteriza é uma forma de poder exercida pelo pastor sobre um rebanho, e não sobre um território fixo, com a incumbência de prover o seu sustento e a sua salvação na realização de um propósito. Ao mesmo tempo, é um poder que individualiza, ao valorizar a devoção a cada indivíduo do rebanho e a este como um todo. As relações que se estabelecem entre esses indivíduos e o pastor são de obediência e submissão. Foucault percorre as origens dessa modalidade pastoral de poder para discutir os caminhos e a importância que ela assume na sociedade ocidental como tecnologia de poder, baseada num tipo específico de racionalidade, com o propósito de intervir na vida dos indivíduos, que habitam um mesmo território, com vistas ao fortalecimento do Estado.

7 Células-tronco são células indiferenciadas capazes de ampla proliferação (Nussbaum, McInnes \& Willard, 2002).

8 Genoma é a soma das informações genéticas de uma espécie, codificadas no núcleo de cada célula do organismo (Nussbaum, McInnes \& Willard, 2002). O Projeto Genoma Humano é resultado de um consórcio internacional para sequenciar e mapear o genoma humano, assim como de outros organismos de interesse para a biologia (Keller, 2000).

9 Código genético é a chave de tradução da relação entre aminoácidos específicos de uma proteína e uma sequência de nucleotídeos (Nussbaum, McInnes \& Willard, 2002).

10 Variação que ocorre numa única base (nucleotídeo) na sequência do DNA (Nussbaum, McInnes \& Willard, 2002).

11 Foucault (2003d) se refere ao termo 'governamentalidade' como um modo de pensar e de agir sobre a conduta de outros indivíduos; o conjunto de instituições, procedimentos, análises, cálculos e estratégias que permitem o exercício de um tipo de poder, instrumentalizado por meio do saber econômico, com utilização de dispositivos de segurança e cujo campo de intervenção é a população, considerada em seus aspectos de volume, densidade e território que ocupa. Miller e Rose (2008a) destacam três 'famílias' de 'governamentalidade': o liberalismo clássico, o Estado de Bem-Estar Social e o liberalismo avançado.

12 Nessa discussão, Thacker (2006) faz uma articulação entre os conceitos de 'biopolítica' de Foucault e o de 'ser-espécie' de Marx, dando ênfase especial à definição de trabalho biológico realizado pelo homem, como ser-espécie, que seria foco do controle biopolítico contemporâneo.

13 Para uma discussão mais aprofundada, ver Thacker (2006) e Haraway (1997). 
Em editorial de 1996 em The Lancet, "Have you had a gene test?", a não separação entre testes médicos e testes genéticos já despontava como sendo apenas uma questão de tempo para que se consolidasse. A expressão 'medicina genética' aparece no jornal $O$ Globo em 28 de março de 2004, em referência a testes diagnósticos para doenças genéticas.

15 Em 2009, o filme Gattaca foi citado em duas reportagens nos jornais britânicos The Times e The Sunday Times, versão on-line. Respectivamente, a primeira delas, um artigo escrito pelo autor do livro 50 Genetics Ideas You Really Need to Know, Mark Henderson, sobre testes para mapeamento de DNA oferecidos diretamente ao consumidor e o treinamento necessário requerido para que médicos generalistas possam interpretálos (The Times, 2009); a segunda, sobre o uso de diagnóstico genético pré-implantação para fins não médicos, como escolha do sexo do bebê ou de outros traços, por exemplo (The Sunday Times, 2009). O filme também é utilizado como ferramenta de ensino para abordar implicações éticas relacionadas a esse tipo de tecnologia, conforme se pode ver no site Teach with Movies Disponível em: <http://teachwithmovies.org/guides/ gattaca.html>. Acesso em: 13 mar. 2008.

16 Ian Hacking (2006) cita a identificação da associação entre o cromossomo 21 extra e a síndrome como sendo um dos exemplos da preponderância do aspecto genético na medicina no tocante à nomeação de determinadas condições, especialmente na semântica francesa, que utiliza preferencialmente a denominação trissomia do 21. Cabe ressaltar que a tendência dos trabalhos científicos de língua inglesa a usar Down('s) syndrome e a dos escritos em francês a utilizar trisomie vingt-et-un possivelmente se relaciona ao fato de ter sido um inglês, Langdon Down, a descrever a síndrome com mais acuidade e ter sido um francês, Jérôme Lejeune, a identificar a sua etiologia genética (Cardoso, 2000). Observa-se que, no Brasil, as narrativas analisadas tendem a usar síndrome de Down; os blogs em língua inglesa, em geral, apesar de também usarem Down('s) syndrome, apresentam as duas denominações, como forma de ampliar para o público o conhecimento sobre a condição.

17 São eles: olhos com inclinação para cima e para fora; presença de uma dobra na pele na parte interna do olho, chamada epicanto; fissuras palpebrais oblíquas; pequenas manchas visíveis na borda da íris, as manchas de Brushfield; face com perfil achatado com tendência à ponte nasal baixa; cabeça usualmente menor do que a média, cuja parte posterior apresenta-se achatada, com fontanelas maiores; orelhas pequenas e baixas; lábios finos e boca pequena, que tende a permanecer entreaberta; devido ao menor espaço interno, a língua é geralmente protusa; excesso de pele na nuca; membros curtos, desproporcionais em relação ao tronco, mãos planas e alargadas, presença de clinodactilia; pés também aplanados e largos, com maior distância entre o artelho e os outros dedos; hipotonia e tendência à hiperflexibilidade; reflexos débeis; padrões 
específicos de dermatóglifos (entre eles prega palmar única e arco tibial na impressão plantar) (Cunningham, 1996).

18 Tradução livre: "O homem do futuro será preenchido com animais". 
O código genético disso a que, sem pensar muito, nos temos contentado em chamar natureza humana, não se esgota na hélice orgânica do ácido desoxirribonucleico, ou ADN, tem muito mais que se lhe diga e muito mais para nos contar, mas essa, por dizê-lo de maneira figurada, é a espiral complementar que ainda não conseguimos fazer sair do jardim-de-infância, apesar da multidão de psicólogos e analistas das mais diversas escolas e calibres que têm partido as unhas a tentar abrir-lhes os ferrolhos.

José Saramago

(Ensaio sobre a Lucidez, 2004: 28-29) 


\section{Primeiro Episódio:}

IMAGENS PLURAIS

Aspectos como qualidade de vida, estigma, sofrimento e expectativas influenciam como determinada condição é encarada e dependem da subjetividade individual e das pressões sociais. Entram em cena questões sobre o significado do desvio da norma, que se relacionam não apenas à exclusão, mas também à responsabilidade da sociedade sobre os indivíduos desviantes.

No caso de uma condição genética como a síndrome de Down (SD), são cada vez mais frequentes as discussões lançadas pelos meios de comunicação, em reportagens, filmes, campanhas, novelas, documentários, nas quais a tônica é o modelo de inclusão, alicerçada muitas vezes em documentos oficiais, tais como a Política Nacional de Saúde da Pessoa Portadora de Deficiência (Brasil, 2008) e o documento sobre o Direito à Educação Inclusiva (Brasil, 2004).

Nessas discussões, as noções trazidas reforçam a ideia da necessidade de um letramento ${ }^{1}$ por parte da população, mediante o correto entendimento das informações veiculadas, com tendência a transformar a multiplicidade de vozes e significados em monólogo: o discurso biomédico, literal.

Numa sociedade que enfatiza a racionalidade como seu fundamento básico, a SD é um ícone por ser uma das condições genéticas mais frequentes e que tem no retardo mental a principal marca do estranhamento que o contato com ela provoca. 
Porém, o foco nas discussões pouco se refere aos outros elementos que permeiam as imagens sobre SD socialmente difundidas e que estão no cerne da aparente simplicidade com que o assunto é tratado nos dias atuais.

Percebe-se que o público em geral já ouviu falar em SD, mas tem-se a impressão de que escassamente se fala sobre as pessoas que a têm. Parece haver certa invisibilidade que impede que tais pessoas sejam realmente vistas e permaneçam camufladas pelo anseio da sociedade em acomodar aquilo que ela não suporta, mas que é sua parte intrínseca.

Não apenas os indivíduos, mas a sociedade cria concepções, valores e imagens sobre genes, herança genética, testes, aconselhamento genético e condições específicas, como a SD, que vão ditar formas de entendimento e de ação e reação às informações sobre os riscos envolvidos, ou à presença de alguma dessas condições em suas histórias individuais.

Esse repertório se manifesta na produção cultural sobre SD e proporciona um recorte de como uma condição geneticamente determinada é entendida e vivida por todos. Analisá-lo permite explicitar como a sociedade interage com seus conceitos de normalidade, anormalidade e estigma, demarcando os limites entre o igual e o diferente, entre o padrão e o desvio.

Neste episódio, discutem-se três narrativas principais, o slogan "Ser diferente é normal", o quadro de Andrea Mantegna que representa a Virgem com o Menino Jesus (Madonna col Bambino) e a imagem do vídeo Do Luto à Luta representando um casal com SD, e duas narrativas a elas associadas, a fotografia veiculada com o slogan em 2003 e 2004 e uma pergunta feita ao casal no programa Marília Gabriela Entrevista.

A análise dessas narrativas, logo no início da pesquisa, revelou um dos principais elementos para a discussão: a normalização da diferença, que está presente de forma mais ou menos explícita nas demais narrativas e que se manifesta no slogan. Pelo seu caráter instrumental, demonstra-se a forma como se construiu esse raciocínio por meio da aplicação do quadrado semiótico ao slogan. 


\section{lMagens e PaLAVRas}

É próprio das sociedades humanas narrar seu passado, atualizá-lo por meio da memória, traduzindo visões de mundo, significados atribuídos pelos seres humanos que as compõem ao que os cerca, incluindo seus corpos com suas capacidades, limitações e formas de adoecimento.

Da mesma forma, a sensibilidade tem uma história; adquire significação através dos tempos e materializa-se nas pessoas de acordo com ideias e valores de determinada cultura, numa época específica. Mas, em contraste, nem sempre ela se mostra capaz de ser sensível a si mesma isto é, o modo como as sensações auditivas, táteis, gustativas, olfativas e visuais são significadas e como o homem é capaz de acessar o mundo por meio da sua mediação nem sempre se torna objeto de reflexão.

Pensamento e sensação não coincidem necessariamente. O que é pensado sobre os corpos em termos do contato consigo mesmo ou do contato com outros, diferentes em etnia, sexo, em aparência considerada normal ou não, ou em estado de adoecimento, refere-se a essa sensibilidade, e a não coincidência manifesta-se nas incongruências entre pensar e agir, entre sentir e significar e na expressão de julgamentos e preconceitos.

A apreensão de uma imagem ou de uma palavra solicita maneiras de conscientização diferentes. Contudo, tanto as imagens sugerem palavras quanto as palavras permitem a evocação de imagens, ainda que não seja possível discernir os significados envolvidos ou expressá-los discursiva ou conceitualmente. James Hillman (1992) define imagem como algo irredutível, como repertório primário e não como resultado de sensações e percepções, ou como construto mental representativo em termos simbólicos de ideias ou sentimentos. Para o autor, as imagens são os fundamentos que possibilitam os movimentos da psicodinâmica. O pensar por imagens é uma faculdade humana fundamental, e o discurso por imagens pode emergir de qualquer tipo de linguagem, mesmo a que parece mais afastada da imagem visual, como a linguagem científica (Calvino, 1990).

A sociedade ocidental transformou-se numa civilização da imagem, com predileção por metáforas visuais de perspectiva e distância relacionadas ao estabelecimento do que é considerado como verdade. Cada vez mais, 
o processo de desenvolvimento de tecnologias voltadas para o aperfeiçoamento das imagens enfatiza as sensações visuais em detrimento dos demais sentidos.

Apesar de a imagem ser amplamente alardeada e de oferecer múltiplas interpretações, o contato com ela encontra-se, por vezes, impregnado de uma lógica dual que estabelece padrões de certo e errado, de normal e anormal.

A história dos saberes, do conhecimento científico, das instituições, traduz o processo de constituição da sociedade, com suas redes possíveis de relação. Ludwik Fleck (1981), ao discutir a gênese e o estabelecimento de um fato científico, aponta que ele se dá com base em um complexo processo de consolidação social, no qual estão envolvidos aspectos perceptuais que tendem a considerar a realidade independentemente daquele que percebe, tornando o fato em questão algo permanente, livre de interpretação subjetiva do cientista. Porém, o que existe é um estado de consenso que assume que o pensamento científico está isento de emoções que influenciam a dita objetividade da ciência.

Na SD, uma condição irreversível determinada pela presença de um cromossomo 21 extra, associada ao retardo mental, a pessoa traz características particulares aparentes no corpo, além de traços invisíveis ao olhar comum, inscritos nos cromossomos, que traduzem aspectos individuais hereditários e identitários.

A SD se manifesta em imagem em dois sentidos: no tocante às suas características físicas indiscutíveis e identificáveis numa pessoa; e no sentido virtual, por meio de um diagrama representando a zona crítica da síndrome, por exemplo, uma topografia literal mapeada, supostamente livre de linguagem figurada, adquirindo estatuto preditivo, preventivo e de controle sobre o que é inequivocamente aparente. 


\section{O UM e o Múltiplo}

A percepção que a sociedade tem de pessoas que apresentam alguma deficiência física ou mental está firmemente associada aos valores por ela apregoados e à maneira como sua sensibilidade está desenvolvida, determinando sua maior ou menor inserção social dependendo do grau daquilo que é considerado como desvio.

As conotações de normalidade e de desvio da norma surgiram no final do século XIX, atreladas às novas leis relativas à contagem e à classificação de pessoas e seus hábitos e expressas em termos de probabilidade (Hacking, 1990). Hoje, a sociedade ocidental é guiada pelo modelo de normalidade, que valoriza conceitos como beleza, perfeição e capacidade de produção, considerando como estranho e diferente o que não corresponde ao padrão. Mais do que dissonantes, os desvios são, para muitos, assustadores por gerar instabilidade nas referências organizadas que se têm do mundo, tornando-se um risco por apresentar algo desconhecido que tensiona as cordas da imperfeição de cada um. Dito de outra forma, o desconhecido só é reconhecido como tal porque se conecta àquilo que é familiar.

As definições de doença e desvio expressam sentidos diferentes daqueles estabelecidos pela cultura como normais. Ao mesmo tempo que são rejeitados, são fundamentais por trazerem à luz aquilo que é parte da sociedade e que ela tenta excluir.

O conceito de corpo também varia de acordo com os momentos históricos e os processos sociais. Normas vitais e normas sociais estão entrelaçadas, e a definição de um ser humano normal, física ou mentalmente, modifica-se de acordo com a percepção de limites e possibilidades do eu. O que se observa, atualmente, é uma crescente plasticidade dos corpos, pela possibilidade de modificá-los e aprimorá-los por meio de tecnologias diversas, e uma flexibilidade das identidades, fortemente calcadas em aspectos de um 'eu' somático (Rose, 2007).

O olhar sobre o corpo tornou-se cada vez mais molecular, assim como o entendimento acerca da suscetibilidade às doenças e dos riscos 
envolvidos. A noção de suscetibilidade interpõe um terceiro elemento entre o normal e o patológico, diferindo da lógica dual na qual o papel da medicina é eliminar a doença e restaurar uma normatividade, ainda que distinta da anterior. Assim, os limites entre saúde e doença perdem seus contornos, tornando-se imprecisos. A suscetibilidade não está apenas relacionada à percepção pessoal de uma modificação nas normas vitais pela doença, mas à possibilidade de ação médica diante da definição e do diagnóstico de uma situação de doença em potencial.

Em termos gerais, a nova ordem mundial, abarcando o que se convencionou chamar de 'globalização', refere-se a processos que vêm transformando o mundo não apenas no âmbito da economia, com velocidade sem precedentes, e que ultrapassam as fronteiras nacionais e a localização geográfica. É um projeto que comporta mais do que um único e simples significado, e não cabe aqui desenvolver uma discussão aprofundada sobre o assunto. A questão considerada relevante relaciona-se à forma como produtos, imagens, corpos, identidades e subjetividades são reconfigurados pelo global (Franklin, Lury \& Stacey, 2000) e como as trocas culturais resultantes promovem a circulação de signos através dos meios de comunicação de massa em termos globalizantes.

O global atua de forma a tornar o estranho próximo ou familiar. Por meio do consumo daquilo que é exótico, que é 'outro', a sociedade ocidental assimila a diferença, supostamente eliminando-a, quando, na verdade, o que ocorre é a sua reafirmação.

Muitas vezes, os movimentos sociais que pretendem incluir aqueles que se apresentam como estranhos, sejam pessoas com SD, sejam homossexuais ou de etnias minoritárias, dentre outros, comportam-se de forma a 'consumi-los', aparentemente valorizando em seu discurso as diferenças existentes, desde que, paradoxalmente, eles se tornem iguais ao padrão, o que significa, em última instância, reafirmar a estranheza segundo uma escala de valores.

O estranhamento que surge ao receber o diagnóstico de SD torna os pais incapazes, a princípio, de ler no filho os seus próprios traços, como se as marcas aparentes da SD sobrepujassem as da própria hereditariedade e 
criassem outra forma de parentesco que une homogeneamente aqueles que compartilham essa condição (Cardoso, 2003).

Percebe-se que o conceito de normalidade diz respeito a um padrão convencionado socialmente, estabelecendo aqueles que são iguais e que se configuram como 'mesmo' (Haraway, 1991). O 'mesmo' é o indominado, constitui-se como ser autônomo, com poder. O que foge ao igual, ao normal, apresenta-se como diferente, como desvio, como 'outro'. O 'outro' é múltiplo e, como tal, difuso, menos demarcado e, portanto, mais ameaçador. Para que a inclusão desse 'outro' seja possível, é necessário ajustar a diferença, eliminando suas marcas e tornando 'mesmo' aquele que era 'outro' (Keller, 1999).

As primeiras campanhas lançadas pelo Instituto MetaSocial (1996, 1998 e 2001) na forma de filmes de curta duração 'apresentavam' a pessoa com SD para o público, num processo de aproximação paulatina com algo que, até então, era desconhecido ou ignorado por estar fora da vida da maioria das pessoas. Os dois focos eram: a inimaginável capacidade de alguém com essa condição (em 1996, "Pianista", e em 2001, "Garçonete"); e o preconceito como uma 'síndrome' pior do que a SD (em 1998, "Carlinhos" e seu amigo, um menino de rua). Subliminarmente, buscavam desestabilizar uma forma de percepção naturalizada em relação a essas pessoas, instando o público a prever desenlaces para as situações apresentadas nos filmes que se revelavam como julgamentos preconcebidos.

Em 2003, o slogan "Ser diferente é normal" significou uma nova etapa na atuação do instituto, com ampla divulgação da imagem de pessoas com SD. O mesmo slogan foi veiculado com diferentes imagens em 2003-2004, 2005 e 2008, também no formato de filmes curtos.

A campanha "Adolescente", veiculada em 2003 e 2004, retratava uma adolescente de 15 anos com SD, com as características 'típicas' da fase. O filmete mostra a jovem num lugar que se assume que seja a sua casa (uma casa de classe média), dançando entre os espaços da sala, do corredor e seu quarto, o qual é decorado com os elementos presentes em qualquer quarto de alguém nessa idade: fotos, bichos de pelúcia, cenário multicor. A música usada como elemento da narrativa é A Little Less 
Conversation, ${ }^{2}$ interpretada por Elvis Presley, cuja letra é um convite explícito à ação, ao movimento. Porém, um aspecto passa quase despercebido: apesar de a fase adolescente envolver a formação de grupos com interesses comuns, vestuário e comportamentos semelhantes, entendidos como marca de pertencimento ao grupo e como forma de afirmação de uma identidade em construção, a jovem diverte-se sozinha, claramente satisfeita consigo mesma, mas sozinha.

Em 2005, a campanha "Diferenças" referia-se não apenas à SD, mas à dita diversidade humana, focando em pessoas com diversos aspectos ou estilos e fenótipos/genótipos: diferentes texturas de cabelos e formas de arranjá-los, piercings, tatuagens, corpos magros, outros nem tanto, corpos com musculatura trabalhada. Outro grupo de pessoas é composto por um cego, uma pessoa em cadeira de rodas (que também é negra), um albino, outro negro e uma pessoa com SD (a mesma da campanha de 2003). A música de fundo é instrumental, e uma voz em off evoca uma similaridade entre as pessoas, seus pensamentos e sonhos, e a necessidade de oportunidades iguais. A igualdade é localizada espacialmente "no fundo" (nas células? nos cromossomos? no espírito?), enquanto as "pequenas diferenças" são visíveis na superfície do corpo. O filmete apresenta pessoas que podem ser agrupadas de duas maneiras: aquelas com diferentes estilos, resultado de opções quanto à forma de dispor e de se relacionar com seus corpos; e aquelas nas quais a diferença 'visível' independe da vontade, seja pela configuração genética como na SD, no albinismo, na cor da pele, dos olhos, no tipo de cabelo, seja em casos como o da cegueira e do uso de cadeira de rodas, cuja origem não é citada na produção. A SD é a única situação que envolve retardo mental.

Em 2008, o slogan voltou-se novamente para pessoas com SD, com atuação da mesma adolescente na campanha "Menina azul". Ao som de uma música instrumental, ela é vista em diversas situações (na rua, no elevador, na sala de aula), mas sem interagir diretamente com ninguém, e a narração em off, feita por uma voz feminina que não é a sua, conta o processo de transformação por que passou desde quando tinha a cor 'azul' . 
Apesar de se sentir bem em sua cor azul, considerada por ela uma cor "legal, positiva", ${ }^{3}$ era olhada como estranha, diferente, o que a levou a tentar várias outras cores (vermelho, laranja, lilás, amarelo, magenta), porém sem sucesso, até chegar à cor "básica" (a dos humanos considerados 'brancos'), quando passou a não ser mais vista como "tão" diferente. A partir daí, a interação acontece, mesmo reconhecendo que alguns ainda a consideram diferente, o que, segundo ela, é só uma questão de tempo. Mais uma vez, a diferença é localizada na superfície: a cor - não a cor como elemento definidor de um ultrapassado conceito de 'raça', mas como evocação de algo que se assemelha a uma forma 'alienígena' (ou não humana) de existência. A expressão da diferença como multiplicidade é substituída no decorrer do filme pelo elemento de igualdade, a cor 'básica' comum a um tipo específico de ser humano, e o uso da voz de outra pessoa (que mascara a dificuldade de verbalização comum a muitas pessoas com SD), reafirmando a tendência a eliminar a marca da diferença pelo tornarse igual ao padrão.

Buscou-se compreender mais profundamente a relação entre os termos 'normal' e 'diferente' no slogan "Ser diferente é normal". Para tanto, utilizou-se o quadrado semiótico como ferramenta complementar, de forma a permitir o desdobramento desses termos em outras possibilidades semióticas e testar a hipótese que os coloca numa mesma totalidade de sentido. O quadrado semiótico é formado por termos geradores $\left(S^{1}\right.$ e $\left.S^{2}\right)$, que compõem a categoria escolhida para análise, e a negação destes $\left(-S^{1}\right.$ e $\left.-S^{2}\right)$. A disposição no quadrado gera um dinamismo que faz aflorar relações de contrariedade/oposição, contradição e complementaridade. Cabe destacar que essas relações se referem ao texto em questão, não podendo ser generalizadas para todos os textos. A categoria isotópica analisada 'condições alteradas' $-{ }^{4}$ comporta os semas 'normal/trissomia 21 '. Se 'normal' mantém uma relação de disjunção com 'diferente' e este corresponde à 'trissomia 21 ', pode-se considerar que 'normal' equivale a 'igual', traduzindo aquilo que é padrão, desejável, ou seja, pode-se considerar a diferença como parte integrante da maioria. 
Convencionalmente, é possível se 'deslocar' pelo quadrado semiótico nos sentidos horário e anti-horário, num percurso ampliado $\left(S^{1}-S^{2}\right.$ via $-S^{1}$; $S^{2}-S^{1}$ via $-S^{2}$ ) que permite visualizar as inúmeras possibilidades contidas entre dois termos e que, nesta narrativa, abarca desde o que se configura como padrão ao que se considera como desvio. Graficamente, essa operação é expressa da seguinte forma (Figura 1):

Figura 1 - Quadrado semiótico aplicado ao slogan "Ser diferente é normal"

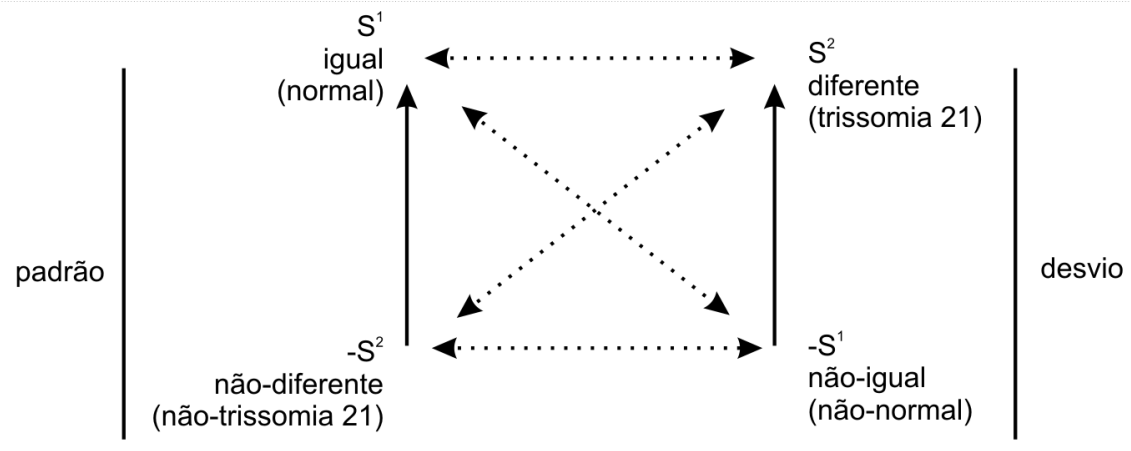

O processo revela, portanto, um significado implícito ao slogan "Ser diferente é normal": 'Ser diferente é igual', tornando patente a contradição entre o que se deseja veicular e o que é transmitido indiciariamente.

A fotografia associada ao slogan em 2003 e 2004 representa a adolescente vestida com cores vibrantes (blusa verde e calça vermelha, sapatos baixos brancos), cabelos castanhos lisos, longos e esvoaçantes, contra um fundo branco. Ela olha diretamente para a lente (para o público) e sorri; tem os braços esticados para a frente e faz com as mãos um gesto típico dessa faixa etária (com o polegar e o dedo mínimo estendidos e os outros dobrados), que transmite a ideia de pertencimento a um grupo (apesar de aparecer sozinha no filme) e tem significados relacionados à apreciação de algo como interessante ou como forma de cumprimento. ${ }^{5}$ Superpostas a essa representação, em tamanho reduzido, encontram-se desdobramentos da mesma adolescente, em posturas claramente associadas a movimento e 
feminilidade e que conotam um ar de satisfação consigo mesma e de sensualidade. Abaixo, lê-se o slogan; no canto superior esquerdo, o endereço institucional eletrônico.

Duas ideias prevalecem nessa imagem: movimento e multiplicidade. O movimento marca a autonomia, reforça a ideia de normalidade e, portanto, de ser o 'mesmo'. Em contrapartida, a multiplicidade explicita o ser 'outro' e aponta novamente para aquilo que é pouco demarcado e de certa forma desconhecido.

As palavras 'diferente', 'diferença', 'diversidade', associadas a pessoas que se apresentam como 'outros', ou não iguais, como no caso da SD, têm sido extensamente disseminadas (Gray, 2009), sendo consideradas como categorias supostamente definidas, estáveis, transparentes e compartilhadas por todos. Entretanto, cabe questionar se tais palavras são capazes de descrever o que se propõem, o que Luis David Castiel chama de "sensibilidade epistemológica", como "um modo de revisitar a relação das palavras com as coisas" (Castiel, 2004: 616), isto é, se é possível 'manuseálas' para delas se extraírem outros significados.

Em Páginas da Vida, ${ }^{6}$ novela de Manoel Carlos exibida em 2006 e 2007 pela Rede Globo de Televisão, que tem a SD como um dos principais temas abordados no enredo, são frequentes os diálogos em torno de tais categorias, muitas vezes usadas em substituição a pessoas com SD, num tom metonímico que tem a intenção de ser claro, mas que na verdade oferece outra face difusa.

Numa época em que o movimento é o aspecto fundamental e a velocidade com que as informações são processadas e difundidas torna impossível uma reflexão aprofundada sobre elas, as palavras utilizadas para nomear os fenômenos humanos parecem incapazes de abarcar os seus significados, tornando-se meras sombras fugazes, inapreensíveis, apenas deixando entrever aquilo que descrevem (Balandier, 1999).

O uso de determinadas palavras, como expressão formal de respeito pelo 'outro' e de afastamento do que o deprecia, tem como função preservar a fragilidade de certos equilíbrios. Diante dessa instabilidade, os novos mitos que prevalecem e que compõem o imaginário (Castoriadis, 2000) 
referem-se ao sucesso e à espetacularização da vida, ambos apoiados na figura do vencedor, personagem tornado sedutor por meio de numerosos artifícios e, por isso mesmo, vulnerabilizado (Balandier, 1999).

A exposição que é dada pela mídia às pessoas com $\mathrm{SD}$, ou apenas à SD, apoia-se nesses novos e frágeis mitos; dota as imagens de um caráter ambivalente, revelando o que é semelhante e, portanto, desejável, mas também aquilo que é inquietante e ameaçador.

\section{Capacidade e Movimento}

Ao se observar a imagem de Andrea Mantegna, deixando de lado o título da obra, vê-se uma mulher com um bebê no colo. Está vestida, tem a cabeça coberta por um manto, a fisionomia séria, o olhar baixo; o rosto inclinado para o lado toca com delicadeza a têmpora do bebê. Com uma das mãos segura o corpo enfaixado; com a outra, a cabeça pela parte de baixo do queixo, de forma a mantê-la segura. Difícil determinar sua idade, não parece nem jovem nem velha. Nota-se a presença de um bócio no pescoço, levemente encoberto pela sombra do queixo, indicativo de alguma disfunção da glândula tireoide.

O bebê está enfaixado, talvez um costume da época, talvez uma forma de contenção de um corpo que aparenta um tônus de um bebê de uns três meses, mas que não coincide com o seu tamanho, sugerindo uma hipotonia. Essa impressão surge da comparação entre o tamanho do bebê e o corpo da mulher (Cardoso, 2000). Tem os olhos fechados, dorme ou apenas descansa ao contato com a mulher. Deduz-se que seja ela sua mãe, em face do aconchego que se pode notar.

Andrea Mantegna é conhecido por sua precisão no tocante às proporções. Seu interesse pela Antiguidade Clássica influenciou fortemente seu trabalho, revelando-se no caráter quase escultural de suas pinturas. Crianças representando Jesus menino e anjos com características faciais sugestivas de SD são recorrentes em seus quadros, conforme foi observado por pesquisadores em diversos trabalhos (Stratford, 1982, 1996; Schwartzman, 1999), instigando a curiosidade quanto ao entendimento 
da sociedade da época sobre crianças com algum tipo de retardo mental. Ainda que alguns observadores considerem incertas tais correlações (Berg \& Korossy, 2001), o importante a ser aqui levado em conta diz respeito aos significados associados à SD decorrentes de tal hipótese que são difundidos tanto no círculo científico quanto no círculo não especializado, muitas vezes com o intuito de naturalização da síndrome e em outras de valorização de quem a apresenta.

Apesar de Mantegna ser considerado como um frio apreciador da Antiguidade, trabalhos como esse, em que é representada uma relação de intimidade entre Jesus e sua mãe, mostram um lado humano e caloroso (Manca, 2006). O caráter 'divino' das personagens tem repercussões importantes na construção social da ideia da pessoa com SD (Hacking, 2000), com a utilização da metáfora do 'anjo' como forma de lidar com o fato inexorável advindo de um 'acidente genético' (Cardoso, 2003), conforme se discutirá adiante.

Com base na leitura da narrativa não verbal veiculada pela imagem, o interesse em desdobrá-la em outras imagens possíveis levou à escolha da categoria isotópica 'tônus muscular', ancorada no aspecto físico, hipotonia, que chama a atenção para a SD: a cabeça da criança segurada pela mãe.

Para não cansar o leitor com o tom repetitivo que envolve a composição do quadrado semiótico, basta dizer que o processo seguiu o mesmo padrão da narrativa precedente. Os semas 'cabeça segurada' e 'cabeça erguida' são os termos que compõem a categoria isotópica escolhida para análise.

A categoria 'tônus muscular' assenta-se numa base físico-muscular, a frouxidão ligamentar, comum às pessoas com $\mathrm{SD}$, ainda que se manifeste de diferentes maneiras. O acesso de quem tem SD a um acompanhamento clínico adequado e às atividades e estímulos necessários ao seu desenvolvimento motor e cognitivo, contribuindo para melhor qualidade de vida, tem sido bastante enfocado e reforçado junto à população em geral e em particular às famílias que têm entre seus membros alguém com essa condição. Entretanto, os significados a ela relacionados extrapolam o 
âmbito corporal e abarcam esferas mais amplas, envolvendo capacidade, produtividade, identidade.

O ego-heroico, na acepção de Hillman (2002), é o modelo prevalente na cultura, considerado como padrão de normalidade. Valoriza o sucesso, a capacidade de adaptação à realidade e de superação de conflitos; é ativo, empreendedor, voltado à ação, inclusive corporalmente em termos musculares, apresentando-se sempre com tônus adequado.

Esse é o padrão, tal como um pano de fundo, contra o qual se deseja que as pessoas com SD sejam percebidas: prevalece a imagem única do indivíduo vitorioso, camuflada na forma de multiplicidade. Não é por acaso que uma das áreas de maior destaque relacionada a pessoas com SD é o esporte, nas mais variadas modalidades. Por intermédio da conquista de um 'tônus adequado' obtém-se uma identidade coesa, una, explicita-se a figura do campeão, do vencedor, como forma de compensar quaisquer outras habilidades sem o mesmo destaque, como o aspecto cognitivo, por exemplo.

Na sociedade ocidental, a cabeça pode ter seu significado ampliado para cérebro, mente, razão, raciocínio, cognição, e de certa forma configura uma sinédoque por se tornar representativa do ser humano, com a noção de que o cérebro é o mais importante órgão de uma pessoa (Ortega, 2006), em detrimento do sentido de totalidade corporal. A cabeça-razãocérebro ganha relevância pelo nível de comprometimento cognitivo presente que constitui uma das principais marcas da SD, em especial no tocante à frustração das expectativas dos pais em relação a um futuro produtivo para seus filhos.

Ser capaz de 'erguer a cabeça' ou necessitar que 'alguém a segure' refere-se não apenas a etapas do desenvolvimento físico de um bebê, que pode ou não sofrer algum atraso, mas à capacidade de se autodeterminar, de fazer escolhas, de se superar, enfim, de ter sucesso ou, caso contrário, ao ter que ser acompanhado e sustentado por alguém, de fracassar como pessoa autônoma, reforçando, com isso, posições duais.

A imagem resultante da análise da amostra de sangue, o cariótipo, revela o cromossomo 21 extra, tornando-se elemento material indispensável 
para os pais na construção da identidade do filho com SD. A definição da SD como um 'acidente genético' (no caso da trissomia livre, grande maioria dos casos), por um lado, minimiza o sentimento de culpa dos pais por gerar uma criança 'diferente', uma vez que a noção de 'erro' (que ocorre na divisão celular) evoca menos a afetividade do que as noções de 'doença' ou 'mal', apesar de sua relação com 'fracasso' (Canguilhem, 2002). Por outro lado, contribui para o que Dumit (1997) denomina automodelagem objetiva (objective self-fashioning), isto é, a configuração do self como categoria objetiva de pessoa mediante a propagação e a incorporação de fatos científicos.

Foucault (2006) utiliza a expressão 'jogos de verdade' para definir os jogos existentes entre o que é considerado verdadeiro e falso, que se desenrolam no contexto de práticas e relações específicas, e por meio dos quais o homem se pensa e se reconhece como sujeito. Tais jogos se conectam a determinadas tecnologias, entre elas as tecnologias do self que falam sobre como os indivíduos atuam sobre si mesmos - corpos, pensamentos, forma de ser - numa atitude de revelação de si através, principalmente, de verbalização resultando substancialmente na constituição de um novo self.

Nos debates sobre o modelo inclusivo, essa verbalização, que carrega resquícios de um modelo confessional religioso, é uma das principais atitudes: pais (ou familiares) de pessoas com SD fazem confissões sobre si e sobre seus filhos (ou parentes) com a intenção de constituírem um novo self capaz e vitorioso, e consequentemente para si mesmos como forma de amenizar o sofrimento e pela possibilidade de redenção, por vislumbrarem nos estigmas clinicamente característicos da face o estigma social do retardo mental. Depoimentos/confissões das próprias pessoas com SD são extensamente divulgados e contribuem não apenas para a abertura desse self publicamente, de se mostrarem como são, mas para a reafirmação a si mesmos daquilo que é dito sobre eles e é incorporado de forma a corresponder a determinados padrões de felicidade, sabedoria, pureza e perfeição. Tal atitude foi bastante explorada nos depoimentos no final de cada capítulo da novela Páginas da Vida, em que desfilaram numerosas famílias e pessoas com SD, entre outros, contando suas histórias e demarcando identidades. 


\section{Anjos Adultos}

A imagem retirada do documentário Do Luto à Luta e que foi usada na divulgação do vídeo corresponde ao momento da entrevista que o diretor faz com o casal. O plano adotado, que é definido pela distância entre a câmera e o objeto filmado, é um 'primeiro plano', o qual resulta de um enquadramento mais fechado cujo corte é na altura dos ombros da personagem, de forma a transmitir confiança e intimidade. Ele veste-se de preto, tem cabelos castanhos, curtos e olhos escuros; ela está de vermelho, seus cabelos são louros, compridos, e seus olhos, claros; ambos são brancos. Estão sentados de frente para a câmera, mas o olhar desvia-se um pouco para a direita (deles), na direção do entrevistador, em atitude atenta. A disposição horizontal com profundidade de campo permite a captura de informações no fundo: um vitral com a representação da Sagrada Família, que se localiza exatamente entre os dois. Em outro momento do filme, em planos mais abertos, percebe-se que a entrevista se dá no interior de uma Igreja católica. A entrevista se desenrola abordando temas comuns aos casamentos que seguem um padrão religioso, heterossexual, monogâmico, de família nuclear, entendida como instituição universal, cuja unidade é composta por pai, mãe e filhos, com divisão sexual de tarefas (Collier, Rosaldo \& Yanagisako, 1997). Mas o principal elemento subjacente à imagem, que a conecta à narrativa anterior (a pintura), diz respeito à metáfora do anjo citada anteriormente, aqui retomada para analisá-las.

Essa metáfora, revelada na pesquisa etnográfica realizada por Cardoso (2003) no Ambulatório de Genética Médica do Instituto Nacional de Saúde da Mulher, da Criança e do Adolescente Fernandes Figueira (IFF), uma unidade da Fundação Oswaldo Cruz (Fiocruz) voltada para assistência, pesquisa e ensino, surge nos relatos dos pais de crianças com SD, como forma de lidar com a realidade de se ter um filho que apresenta uma condição que o torna 'diferente'. O anjo é um ser inocente, especial, visto culturalmente como uma espécie de mediador entre o divino e o humano. Seu corpo apresenta uma importância secundária, inclusive com relação a características sexuais, minimizando com essa metáfora as dificuldades corporais apresentadas pelas pessoas com SD. No filme Tão Longe, Tão 
Perto (Faraway, So Close!), do cineasta Wim Wenders, lançado em 1993, os anjos, mensageiros sem poder de intervenção nas vidas humanas, são incapazes de perceber o mundo por meio dos sentidos, e quando um deles se torna humano, exatamente para poder se envolver em seus dramas e 'sentir', não consegue administrar as sensações e os julgamentos sobre o mundo e dos outros sobre si. No discurso de pais e pessoas que convivem com aqueles que têm SD, há uma evocação constante de aspectos sublinhados de religiosidade, fado, ensinamento ou transfiguração de algo essencialmente humano em quase divino.

A categoria isotópica sugerida pela imagem é 'tradição cristã' e inclui os semas 'ser celestial' e 'ser terreno'. O procedimento para o arranjo dos termos no quadrado semiótico é o mesmo das narrativas anteriores.

A pergunta feita ao casal, entrevistado junto com o diretor do documentário, no programa de televisão em canal por assinatura (GNT/ Globosat) Marília Gabriela Entrevista, no dia 27 de novembro de 2005, conecta-se a essa narrativa. A entrevistadora pede licença para fazer uma pergunta, que chama de "superparticular", ao casal: "A vida sexual de vocês é muito ativa?" O assunto já tinha sido abordado rapidamente quando, ao perguntar sobre o encontro dos dois, perguntara se a sexualidade era normal e se eles tinham "se guardado" para depois do casamento. Diante da falta de resposta direta sobre o assunto, notadamente por considerá-lo de forma diferente à da jornalista, representante nesse momento da sociedade 'normal', a pergunta foi refeita usando termos como "frequente", "muitas vezes", "sempre". Ter uma vida sexual ativa, 'normal', significaria eliminar as diferenças, igualar comportamentos, ações e reações. Entretanto, perguntar sobre isso traz implícito o reforço da estranheza, um tom quase de curiosidade sobre o que é exótico. Mas podem os anjos ter vida sexual?

Para conciliar a imagem do ser puro, transcendental, com a imagem do ser terreno, adulto, e que como tal realiza uma vida sexual e estabelece sua própria família, o filme implicitamente sugere a comparação com o padrão da família sagrada, sem mácula, cujo filho é gerado pela intervenção de um ser superior, antropomorfizado. O tom de superproteção que 
envolve pessoas com SD também está aqui presente, uma proteção divina, impedindo uma discussão aprofundada sobre os problemas e dificuldades cotidianos que envolvem a estruturação de uma família.

Qual o indício, o fio de Ariadne, que permite sair do labirinto em que a relação com as pessoas com SD (ou com a SD) está? Quando o 'um' se desdobra, o 'múltiplo' se revela.

Olhar com estranhamento crítico a imagem prevalente dessas pessoas permite o surgimento das múltiplas imagens encobertas, rompendo com a ilusão de que elas compõem um grupo homogêneo, como se quer acreditar, mas que formam um grupo complexo em suas habilidades, capacidades e limitações.

O contágio e a invasão de um corpo saudável por elementos hostis são preocupações da medicina ocidental que se amplificaram nos discursos relacionados à expansão colonialista e às relações entre culturas e indivíduos. Segundo Haraway (1991), o sistema imunológico tem sido uma importante linguagem utilizada no contexto da biopolítica ocidental para tratar a 'diferença', estabelecendo limites entre o que é considerado como 'mesmo' e 'outro', definindo o que é normal e o que é patológico. Abarca tanto uma dimensão técnica quanto uma dimensão mítica como analogia para discutir as diferenças simbólicas e materiais presentes na cultura capitalista atual. Reconhecimento e estranhamento do 'eu' e do 'outro' são ações fundamentais desse sistema.

O 'outro' pode ser não apenas aqueles 'elementos externos invasores' contra os quais o sistema imunológico deve defender o 'eu', mas os próprios 'estranhos' existentes em cada 'eu', por meio dos quais é possível manter a integridade e a individualidade dos corpos diante de um mundo repleto de 'outros' (Haraway, 1991).

No tocante à $\mathrm{SD}$, o discurso imunológico permite outro olhar por suscitar reflexões a respeito de quem são o 'eu' e o 'outro', de como a sociedade lida com seus próprios 'estranhos' no sentido do que pode ser incorporado ou do que deve ser rechaçado. As pessoas com SD, que de alguma forma assimilam as expectativas da família e da sociedade sobre si mesmas, ou a ideia que se construiu sobre elas, tentam com maior ou 
menor esforço e sofrimento corresponder ao esperado, por meio de um discurso de reafirmação constante da inexistência de qualquer limite, que ganha contornos cada vez mais desproporcionais.

Mascarar a existência de limitações chama a sociedade para a uniformidade, para o mesmo, reforça o ideal do corpo capaz como base para a definição do humano e traz apaziguamento às angústias relacionadas ao que não corresponde a esse ideal de capacidade.

Essa entrada de voz 'canta' a SD na tonalidade da diferença. Ao escutá-la, percebe-se que um novo velho mito, no sentido barthesiano, está sendo criado: a afirmação da diferença, que subliminarmente reforça o modelo ocidental moderno da normalidade, no qual o 'mesmo' corresponde ao ideal iluminista de ser humano autônomo.

\section{NotAs}

1 O termo 'letramento', versão da palavra literacy, na língua inglesa, foi usado pela primeira vez no Brasil por Kato (1986) e por Tfouni (1988), sendo retomado em publicações posteriores. O uso do termo letramento na educação amplia o sentido dado à alfabetização, envolvendo não apenas a apropriação de um código, mas o conjunto das práticas sociais que utilizam a escrita como ferramenta tecnológica e como sistema simbólico (Soares, 2003). Neste livro, a utilização do termo se refere à presença do conhecimento especializado sobre SD no discurso leigo e às habilidades para dele fazer uso.

2 Música escrita por Mac Davis e Billy Strange e gravada por Elvis Presley em 1968. Título em português: Um Pouco Menos de Conversa.

3 Segundo o Dicionário Houaiss (Houaiss, Villar \& Mello Franco, 2004: 364), o azul tem o sentido figurado de "tudo em ordem, em paz, às mil maravilhas", mas também de "muito assustado, muito perturbado (ficar a.)".

4 A expressão "condições alteradas" foi extraída por Epstein (1995) de Rudolf Virchow, patologista alemão que, em 1847, se referiu à doença não como organismo autônomo, externo ao corpo, mas como sendo o curso de fenômenos fisiológicos em condições alteradas. Para ele, segundo Epstein (1995), a diferença entre saúde e doença seria uma alteração de condições e não de essência. No caso da SD, a trissomia do cromossomo 21.

5 Conhecido como shaka sign, esse gesto é comumente associado ao Havaí e ao surfe. Não existe um significado único, mas de modo geral é usado como forma de saudação e também com o significado de concordância ou apreciação de algo como 'legal'. O 
mesmo gesto, ao se posicionar o dedão junto ao ouvido e o dedo mínimo perto da boca, pode significar 'me liga' ou 'eu vou ligar para você'.

6 A telenovela, escrita por Manoel Carlos e colaboradores, com direção de núcleo de Jaime Monjardim, foi exibida no horário nobre da emissora entre julho de 2006 e março de 2007, num total de 203 capítulos. Além dos elementos de sempre escolhidos pelo autor - uma personagem chamada Helena, o bairro do Leblon, no Rio de Janeiro, temática social e conflitos humanos -, a produção tem como eixo central a SD; outros temas como bulimia e Aids também são abordados. Uma jovem é abandonada grávida pelo namorado em Amsterdã, onde estuda, e é obrigada a voltar ao Brasil em busca de apoio da família. Culpabilizada pela mãe, ela morre ao dar à luz gêmeos, um deles com $\mathrm{SD}$, o qual é entregue secretamente em adoção para a médica que fez o parto e dado como morto. O elenco conta com Regina Duarte, Fernanda Vasconcellos e Lília Cabral, entre outros. 


\section{SEguindo Episódio: \\ CRIANCAS PARTIDAS, CRIANCCAS \\ PERFEITAS OU AS LAGOSTAS AZUIS}

Toda prática científica é, em certa medida, uma prática narrativa relacionada a formas de interpretação e visões de mundo que se modificam historicamente e que dão sentido aos novos desenvolvimentos tecnocientíficos.

Os avanços científicos são acompanhados por imagens e imaginação; um construto científico está muitas vezes associado ou mesmo baseado numa imagem reconhecida como desejável ou familiar. Diferentes grupos, especializados ou não, utilizam ambas, imagens e imaginação, na construção e busca por validação dos seus debates em torno do campo da ciência em geral e da genética, em particular. Novas tecnologias requerem novas imagens e novos elementos no processo imaginativo. Entretanto, tais reformulações não acontecem facilmente, muitas vezes prevalecendo uma releitura de antigas imagens (Van Dijck, 1998). O uso de linguagem figurada abre novas perspectivas, por sua flexibilidade e imprecisão, para clarificar fenômenos, cuja novidade se faz sentir na ausência de palavras para descrevê-los.

O conhecimento genético que é disseminado está entremeado por fantasias de um futuro promissor, com novas esperanças e expectativas de controle, mas que ao mesmo tempo infunde medo diante do imprevisível e desconhecido, e é revestido por um alto teor de apelo dramático, por meio de imagens ou histórias narradas. 
Este segundo episódio discute livros e blogs escritos e produzidos por pais de pessoas com síndrome de Down (SD). Apesar de serem relatos de histórias 'reais', isto é, não ficcionais, contêm elementos narrativos que reproduzem as mesmas imagens e componentes imaginativos de produções tanto científicas quanto ficcionais. Acaso e determinismo, capacidade e configuração genética, identidade biológica e social são alguns dos aspectos presentes nas narrativas analisadas.

A entrada de voz dá respostas ao tema principal e à primeira voz, reafirmando-as; contudo, deixa entrever dissonâncias e ambivalências, harmonizadas por meio da variação contrapontística.

\section{Construção Pública do SelF}

O contexto da genética, analisado por José Van Dijck (1998) por meio da utilização da metáfora do teatro, envolve uma dose de dramatização, de apelo emocional, que é necessária à disseminação dos seus conceitos e debates. Personagens (cientistas, geneticistas), enredos (de aventura, de detetives ou de competição) e metáforas (genoma como mapa, gene como código, só para citar as mais comuns) são os principais instrumentos narrativos na atuação do teatro da genética, os quais se articulam às referências que o público em geral faz a esse campo, bem como à dinâmica de produção de sentidos.

Em vez de um modelo linear de difusão do conhecimento científico, Van Dijck, com essa metáfora, reforça a circularidade como predominante, aspecto já enfatizado por outros autores como Ludwik Fleck (1981), que enfoca o entrelaçamento existente entre o conhecimento gerado no círculo científico ou esotérico e o que circula na comunidade leiga ou círculo exotérico, e Carlo Ginzburg (2002), que usa a expressão 'circularidade de ideias' para desfazer a noção de que as informações originadas no círculo especializado são distorcidas ou sofrem deterioração ao serem assimiladas pelo círculo leigo.

Os livros e blogs analisados, apesar de pertencerem a contextos culturais diferentes, ainda que ocidentais, apresentam um conteúdo que não 
difere substancialmente, não apenas porque a SD independe de etnia, cultura ou nível socioeconômico, mas também porque na era genômica as identidades individuais transcendem as fronteiras nacionais para se conformarem como identidades essencialmente biológicas, moldadas por características vitais específicas.

Nas narrativas, o individual se entrelaça ao social; são relatos particulares, experienciais, mas que formam parte de um mesmo gênero que as engloba, o gênero confessional, e que têm como contexto mais abrangente a presença de uma condição genética específica, a SD. Tais práticas sociais servem ao propósito de construção, abertura e exposição de um novo self, em que a experiência vivida é o mais importante.

Com a frase 'meu filho tem SD' começa a construção de uma identidade pautada pelo somático, que se a princípio é exposta nos sinais aparentes na superficialidade do corpo, adiante é materializada na abstração do construto do cromossomo 21 extra, ao qual os pais têm acesso via cariótipo representado num papel impresso, e que (re)interpreta a pessoa em sua própria corporalidade.

Narrar é uma característica comum aos seres humanos. Narrar experiências por meio de livros ou blogs contribui para tornar o estranho familiar, a fim de dar significado ao vivido e sentido. Além do suporte emocional proposto, as narrativas têm a intenção de apresentar ou facilitar caminhos para, em termos práticos, tornar menos traumática a convivência com a presença da SD no filho, estimulando a busca por informação e por intervenções cada vez mais precoces.

Na grande maioria dos casos, a exposição é feita por pais ou parentes de pessoas com SD, mas também existem narrativas feitas por essas próprias pessoas. Os elementos principais de tais discussões são os desafios e conflitos enfrentados quando no momento do diagnóstico, seja ele feito ao nascer, seja ainda durante a gestação, e o processo de criação de um filho com SD, com dúvidas, questionamentos e necessidades de decisões relativas a um futuro que se apresenta incerto.

Transmitir experiências a outras pessoas com vivências semelhantes ou não cria uma forma de identidade compartilhada que une uma 
audiência, anônima em sua maioria, e que se traduz numa espécie de parentesco que acolhe, apoia, estimula e compreende o que antes era impensável. Concomitantemente, essas experiências se espraiam, tecendo redes que atuam como verdades plurais, gerando controvérsia, dúvida e questionamento em relação ao discurso biomédico, tornado monólogo.

A construção de narrativas por pacientes e famílias como forma de lidar com a presença de uma condição crônica específica que acarreta uma quebra nas suas vidas, com consequente alteração de identidade, foi alvo de estudo de vários autores desde a segunda metade do século XX. Um desses autores, Anne Hunsaker Hawkins (1999), utiliza o termo patografia para definir um gênero de narrativas no qual uma experiência profundamente traumática e destrutiva relacionada ao adoecimento é relatada, bem como as alternativas encontradas para com ela conviver e de algum modo transformá-la em uma experiência restauradora.

As narrativas em SD analisadas se aproximam em alguns aspectos das patografias estudadas por Hawkins (1999), especialmente no seu caráter de suporte diante de uma situação de adoecimento que se apresenta como desconhecida e ameaçadora da integridade de uma pessoa, e na identificação de elementos metafóricos comuns utilizados para descrever a experiência e lhe dar sentido.

Contudo, outros aspectos as diferenciam: em primeiro lugar, por ser a SD uma condição que já está manifesta ao nascer, não existe quebra no processo de vida da criança, isto é, um antes e um depois da SD, por mais que intercorrências graves, como uma cirurgia, por exemplo, funcionem como marcos importantes. A quebra se dá na vida das pessoas à sua volta, especialmente dos pais. Em segundo lugar, o fato de que, apesar de profundamente traumática a princípio, a experiência de ter um filho com SD é relatada como definitivamente compensadora para as vidas das pessoas envolvidas.

Os eventos escolhidos para serem registrados, mais do que vivências individuais, são expressões de um determinado grupo, uma vez que a seleção do que vai ser lembrado (e como) e daquilo que não vale a pena ser registrado como evento marcante é função também de uma importância incorporada 
socialmente. Os livros e blogs, produtos desses registros, tornam-se atos culturais coletivos e, muitas vezes, são resultado de uma indústria da memória que se alimenta dessas narrativas, sejam elas livros, sejam filmes, fotografias ou outros objetos de memória.

Recordar não é trazer um passado estocado e pronto, mas reatualizar experiências quando evocadas. Lembrar para registrar modifica a experiência vivida por seu aspecto seletivo, mas também pelas novas cores e interpretações dadas a emoções e reflexões após sua vivência. Registrar, portanto, é também criar. Da mesma forma, ler é uma forma de reescrever. Nas palavras poéticas de Gabriel García Marquez (2003), "la vida no es la que uno vivió, sino la que uno recuerda y cómo recuerda para contarla". ${ }^{1}$

No processo de memória e recontagem das histórias em SD, a realização dos testes pré-natais - em especial aqueles que fornecem imagens, como as ultrassonografias (USG) feitas nos diferentes trimestres, com a medida da translucência nucal (TN) para avaliação do risco de anomalias cromossômicas no primeiro trimestre; a morfológica para avaliação do crescimento, desenvolvimento e das estruturas fetais no segundo; e as USGs 3D e 4D $-^{2}$ forma parte dos ritos compartilhados que são narrados e criam memórias anteriores ao nascimento que começam a compor o álbum do bebê e a embalar as expectativas e fantasias com relação a ele.

Quando essas imagens revelam algo diferente, que não está de acordo com uma norma reconhecida socialmente como desejável, outras emoções são acrescidas a esses eventos. Novos testes, como a biópsia de vilo corial, a amniocentese e a cordocentese, por exemplo, são realizados na busca por transformar possibilidades em respostas. Tais memórias mediadas a um só tempo moldam e são moldadas pela mídia utilizada no seu registro - no caso, os livros e blogs.

\section{ERA UMA VEZ...}

As narrativas em SD na forma de livro se multiplicaram a partir dos anos 80, numa tendência crescente de lançar luz sobre o que era a SD e, principalmente, trazer da sombra as pessoas que com ela nasciam. $\mathrm{O}$ declínio do uso do termo 'mongolismo', cujo caráter pejorativo foi sendo 
cada vez mais criticado, e a sua substituição pelo termo síndrome de Down ou trissomia do 21 impulsionaram a sociedade para uma discussão mais abrangente sobre o assunto.

Contudo, não obstante as diferenças culturais, os semas presentes nas narrativas são similares, bem como a mitologia que as embasa, aqui entendida, de forma ampla, como um conjunto de relatos simbólicos que narram e explicam a origem de determinados fenômenos (Henderson, 1996).

A análise dos relatos destaca a existência de uma estrutura narrativa comum, com personagens, ações específicas, partes constituintes, desenlaces. Alguns relatos seguem o sintagma narrativo básico, o modelo temporal linear equilíbrio-ruptura-equilíbrio. Outras apresentam um desdobramento dessa estrutura básica, comparável ao esquema em cinco partes desenvolvido por Tzvetan Todorov (1969) em sua poética estruturalista sobre o aspecto sintático do texto. Esse esquema é composto de três momentos estáticos (1, 3 e 5) e dois dinâmicos (2 e 4), e as relações são predominantemente sequenciais ou temporais: 1) situação inicial (que descreve a vida antes da chegada da criança até os momentos iniciais da gravidez); 2) perturbação da situação inicial (a suspeita de que algo não é como o esperado); 3) desequilíbrio ou crise (o diagnóstico); 4) intervenção na crise (a busca por informação ou grupos de suporte, a partir da qual a situação começa a mudar); 5) novo equilíbrio (semelhante ou não à situação inicial).

Nos relatos, a sequência da narração pode ou não ser cronológica e na maioria das vezes não o é -, mas os momentos são identificáveis, implícita ou explicitamente; o ponto de corte é o nascimento ou o diagnóstico via USG.

Observa-se a presença de relações espaciais não apenas nas imagens, mas evocadas também nos textos escritos, incluídas nas relações sequenciais, eixo sintagmático (Sausurre, 1983): dentro/fora (um processo interno ou externo ao indivíduo), perto/longe (a sensação de estranhamento vivenciada pelos pais em relação a seus filhos com SD), frente/trás (pensamentos que aparecem em primeiro ou segundo plano e que carregam não apenas a noção temporal de simultaneidade, mas espacial, diferenciando o 
que acontece de forma involuntária e intencionalmente) são aspectos relacionais observados cujos atributos não são de forma alguma neutros.

No eixo paradigmático ou associativo (Saussure, 1983), os significados foram identificados e analisados em contraste com aqueles ausentes que poderiam ter sido usados. A separação das narrativas em cinco grupos se deve a uma opção de organização do material de acordo com o enfoque priorizado em cada grupo. São elas: narrativas de fé, de presentes, de perda, de jornadas e de capacidades.

As narrativas de fé que compõem o primeiro grupo equivalem àquelas conhecidas como narrativas 'triunfo-sobre-tragédia', nas quais a deficiência é suplantada de forma heroica (Gray, 2009). São exemplificadas pelo livro Common Threads: celebrating life with Down syndrome, ${ }^{3}$ de Cynthia S. Kidder e Brian Skotko, publicado em 2007, composto por 68 pequenas histórias, algumas na forma de poemas, e fotografias não correspondentes aos relatos, que narram um episódio pontual na vida de pessoas com SD. Essas histórias foram coletadas, selecionadas e reescritas para compor o livro de acordo com o tema proposto no título, em que o fio comum é a fé. De modo geral, o relato parte de um fato recente, difícil de acreditar, aceitar ou mesmo de viver, que marca o ponto de corte da narrativa e, em retrospecto, conta como a pessoa viveu tal situação. São narrativas expectantes, com emoção e suspense, elementos capazes de capturar a atenção do leitor. Não são histórias de dores, e sim histórias para celebrar, uma vez que a construção dos relatos invariavelmente se traduz num quadro de sucesso, mesmo quando as condições apontam o contrário. As dificuldades são cuidadosamente descritas para dar perspectiva àquilo que precisa ser vencido; o texto parte dos obstáculos para a superação.

As imagens de caráter artístico, especialmente aquelas em preto e branco, são oníricas, angelicais, o que é sugerido pelo desfoque dos pés, pela vestimenta, pela luz: as crianças não estão 'plantadas' no chão, mas quase etéreas, flutuantes, em roupas brancas e rendas, como que em outra dimensão, outra humanidade. A convivência harmoniosa consigo mesmas, com os outros e com a natureza dá a tônica. A luz incidindo nos cabelos, na cabeça, torna-as iluminadas por uma pureza celestial, divina, 
contemplativa e pacífica, que também evoca a luz da razão, porém uma razão diferente, pura e completa, livre das amarras da imperfeição humana, o que se acentua com a presença de fenótipos pouco marcados.

O olhar frontal, encarando a câmera (ou o fotógrafo detrás dela e o leitor), exala segurança na exploração do mundo, desejo de sociabilizar, mostrando quem e como é.

As narrativas são intercaladas com resumos de pesquisas, narrados de forma a ressaltar o potencial de capacidade das pessoas com SD. Na maioria delas, é reportado que não há diferença significativa entre elas e o grupo usado como controle, tendo o pareamento sido feito de acordo com a idade mental - ou seja, as pessoas com SD são comparadas em termos de desenvolvimento com pessoas cronologicamente mais novas. Tais pesquisas testificam os eventos como extraordinários, reafirmando o ser especial e a capacidade dessas crianças em relação às outras. Segundo o livro, fé e ciência dão as mãos, uma justificando a outra. Dessa forma, propõe-se informativo ao veicular um conhecimento científico sobre o assunto, suportando pela fé aquilo que é conhecimento.

O livro é considerado um coffee table book, isto é, um livro que é para ser exibido, apreciado artística e visualmente porque, conforme dito na introdução, não é sobre a diferença, mas sobre a celebração de vidas felizes. Contraditoriamente, o texto termina com uma frase confirmando a diferença como responsável por enriquecer a vida de todos.

A figura do vencedor e o episódio da conquista tornam-se fatos. Quase todas as situações narradas envolvem algum tipo de competição ou prêmio; não basta fazer algo, é preciso ser vitorioso, materializar e tornar literais os desafios, que são colocados no lugar daquilo que precisa ser suplantado, a própria SD. Não apenas a pessoa é excepcional, exceção, diferente da regra, mas também a família. Tais conquistas contribuem para estabelecer a identidade coesa de um indivíduo autônomo.

As narrativas de presentes compõem o segundo grupo. O livro Gifts: mothers reflect on how children with Down syndrome enrich their lives, ${ }^{4}$ editado por Kathryn Lynard Soper em 2007, é um exemplo desse tipo de narrativa, no qual o elemento comum é a afirmação de que a convivência com uma 
criança que tem SD é algo para se celebrar como um presente. São 63 narrativas distribuídas em cinco presentes: respeito, perspectiva, deleite, força e amor. São relatos sobre a crise que se segue ao diagnóstico de SD para um filho; confissões sobre medos, fraquezas, preconceitos; confissões públicas para um público, perdão e reconhecimento da culpa e 'pecado' pela não aceitação ou rejeição da criança. As fotografias associadas são em preto e branco, em sua maioria retratos das crianças com SD, mas também destas e de suas mães ou mesmo da família (pais e irmãos).

Nos primeiros momentos da crise (que podem ser dias, meses), a criança pertence mais ao médico, com seus jargões, nomes de doenças ou complicações, do que aos pais, que se sentem intimidados ante o inesperado. Diante de tantos agravantes, a SD aparece como 'apenas' SD ou 'apenas' um cromossomo extra. A expectativa pelo resultado do cariótipo se traduz como a espera pela 'verdade natural' do bebê, que nesse momento soa como fado. A confirmação do diagnóstico, a princípio, impossibilita o reconhecimento daquele bebê como filho. A criança é vista ora através do olhar cromossômico, como trissomia do 21, ora através de ideias e imagens preconcebidas que tomam o espaço e impedem o contato com quem aquele bebê é, muitas vezes ofuscando qualquer outra manifestação clínica não associada à SD. Os jargões são incorporados, os nomes dos exames e das intercorrências e suas siglas passam a fazer parte do vocabulário dessas vidas.

Coragem, determinação e capacidade de luta pela vida surgem nas narrativas como inerentes a essas crianças e 'como se' conscientes, o que faz os pais se sentirem capazes também. Aqui não aparece o sema 'vencedor' ou 'campeão' no sentido materializado, mas sim figurado, pela capacidade de transpor tantas dificuldades, em sua maioria médicas.

O terceiro conjunto é formado por narrativas de perda, cujo foco é o sentimento que surge quando da morte do filho idealizado e dos sonhos a ele associados e do nascimento de um bebê com SD. O livro que ilustra esse tipo de narrativa é You Will Dream New Dreams: inspiring personal stories by parents of children with disabilities, ${ }^{5}$ de Stanley D. Klein e Kim Schive, publicado em 2001. As narrativas englobam diversos tipos de deficiência, 
entre elas a SD. Pais veteranos foram estimulados a escrever a pais novatos mensagens que gostariam de ter ouvido no momento do nascimento do filho. Validação, afirmação, suporte e encorajamento evidenciam-se nos textos. Centenas de pais enviaram suas histórias, e 63 foram selecionadas, sendo 18 sobre SD. São uma espécie de conversa, na qual o interlocutor é o público potencial. Escutar os relatos é considerado como essencial, mas como isso não é possível, as palavras escritas poderão ser de ajuda. Por serem pais há mais tempo, nota-se que as memórias já estão suavizadas, pois a descrição da crise em muitas histórias já não é mais traumática.

Entre elas, encontra-se o texto "Bem-vindo à Holanda" ("Welcome to Holland"), de 1987, escrito por Emily Perl Kingsley (Klein \& Schive, 2001), o qual se tornou amplamente conhecido, inclusive no Brasil, e que tem sido distribuído como parte do material informativo fornecido por hospitais aos pais quando do nascimento de um bebê com SD. Nele, a experiência de ter um filho com deficiência é comparada à decepção e à frustração advindas da mudança de roteiro numa viagem de férias, em que o lugar desejado (Itália) é substituído por outro (Holanda), ressaltando a importância de se vencerem tais sentimentos para então começar a se descobrirem as coisas boas do novo roteiro. Essa história é citada por muitos pais como tendo sido de grande valia no processo de aceitação do filho com a condição, e a Holanda passou a ser usada como metáfora para a SD.

Em versão ligeiramente modificada, as tulipas azuis (cuja cor em realidade se aproxima mais do violáceo, não existindo uma 'verdadeira' cor azul) da Holanda emergem como significativas e contrastam com as rosas vermelhas de Florença, na Itália, tornando-se metáforas para as conquistas (que também evocam fracassos) das pessoas com SD. Contudo, os dois países usados como roteiros, apesar das diferenças culturais estereotipadas - um mais caloroso, vibrante e desejável do que outro -, ainda assim pertencem a um mesmo contexto europeu que talvez não seja capaz de traduzir as angústias, inseguranças e dificuldades de acesso a serviços públicos existentes em países como o Brasil, e que em sentido figurado podem se aproximar do lugar horrível, desagradável e cheio de doença a 
que Emily Perl Kingsley se refere como aquele ao qual 'poderiam' mas, felizmente, 'não foram' levados.

O momento do diagnóstico dificilmente é esquecido. Numa das narrativas, a mãe ainda na sala de parto segue de perto o médico numa espécie de "dança surreal" (Klein \& Schive, 2001: 137), uma inspeção cuidadosa no corpo do bebê em busca de outros sinais que confirmem a SD. O silêncio toma conta do espaço, torna-se quase palpável, e o tempo para à espera de uma palavra ou duas sobre aquilo que ela já sabe. Sentimentos de solidão e de luto predominam, mesmo quando família e profissionais estão presentes para dar suporte, e equivalem à dor que advém da morte 'concreta' da criança. Contudo, é imperativo continuar vivendo. As atitudes diante do nascimento de um filho com SD são semelhantes às experienciadas no processo de aceitação de uma doença terminal, conforme descrito por Elizabeth Kübler-Ross (1985): negação e isolamento, raiva, barganha, depressão, aceitação. Os diferentes estágios têm duração variável, podendo ser consecutivos ou simultâneos. Não existem respostas fáceis ou prontas, mas aos poucos é possível descobrir novas formas de conviver com a situação de maneira mais proveitosa. O desapontamento e a angústia sentidos equivalem a uma ferida que só gradualmente será curada. O ponto de mudança é quando esses pais podem escutar as histórias de outros com experiências semelhantes. É possível ser feliz novamente, descobrem; sonhos morreram, o filho idealizado também. Entretanto, novos sonhos serão sonhados.

As narrativas de jornadas compõem o quarto conjunto. São livros com histórias individuais, tais como Cadê a Síndrome de Down que Estava Aqui? O gato comeu...: o programa da Lurdinha, de Elizabeth Tunes e L. Danezy Piantino (2006); Meu Rei Arthur, de Lúcia Cyreno (2007a); O Filho Eterno, de Cristovão Tezza (2007); Down (Syndrome) but not Out: a journey from grief to joy, ${ }^{6}$ de Joyce Sampson (2007); e Road Map to Holland: how I found my way through my son's first two years with Down syndrome, ${ }^{7}$ de Jennifer Graf Groneberg (2008). 
Por serem mais longas, essas narrativas contêm mais detalhes no tocante à vida dos seus autores, ainda que o fio condutor seja a presença da SD. Algumas reproduzem o processo de desenvolvimento do filho, as terapias realizadas, os programas de estimulação precoce, os momentos de aflição, tristeza, decisão, alívio. Uma delas, O Filho Eterno, de autoria do escritor catarinense Cristovão Tezza (2007) e ganhador de vários prêmios literários em 2008, destaca-se pelo nível de elaboração estética e por apresentar uma forma diferenciada de reflexão confessional, que revela uma faceta mais crua e crítica do que é ter um filho com SD. O relato trata basicamente das reflexões do personagem principal e sua 'jornada' (às vezes externa, mas muito mais interna) a partir do nascimento de seu filho no início dos anos 80, quando o tema ainda não era amplamente discutido e poucas eram as alternativas para se lidar com o fato. Ao mesmo tempo que autor e personagem se confundem, há um certo distanciamento ficcional, resultado do trabalho literário do autor, que torna o relato menos autobiográfico. $\mathrm{O}$ título, se por um lado resume um aspecto vivenciado pelas pessoas com SD, qual seja a dificuldade de abstração que permita incorporar a noção de tempo, ou a ideia de passado e futuro, tornando a experiência diária um eterno presente, por outro reafirma a imaturidade dessas pessoas e a sua necessidade de suporte.

Por fim, o quinto conjunto organiza-se como narrativas de capacidades, na forma de histórias voltadas para o público infantil, no sentido de apresentar o que é a SD e de chamar a atenção de crianças (e adultos) sobre a convivência com essas pessoas. Entre essas histórias estão os livros Where's Chimpy?, ${ }^{8}$ de Berniece Rabe (1988); a Coleção Meu Amigo Down, de Claudia Werneck (1994); Um Amigo Diferente?, também de Claudia Werneck (1996); We'll Paint the Octopus Red, ${ }^{9}$ de Stephanie Stuve-Bodeen (1998); Our Brother Has Down's Syndrome, ${ }^{10}$ de Shelley Cairo (1999); I Can, Can You?, ${ }^{11}$ de Marjorie W. Pitzer (2004); O Pequeno Rei Arthur, de Lúcia Cyreno (2007b); e Mi Amiga Tiene el Síndrome de Down,, ${ }^{12}$ de Jennifer MooreMallinos (2008). São relatos sobre a chegada do novo irmão, filho, vizinho ou colega de escola que tem SD. A preocupação presente nos livros é 
quanto à capacidade de realização da criança: o que ela pode ou não fazer e quando. Nota-se um esforço no que se refere à redefinição dos limites na SD que indiciariamente reforça um olhar de estranheza em relação a essas pessoas e seu desenvolvimento.

\section{"Ulm Blog se Alimenta DOS SEUS COMENTÁRIOS..."}

$\mathrm{Na}$ era digital, a possibilidade de compartilhar e de se comunicar instantaneamente transforma as práticas culturais de preservação de memórias e de trocas de experiências. Novas tecnologias contribuem para o surgimento de novas formas de construção e modelagem do self, como, por exemplo, os blogs.

Blogs têm múltiplos antecedentes. Um deles é o termo log utilizado na linguagem naval, que consiste num dado cronológico atualizado periodicamente e necessário à navegação. Assim, sua utilização torna-se condizente com as imagens metafóricas aplicadas à Internet, sugerindo dados de uma jornada que pode ser significativa para outras pessoas (Miller \& Shepherd, 2004).

Os diários em papel, formas culturais entendidas como privadas, mas que sempre contiveram um aspecto de compartilhar, ainda que com uma audiência restrita, foram em certa medida substituídos pelos lifelogs, seu correspondente digital, embora não coincidentes em sua totalidade. Os lifelogs visam ao compartilhamento de experiências e subjetividades, mais do que à expressão individual ou à reflexão, como poderia ser entendida a função dos antigos diários (Van Dijck, 2007). Neles, o proprietário (ou autor) faz - ou posta, numa analogia com o correio - atualizações regulares, que podem seguir um tema específico, eventos ou pensamentos e reflexões. Existe ainda espaço para comentários dos leitores diretamente no blog ou por e-mail, permitindo o contato com o autor e com outros leitores, além de links para diferentes websites (Blanchard, 2004).

No âmbito do fenômeno dos blogs, a interseção entre as dimensões pública e privada é redesenhada: ao mesmo tempo que o blog é um espaço 
confessional cujo caráter do conteúdo é basicamente pessoal, busca ser reconhecido como parte de uma comunidade (Badger, 2004; Van Dijck, 2009). O público ao qual se dirige pode ser qualquer um, mesmo no caso daqueles voltados à discussão e à divulgação de experiências de famílias em que está presente uma condição genética como a SD. A sua ampla expansão parece relacionar-se não apenas às crescentes facilidade de acesso à rede e disponibilidade de tecnologias digitais de fácil manuseio e mais baixo custo, mas também à necessidade de se comunicar algo que de outra forma não seria possível.

A noção de blog torna menos delimitada a fronteira entre autor e leitor, na medida em que permite um canal de manifestação de dupla via, criando uma sensação de envolvimento, além de possibilitar ao leitor uma reordenação da narrativa de numerosas formas (Himmer, 2004). Diferentemente dos livros, nos blogs a ênfase recai sobre o processo mais do que sobre uma posição definida e fechada; a instabilidade é maior, e as mudanças de perspectiva ou mesmo de opinião podem emergir mais facilmente.

Nos blogs analisados, o intervalo entre uma entrada (post) e outra varia de acordo com os autores ou com o momento de vida de cada um; os assuntos abordados, em geral, tratam de temas ligados ao processo de desenvolvimento da criança com SD - as dificuldades clínicas, os preconceitos e, principalmente, as conquistas diárias, seja na escola, seja nas várias atividades de estimulação a que é submetida rotineiramente. As fotografias associadas são instantâneos capturados pela lente amorosa de pais e familiares e servem mais como registros a serem compartilhados do que como preservação de memória.

Predominantemente, os blogs são criados a partir do fato de se ter um filho com SD e são escritos por mães em primeira pessoa, e alguns pais, mas também 'como se' dando voz ao(à) filho(a) com SD. Narram episódios familiares, mas, sobretudo, texto e imagem são dispostos com o propósito de dar a conhecer quem são os membros dessa família, como é e como vive alguém que tem SD.

Ainda que muitos utilizem pseudônimos, transparece uma forma de se manter compromisso com a 'verdade', reforçado pela exibição livre 
das fotografias; de confessar as fraquezas, as rejeições e os medos; de não esconder o sentido e o executado, pois cada uma dessas ações ou emoções pode ser de ajuda para outros pais. ${ }^{13}$

Cada blog traz referências a outros blogs escolhidos como parte de um grupo que compartilha aspectos comuns, num desdobramento que tende à circularidade, manifesta no entrecruzamento das referências e do material informativo, como livros, entrevistas e reportagens.

Nos blogs, as relações sequenciais no eixo sintagmático evidenciam-se primordialmente na cronologia, ainda que inversa, das entradas (as novas entradas e a respectiva hora de postagem são incorporadas no topo da página) e criam a noção de continuidade da narrativa, gerando expectativas e envolvendo o leitor em acontecimentos de vidas que não a sua, mas que de certa forma refletem aspectos comuns, tornando-os significativos. São observadas também na ordem escolhida para dispor as imagens, podendo compor uma narrativa em separado. A inversão cronológica sugere ainda uma proximidade com a experiência presente do autor, que reforça a ideia do relato como não ficcional.

As relações sintagmáticas espaciais incluem aspectos como acima/ abaixo, esquerda/direita, figura/fundo, salientando ora texto, ora imagem. A presença e a distribuição dos elementos visuais - a divisão da tela em colunas, o uso de imagem e cor, a escolha de caracteres e fontes possibilitam uma leitura não verbal do material frequentemente mais abundante em significados do que a parte verbal (Miller \& Shepherd, 2004).

Apesar da grande variedade de formas e cores que servem à individualização, de modo geral os elementos constituintes dos blogs são: textos que seguem o formato de diário e podem se localizar tanto à direita quanto à esquerda na tela; espaço para comentários (por exemplo, um ícone de um polvo com extensões semelhantes a raízes e galhos, ou de um dinossauro, com a mensagem-convite de que "un blog se alimenta de tus comentários"), reforçando a ideia de conectividade e interatividade; fotos de vários eventos (férias, aniversários, nas várias terapias, na escola, em casa...); vídeos; calendário; hora (relógio nos mais variados formatos); contagem dos aniversários; contador de visitas; dados pessoais da criança e 
dos pais; arquivo com as entradas mais antigas; desenhos (inclusive na forma de 'papel de parede'); quadros com propaganda; links para outros blogs, para notícias publicadas em outros meios de comunicação e para sites institucionais de interesse; fotos de crianças com alguma deficiência que estão à espera de adoção; prêmios dados ao blog por outros leitores (bloggers). A forma como o autor dispõe esses elementos e a prioridade que é dada a cada um variam de acordo com o gosto e o estilo pessoais e com aquilo que é escolhido para ser compartilhado e comunicado.

Carlos Novas (Novas \& Rose, 2000), em seu trabalho com webforums sobre doença de Huntington, identificou quatro dimensões nas tecnologias do self. A primeira delas diz respeito a uma identidade genético-molecular, construída basicamente com elementos médicos relativos à presença $e$ à transmissão de uma condição específica. Envolve discussões quanto a se submeter ou não a testes preditivos e as possíveis consequências, sendo uma delas o experienciar da condição de indivíduo sob risco genético, que passa a se pensar como um ser genético-molecular.

A segunda dimensão refere-se a um domínio ético que indivíduos assintomáticos ou sob risco têm que confrontar e que abarca decisões tais como ter ou não filhos, ou ainda como e quando revelar a filhos e familiares a possibilidade de terem herdado uma condição genética e de fazer determinados testes preditivos.

A terceira dimensão é concernente ao fato de que tais indivíduos, em decorrência do conhecimento adquirido por meio da vivência e de numerosas fontes, não apenas médicas, e da solicitação (externa e interna) por responsabilidade e autonomia, tornam-se experts leigos, configurando novas formas de relação com o conhecimento especializado e buscando caminhos para a otimização de saúde e bem-estar.

Por fim, a quarta dimensão abarca o que Novas nomeou estratégias de vida, maneiras de se lidar com a vida no presente (Novas \& Rose, 2000), mas tendo em mente um eixo temporal que a liga ao futuro, um futuro marcado por risco em termos genéticos, por meio de objetivos, tarefas ou estágios. 
Nas narrativas sobre SD, é possível observar essas quatro dimensões, ainda que com certas diferenças. A identidade que se configura em indivíduos com SD é calcada em aspectos médico-genéticos, mas em razão de uma situação que já é dada. Ou seja, são os pais, parentes, pessoas próximas que começam a construí-la por ocasião do diagnóstico intraútero ou do nascimento da criança, sendo paulatinamente assimilada pelas pessoas que têm SD. Com exceção dos casos em que existe uma translocação que foi herdada, a grande maioria deve-se a uma irregularidade na divisão celular que aconteceu ao acaso e que é considerada como um 'acidente genético'. Nesses casos, não existem 'indivíduos suscetíveis a desenvolver $\mathrm{SD}^{\prime}$, no mesmo sentido que em outras configurações genéticas, mas pais e mães com determinado nível de risco de terem um filho com essa condição, especialmente em se tratando de mulheres com mais de 35 anos. ${ }^{14}$

A presença da SD numa criança representa uma quebra na vida daqueles que com ela convivem e introduz as dificuldades e preocupações a serem enfrentadas referentes à possibilidade de um futuro autônomo $e$ produtivo (às vezes também reprodutivo) de seu filho, requerendo uma reestruturação do tempo em termos de foco e disponibilidade e uma reavaliação dos planos e prioridades (Morgan \& Thomas, 2009). A vivência do presente torna-se um elemento fundamental no sentido de que não há como imaginar o futuro de alguém com $\mathrm{SD}$, pois as expectativas e os ideais foram lançados por terra com a ruptura do padrão de normalidade aceito socialmente, e também pela dificuldade dessas pessoas em realizar a abstração que carreia a noção de tempo e que dá dimensão ao que é passado e ao que é futuro, alterando a percepção de todos à sua volta.

Pouco a pouco, o que era inexperiência e ignorância no assunto, parcial ou completa, transforma-se em conhecimento, não apenas pela aquisição de novas informações médicas, mas pela vivência, capacitando pais e parentes de pessoas com SD como novas formas de autoridade que podem se aliar a autoridades especializadas já estabelecidas ou confrontá-las.

A vida com a SD também se pauta por metas a serem alcançadas numa linha temporal. Novas estratégias de vida substituem as antigas, assim como novas expectativas substituem as que foram frustradas. 
Definitivamente, a vida foi alterada à luz da $\mathrm{SD}$, e o presente deve ser administrado para que o futuro dessas pessoas possa ser o melhor possível diante de algo que é irreversível.

\section{Significados, o Desenho do Rendilhado}

O discurso nas narrativas veiculadas em livros e blogs mostra-se ambivalente: por um lado, existe a marca daquilo que é inesperado e resulta em diferença no que concerne ao desenvolvimento da criança, às expectativas, ao estigma social, e que se expressa como valorização da multiplicidade inerente a essa diferença. Tal atitude pode ser resumida pela frase "eu sou especial", ${ }^{15}$ um consenso nas histórias. Por outro lado, o discurso é focado na aceitação da diferença por meio da sua normalização, sendo povoado por imagens que traduzem essa ambivalência e ressignificam aquilo que é característico da SD, num tom de exaltação crescente, com profusão de adjetivos, como nas frases "uma cópia extra do cromossomo 21, bênçãos extras de Deus", ${ }^{16}$ "um cromossomo extra, que torna as pessoas extra-adoráveis", ${ }^{17}$ "fofura vem com um cromossomo extra" ${ }^{18}$ Um tom de competição é assumido em muitas narrativas, nas quais a presença do cromossomo extra revela-se como aprimoramento das características vitais da pessoa, valorizando-a: "meu filho tem mais cromossomos do que o seu"; 19 "síndrome de Down ou trissomia do 21 ou T21... até melhor, com um gene de grife!"; 20 "eu sou aprimorada geneticamente!"21

Conjuntos de semas compostos por diversos níveis de significados se repetem uma e outra vez ao longo das narrativas. Eles condensam atitudes e sentidos por meio dos quais as pessoas descrevem suas próprias experiências e as tornam significativas. A presença deles permitiu a própria organização do material pesquisado, desdobrando-os em suas sutilezas e ensejando o desvelar de eixos temáticos comuns. 'Diferente', 'especial', 'anjo', 'príncipe e princesa', 'capacidade' e 'vencedor' são alguns deles, verbalizados na tentativa de se traduzir em atributos a identidade difusa de alguém que traz a marca da alteração genética como elemento principal. Em alguns relatos, tais significados aparecem para serem contraditos, numa tentativa de se romper com estereótipos usados para rotular essas 
pessoas. Porém, nem sempre essa ruptura é lograda, tal é a força desses atributos no ideário sobre o tema.

Genes são vistos popularmente como fenômenos naturais isentos de significados resultantes de interações sociais, isto é, entidades da natureza objetivamente descritas e preexistentes. Entretanto, genes e corpos, assim como outros elementos naturais-tecnológicos, emergem de um processo discursivo (Haraway, 1992).

O mesmo tende a ocorrer com a SD: além do padrão de normalidade, as narrativas sugerem a perspectiva do natural como a mais adequada para compreender a síndrome e as pessoas que a apresentam, desconsiderando que a SD existe não apenas como condição orgânica, biológica, mas também como construção discursiva, resultado da interação entre diversos atores, humanos e não humanos (Haraway, 1992). O natural, aqui, ocupa o lugar daquilo que é inerente à pessoa, e que responde pelo mais básico do seu ser, sua corporalidade e os atributos identitários recebidos como herança, como a cor dos olhos, dos cabelos ou o temperamento, mas é uma herança que, em realidade (salvo nos casos de translocação), resulta de uma abrupta desregulagem, como no texto de João Gilberto Noll (2003). O natural também diz respeito a uma espécie de força determinante ou causa biológica, que define a SD. A pessoa e a condição genética se confundem: a divisão celular diferente da normal e que leva à não disjunção do cromossomo 21 é metonimicamente colocada no lugar da criança que tem SD, desencadeando uma forte reação em defesa da 'adequação' do filho. O cromossomo 21 extra torna-se sinônimo da condição SD e adquire existência e identidade independentes da criança, sendo referido como um dos membros da família.

A ótica do natural tem a intenção de destituir a pessoa que nasce com SD de seu caráter de desviante, ilusoriamente eliminando as acepções negativas ou discriminatórias a ela associadas. Subjacente a essa perspectiva, e aqui retoma-se a proposta de Ian Hacking (2000), encontra-se o entendimento da SD como um 'tipo' indiferente, e por isso incapaz de alterar o seu objeto de classificação, uma condição de base genética, determinada pelo excesso de carga gênica de um terceiro cromossomo no par 
21. Porém, apesar da sua base genética, o termo também se refere a um 'tipo' interativo, uma vez que a classificação interage com as pessoas que com ela nascem, alterando o modo como elas se percebem, agem e se ajustam a tal classificação.

Então, o que é considerado como sendo perspectiva do natural na verdade acresce mais um elemento na composição da ideia sobre as pessoas com SD. Elas tornam-se ícones no sentido de reprodução da natureza cultuada como sagrada; pessoas não corrompidas pela mediocridade humana, vivendo em harmonia com os preceitos da natureza. A conexão com a natureza dissimula a diferença e devolve à pessoa a imagem do 'mesmo', ainda que deslocado ou distorcido, como nos fenômenos ópticos de reflexão e refração (Haraway, 1992). Fornece, ainda, uma resposta que amaina as angústias decorrentes da falta de controle no que se refere ao risco e à prevenção, especialmente na trissomia livre, grande maioria dos casos.

A 'jornada' está presente em todas as narrativas, ora num sentido claramente metafórico, ora num discurso naturalizado que sinaliza o seu esvaziamento e a sua instauração como mito. É um tema identificado também em pesquisa realizada por Rayna Rapp (2000) com grupos de apoio para pais de crianças com SD.

O tema da jornada ou peregrinação é encontrado em vários sistemas mitológicos de diferentes culturas em dois aspectos: o primeiro deles é a jornada empreendida pelo herói em direção ao desconhecido para o cumprimento de tarefas necessárias ao fortalecimento de sua personalidade. No percurso, ele descobre seus próprios recursos ou tem acesso a poderes superiores que o ajudam. O retorno do herói revigorado pelo conhecimento adquirido (inclusive sobre si mesmo) é uma etapa fundamental e que completa o ciclo. O segundo aspecto é a jornada com caráter de libertação, de renúncia e expiação, com um fim último de transcendência, com a orientação de um guia espiritual (Henderson, 1996).

Nas narrativas, a jornada evoca a perda de rumo, mas diferentemente da jornada do herói, não há volta possível. O rumo foi perdido para sempre, e outro caminho tem de ser encontrado. É uma aventura em direção ao desconhecido, a algo que é inatingível, dando dimensão aos percalços e 
desafios enfrentados, e que pode ser comparada à metáfora da jornada espacial tão usada na genética, na qual a conquista do espaço infinito é possível graças aos avanços da tecnologia humana.

São os pais que, obrigados a deixar a segurança do conhecido, partem nessa aventura em busca do fortalecimento de si mesmos. E nesse percurso reconhecem na figura do próprio filho com SD o papel do guia ou professor iluminado, especial, diferente, aquele que sabe o verdadeiro caminho, persistente, determinado, genuíno, não corruptível, em harmonia consigo e com a natureza, capaz de ensinar a todos na família e no mundo, por ser um presente de Deus, uma espécie de mediador espiritual. Cada sinal revelador da SD ganha uma dimensão metafórica que transforma o olhar sobre essas pessoas, como as manchas de Brushfield, por exemplo, aquelas pequenas nódoas brancas e brilhantes visíveis nos olhos de indivíduos com SD, que se tornam "estrelas" (Klein \& Schive, 2001: 22).

Esse é o modo como as famílias conseguem lidar com o vértice do impensável, com o choque, o desespero, o medo diante do desconhecido e do 'defeituoso' ou 'partido'. ${ }^{22}$ As tarefas fazem parte da jornada, relacionadas à sobrevivência deles, pais, diante da morte do filho desejado e esperado, como forma de dar sentido ao vazio interno. A possibilidade de interromper a gestação está sempre presente, de forma mais ou menos clara, oferecida pelos médicos (em países onde isso é possível) ou pensada pelos pais. A ideia de que é filho deles e que é natural a sua vinda, e consequentemente a sua aceitação (não se pode esquecer que a SD já está presente de forma inexorável), surge como justificativa para não fazê-lo. Os olhos amendoados são a chave, a descoberta de algo diferente - "por favor, feche os olhos", diz a mãe na sala de parto (Klein \& Schive, 2001: 137) - e também a explícita doçura em cada um deles, afinal, não são os olhos o espelho da alma? Ou, como diz Fernando Pessoa (2008), do movimento da alma?

O sistema mitológico que serve de base para a compreensão da presença da SD é o judaico-cristão, com suas narrativas de salvação e seu Cristo que vem para libertar os humanos do pecado e ensinar aquilo que foi perdido no viver mesquinho; o deus triste e comovido que consola os 
que sofrem, a que Ricardo Reis, heterônimo de Fernando Pessoa (1994), alude como aquele que faltava no panteão dos antigos deuses. Em termos junguianos (Jung, 2000), a pessoa com SD sugere uma manifestação do arquétipo $^{23}$ da criança divina, evidenciado no paradoxo inerente ao herói de ser a um só tempo frágil e indefesa, mas também possuidora de forças que ultrapassam a medida humana e adentram o domínio do divino. A família sente-se tocada pela SD como por um milagre, abençoada pela presença de um cromossomo a mais, o que de certa forma dilui a responsabilidade por uma decisão quanto a manter a gestação. O significado de mediador ou guia espiritual em harmonia consigo mesmo e com a natureza, atribuído às pessoas com $\mathrm{SD}$, faz parte dessa mitologia e remete o leitor à Cidade de Deus de Santo Agostinho.

Civitate Dei foi escrito por Santo Agostinho entre os anos 413 e 427 (Saint Augustine, 2003). Considerado um clássico, o livro ainda hoje é constantemente reeditado pela sua importância histórica e por ser uma fonte do ideário cristão. Nele, o autor escreve sobre uma cidade cujos laços entre as pessoas são de amor, estando unidas por um senso comum de bondade e justiça. Constantemente citada, outra cidade é contraposta à cidade celeste: a cidade terrena. Ambas estão entrelaçadas em sua existência, e os seres humanos e angélicos que as habitam não teriam consciência de a qual delas pertenceriam. Sem a queda dos anjos e de Adão e Eva, as duas cidades não teriam razão de ser.

As raízes maniqueístas de Santo Agostinho estão aqui presentes quando ele descreve seus habitantes em dois grupos: aqueles que optaram por viver de acordo com os princípios da carne e os que optaram pelos princípios do espírito. Entretanto, ele afirma, o pecado se apresenta na alma e não no corpo; suas evidências carnais são apenas consequência de sua instalação na alma. Deus a tudo criou em perfeita harmonia em sua natureza, e uma grande importância é dada por Santo Agostinho ao fato de os homens serem criaturas racionais, cuja característica principal é o livre-arbítrio. Seria pelo livre-arbítrio que cada homem escolheria ser habitante da cidade terrena ou da Cidade de Deus. 
Os significados explicitados nas narrativas ecoam o texto de Santo Agostinho. A presença do retardo mental impele ao movimento de substituição da inteligência e de sua medida, a razão, como bens supremos de uma pessoa, por qualidades que os homens parecem ter esquecido. Assim, as pessoas que têm SD são apresentadas como em estado de pureza, libertas das limitações que poderiam levá-las a fazer escolhas em desacordo com os princípios do espírito e da luz. O corpo 'imperfeito' não as impede de viver os laços de amor prevalentes entre os habitantes da Cidade de Deus. Seres humanos ou angélicos, considerando-se a metáfora do 'anjo' prevalente nos textos, as pessoas com SD são elevadas ao que o homem comum não é: a capacidade de amor incondicional, a vivência do presente, o ritmo de vida mais lento de acordo com as possibilidades de cada um são características que o homem contemporâneo parece ter perdido e não consegue reencontrar. Com a presença dessa criança, isso seria novamente possível. Todo lar deveria ter uma criança com SD; sua existência faz diferença no mundo, é dito (Soper, 2007).

A 'imperfeição' genética na forma de SD apresenta-se como algo a ser prezado como um raro tesouro, como na analogia com as lagostas azuis (que lembram as tulipas azuis, ${ }^{24}$ já mencionadas), descrita num dos blogs. ${ }^{25}$ Resultado de uma anomalia genética, as lagostas azuis, cuja ocorrência é de uma em dois milhões, são celebradas pelos pescadores e consideradas especiais justamente por sua constituição 'imperfeita', diferente do padrão.

De forma complementar à análise dos livros e blogs, observou-se que esses mesmos significados estão presentes em algumas produções cinematográficas que trazem personagens com SD. O filme norte-americano A Sétima Profecia (The Seventh Sign), de 1988, dirigido por Carl Schultz, explicita a associação entre a SD e a mitologia judaico-cristã. Classificado como drama, mas com pinceladas de suspense, o enredo aborda o evento do Apocalipse, conforme descrito no Livro das Revelações. Um a um, os sinais que antecedem o fim do mundo se manifestam, e uma mulher, prestes a dar à luz, vê-se envolvida na terrível cadeia de eventos. Um desses sinais é a morte do mártir, representado por um rapaz com SD que 
assassinou os pais, irmãos entre si, para puni-los por incesto, seguindo os preceitos de Deus (seria a SD já um castigo divino?). Assassino por livrearbítrio destinado à pena de morte, ser humano considerado incapaz e não responsável por seus atos por ter $\mathrm{SD}$, ou ser humano puro que age de acordo com a lei de Deus são as perguntas lançadas pelo filme.

O sentido da criança com SD como reparação na vida de pais e familiares é marcante, reparação por uma vida vazia, egoísta, autocentrada. A quebra na continuidade entre o passado e o presente é transmutada em justificativa para a sua vinda. Por meio dessas crianças, os habitantes da cidade terrena podem se aproximar da cidade celeste, a Cidade de Deus. Após a perda da perfeição inicial idealizada para o filho, outra perfeição é alcançada, descrita como mais pura, mais desejada, mais 'perfeita'. As conquistas são alcançadas mais tarde, mas quando ocorrem são perfeitas. Perfeição é, então, definida nas narrativas como aquilo que esses filhos são capazes de trazer aos outros e que os eleva como humanos. Esse sentido é retratado no filme inglês AfterLife, ${ }^{26}$ de 2005, dirigido por Alison Peebles, no qual um jovem e ambicioso jornalista, que prepara uma reportagem sobre um médico suspeito de assistir o suicídio de pacientes terminais, ao saber que sua mãe está com câncer em fase terminal, vê-se obrigado a cuidar de sua irmã que tem SD. A situação de doença da mãe e a convivência com a irmã leva-o a reavaliar sua vida, suas responsabilidades e sua incapacidade em se aprofundar nas relações interpessoais.

Seguindo outra linha de abordagem, o episódio 22 da terceira temporada do seriado Lei e Ordem: unidade de vítimas especiais, "Competência" (Law \& Order: special victims unit, "Competence"), de 2002, produzido pela rede NBC, de certa forma apresenta outra faceta dessas asserções. Nele, uma adolescente com SD aparece grávida, e a alegação de abuso sexual, baseada na falta de informações da adolescente sobre sexo, conflita com o seu desejo de ter o bebê, pois a incompetência no primeiro caso significaria também uma incompetência no segundo. O filme traz às telas a discussão sobre a capacidade das pessoas com SD de fazer escolhas autônomas sobre suas vidas - no caso, ser capaz de recusar um assédio sexual e criar um filho. 
Mais recentemente, o personagem principal do filme de Pedro Almodóvar Abraços Partidos (Los Abrazos Rotos), de 2009, um escritor que ficou cego após um acidente, quer escrever uma narrativa de superação e diz-se inspirado pela história do escritor e diretor Arthur Miller, o qual teve um filho com SD na década de 1960 e o colocou numa instituição ainda recém-nascido, aparentemente eliminando-o de sua vida pública e privada. Segundo publicado no jornal inglês Telegraph, versão on-line, em 18 de abril de 2009, Almodóvar desenvolveu o argumento do filme com base nesse fato, com a intenção de discutir os efeitos perversos nas relações entre pais e filhos. No filme, a alusão feita ao reencontro público entre pai e filho exalta a falta de rancor ou a presença de uma bondade inata que permitiu ao filho abraçá-lo afetuosamente apesar da rejeição.

Em certo sentido, a presença do retardo mental na SD e, de modo geral, de deficiências em outras condições revela uma forma de infantilização que, segundo Rapp (2000), remonta a uma vertente evolucionária característica do pensamento intelectual ocidental do século XIX e que faz referência a determinados grupos culturais como representantes de uma etapa anterior do desenvolvimento humano. De forma equivalente, pessoas que apresentam alguma deficiência são homogeneamente 'infantilizadas', sendo vistas como social e psicologicamente dependentes, incapazes de compatibilizar os conflitos relacionados ao crescimento e amadurecimento.

Pais de pessoas com SD tornam-se militantes no sentido de tentar mudar tal concepção no viver diário, mas frequentemente são capturados nos meandros desse pensamento, lançando mão de discursos ambivalentes para acomodar ambas as perspectivas. Ainda que reconheçam as conquistas alcançadas, surpreendem-se assombrados por fantasmas do futuro que turvam a claridade do presente. 
1 Em tradução livre: "a vida não é a que se viveu, mas a que se recorda e como se recorda para contá-la".

2 As ultrassonografias tri e quadridimensionais são usadas não apenas para investigar suspeitas relativas ao desenvolvimento fetal, mas também para fins não diagnósticos, como a produção de 'fotografias' e a possibilidade de se estreitar o vínculo com o bebê, por exemplo. Em países como o Reino Unido, essas técnicas estão ligadas aos debates sobre aborto, em especial sobre o tempo limite para a sua realização (Palmer, 2009).

3 Sem título em português. Em tradução livre: Fios Comuns: celebrando a vida com síndrome de Down.

4 Sem título em português. Em tradução livre: Presentes: mães refletem sobre como crianças com síndrome de Down enriquecem suas vidas.

5 Sem título em português. Em tradução livre: Você Sonhará Novos Sonhos: histórias pessoais inspiradoras de autoria de pais de crianças com deficiências.

6 Sem título em português. A primeira parte do título faz um jogo de palavras com a expressão down-and-out, que significa fracassado, destituído, deixando claro, portanto, que ter SD não significa ser fracassado. A segunda parte complementa: uma jornada do luto ao contentamento.

7 Sem título em português. Em tradução livre: Mapa de Percurso para a Holanda: como encontrei meu caminho durante os dois primeiros anos do meu filho com síndrome de Down.

8 Sem título em português. Em tradução livre: Onde Está Chimpy? (um macaco de pelúcia).

9 Sem título em português. Em tradução livre: Nós Pintaremos o Polvo de Vermelho.

10 Sem título em português. Em tradução livre: Nosso Irmão tem Síndrome de Down.

11 Sem título em português. Em tradução livre: Eu Posso, Você Pode?

12 Sem título em português. Em tradução livre: Minha Amiga Tem Síndrome de Down.

13 Essa atitude também está presente no blog de uma mãe que entregou o filho com SD para adoção e que se considera ligada à comunidade $\mathrm{SD}$, apesar de achar que não tem esse direito. Disponível em: <http://havefallendown.blogspot.com>.

14 Aproximadamente 1/1.400 entre 20-24 anos e 1/100 aos 40 anos (Nussbaum, McInnes \& Willard, 2002).

15 Frase extraída do blog Where There's a Will. O nome do blog faz um jogo de palavras entre o nome da criança (Will) e o conhecido refrão "where there's a will, there's a way", cujo significado alude à capacidade de determinação que faz encontrar um caminho. Disponível em: <http://willswebplace.blogspot.com>. 
16 Frase extraída do blog Extras. Disponível em: <http://gotsnow.org > . No original: An Extra Copy of the 21st Chromosome; Extra Blessings from God.

17 Frase extraída do blog <http://hiddentreasuresthet21journey.blogspot.com > . No original: An Extra Chromosome that Makes People Extra Lovable!

18 Frase extraída do blog <http://megansgot47.blogspot.com>. No original: Cuteness Comes with an Extra Chromosome.

19 Frase extraída do blog <http://churchillchronicle.blogspot.com>. No original: My Kid Has More Chromosomes than Yours.

20 Frase extraída do blog <http://hapagirlhapafamily.blogspot.com>. No original: ...DOWN SYNDROME or Trisomy 21 or T21... Even Better, with a Designer Gene!

21 Frase extraída do blog < http://zoromski.blogspot.com>. No original: I'm Genetically Enhanced!

22 Em muitas narrativas, as crianças com SD ou alguma outra deficiência são referidas em discurso como crianças partidas. No original: Broken Children.

23 Arquétipo, segundo Carl Gustav Jung (2000: 17), "representa essencialmente um conteúdo inconsciente, o qual se modifica através de sua conscientização e percepção, assumindo matizes que variam de acordo com a consciência individual na qual se manifesta".

24 Não se pode esquecer que na língua inglesa a cor azul está associada a sentimentos de tristeza e melancolia, os quais também estão presentes nas narrativas, relacionados à morte de um ideal de filho(a).

25 Disponível em: <http://mybluelobster.blogspot.com>.

26 Sem título em português. Em tradução livre: Após a Vida. 


\section{TERCEIRO EPISÓdio: 'EU SOU EU E MINHA CIRCUNSTÂNCIA' '}

Na era genômica, o corpo, considerado como um sistema, um conjunto de órgãos, tecidos, fluxos, funções, tornado foco do olhar clínico a partir do século XIX, ainda é apresentado e pensado como 'visível'. Entretanto, passa a coexistir com o corpo biomédico contemporâneo, do qual difere em escala: para além de uma interiorização do olhar do tecido para a molécula com base em instrumentos mais precisos, o que ocorre é uma reorganização desse olhar. Não se trata apenas de visualizar, mas de isolar os elementos, manipular, amplificar e reproduzir, num processo de abertura sem precedentes desse corpo à tecnologia, que requer novas formas de entendimento, regulação, padronização e ética.

É essa abertura que torna possível não apenas pensar em modificar condições de doença ou de incremento à saúde por meio de elementos externos, como dietas ou exercícios, mas trabalhar com a plasticidade humana, reconfigurando os próprios processos biológicos vitais inseridos numa 'normalidade', com o intuito de aprimorar sua dinâmica e seus resultados (Rose, 2007).

A redefinição das fronteiras entre o saudável e o doente, com o surgimento de uma terceira possibilidade, o indivíduo sob risco genético, ressalta a suscetibilidade como um importante elemento. Riscos potenciais futuros são trazidos para o presente, gerando com isso a necessidade de intervenção (Novas \& Rose, 2000). 
Os indivíduos nos quais se intervêm são encarados como consumidores livres e capazes de escoelha porque mais informados, segundo uma lógica de mercado condizente com as democracias liberais avançadas (Miller \& Rose, 2008b). É enfatizada a necessidade de um letramento genético por parte da população, que permita o entendimento das condições individuaisfamiliares e das narrativas possíveis que são vislumbradas para cada grupo específico. Assim, a capacidade da Internet de difundir informação, ainda que certos conteúdos sejam questionáveis quanto a sua qualidade e acurácia (Castiel \& Vasconcellos-Silva, 2006), torna-se um elemento fundamental, deslocando eixos hierárquicos e apresentando alternativas no processo de produção de verdades.

A condição de pessoa está cada vez mais relacionada ao discurso genético, o qual inclui imagens que são difundidas e assimiladas globalmente através de trocas simbólicas, realizadas fora dos limites das referências espaciais, por meio de material escrito, comunicação oral ou outras formas de manifestação humana. De certo modo, essas imagens transformam-se em mercadorias, cuja ampla circulação marca uma homogeneização da população em termos do seu consumo (Franklin, Lury \& Stacey, 2000).

Observa-se a crescente presença da genética no cotidiano das pessoas, trazendo à tona aspectos relacionados a parentesco, risco e identidade genéticos. Doenças herdadas geneticamente, programas de rastreamento genético, células-tronco, terapia gênica, correlações entre genes específicos e comportamentos estão presentes em revistas leigas, programas de televisão, manchetes de jornais e redes virtuais como a Internet.

A difusão cada vez maior de argumentos genéticos sobre aspectos de saúde, doença, hábitos e comportamentos modifica o olhar sobre os corpos - o corpo anatomopatológico, o corpo transparente revelado pelas tecnologias de imagem (Van Dijck, 2005), o corpo genômico -, possibilitando novos pontos de vista a partir dos quais se constroem discursos sobre o mundo, não apenas no campo da biologia. Para além das células, cuja permeabilidade aponta para a possibilidade sempre presente do risco, estão os genes com suas complexas interações, envolvendo mais incertezas 
do que certezas acerca das informações sobre cada pessoa e por isso também sinalizando riscos nas biografias corporificadas.

O processo de desnaturalização de elementos extraídos do contexto biológico, tais como o gene, e a renaturalização deles em outros contextos contribuem para a criação de novos mitos no sentido barthesiano. A ênfase dada à visualização desses elementos cria a ilusão de uma realidade cada vez mais 'real' e, portanto, mais 'verdadeira', mas que transforma o real em imagem e a imagem em real (Joyce, 2005).

Neste terceiro episódio, discute-se como o tema SD (nos aspectos de conhecimento especializado, valores, crenças e opiniões) é tratado e veiculado nas narrativas verbais e não verbais que compõem as reportagens da revista Veja e do jornal O Globo. Os significados nelas presentes revelam como esses aspectos vêm sendo assimilados, transformados e difundidos socialmente, assim como sua contribuição para demarcar os limites de identidade de pessoas com SD e forjar escolhas a ela relacionadas.

A terceira entrada de voz desenvolve o tema variando o tom e o ritmo, espelhando-o, modulando-o, resumindo-o ou mesmo expandindo-o; de certa forma, reúne fragmentos do tema espalhados pela música.

\section{AprimORAR O NORMAL: A PLASTICIDADE DOS CORPOS}

Novas formas de entendimento da corporalidade são consideradas nas relações que os indivíduos estabelecem consigo mesmos, no seu reconhecimento como sujeitos, e também com as autoridades biomédicas, sejam elas especialistas no que se pode considerar como existência somática, sejam em novas formas de atividade pastoral, com funções de aconselhamento, cuidado e suporte. Tais atividades não pretendem direcionar as pessoas em suas escolhas, porque se supõem calcadas em autonomia de decisão, sobretudo nas sociedades neoliberais.

O olhar clínico, como ferramenta diagnóstica, deixou de ser monopólio médico e passou a ser regulado também por circunstâncias externas, tais como os procedimentos estandardizados da medicina baseada em evidências, 
ou interesses econômicos relacionados a seguros-saúde ou à indústria farmacêutica.

O público em geral está cada vez mais atento a formas de aperfeiçoar o corpo tangível, visível, a um só tempo fragmentado e unificado que age e se comporta por meio de diferentes tecnologias relacionadas a cura de doenças, dietética, exercícios, cosmética e intervenções invasivas, como a cirurgia, a fim de melhorar o seu funcionamento (como, por exemplo, as numerosas próteses, hoje corriqueiras) ou a sua aparência (cirurgias reconstrutoras ou cosméticas). E para tanto, busca informação em manuais de boa forma, reportagens em revistas, suplementos em jornais, programas de televisão, inclusive em tabloides sobre celebridades, em que novas receitas de cuidados ou novas formas de escrutar o corpo são delineadas, comentadas e estimuladas.

Apesar de a identidade de um indivíduo ser constituída de forma plural, dependente das práticas em que se insere, e a identidade genética ser apenas um dos seus aspectos em constante interação com outros elementos, tais como nacionalidade, cultura, sexualidade e religião, entre outros, fala-se cada vez mais de quem se é com base em uma existência somática alicerçada no discurso biomédico e, mais especificamente, genômico. A atuação no corpo justifica-se como melhoria física e também psicológica. É por meio dessa existência corpórea que se adquirem experiências de vida, que se estabelecem novos jogos de verdade, na acepção foucaultiana (Foucault, 2006), nas relações das pessoas com elas mesmas, e que se busca melhorar a si mesmo. Emoções, sentimentos, desejos, humores tornam-se acessíveis graças aos fenômenos moleculares alvos de visualização.

Além das artes performáticas e visuais que expuseram o corpo em suas várias dimensões por meio de diferentes leituras, ele passou a ser exibido na mídia, em programas televisivos, por exemplo, em que a intervenção e a manipulação por tecnologias biomédicas são o foco, evidenciando o apelo e a fascinação que o corpo, com suas representações, significados e funcionamento, exerce sobre o público. Nesse sentido, Hacking $(2005,2007)$ sugere que o corpo, longe de ser naturalmente dado, está 
sendo reafirmado como aquele concebido por Descartes, um corpo mecânico, diferente da mente, com partes intercambiáveis e passível de ser modificado; um corpo com o qual cada um se relaciona como sendo um 'outro'. A desestabilização que o desenho genômico traz aos corpos em sua definição como natural e estável provoca mudanças também nas instituições que se apoiam nesse conceito de corpo. Novas formas de construção do 'eu' são solicitadas, com novas práticas e novos caminhos de expressão corporal.

O processo de visualização dos corpos provocado pelo surgimento de tecnologias de imageamento, tais como os raios X em 1895 e, posteriormente, a tomografia computadorizada (TC), a ressonância magnética (MRI) e a tomografia por emissão de pósitrons (PET), que expuseram os corpos em privacidade e profundidade, traduziu-se metaforicamente como uma forma de autoconhecimento (Joyce, 2005). Hoje, a possibilidade cada vez maior de acesso aos corpos aponta para um movimento que deixa de ser predominantemente vertical, expandindo-se horizontalmente - isto é, o gene que antes aparecia em discurso como algo relacionado à determinação e espacialmente escondido em profundidade, verdade a ser revelada, hoje é considerado pelo discurso genômico como sendo da ordem de superfícies, conexões, probabilidades e novas formas de conhecimento de si. O foco é deslocado do gene para os seus processos de regulação, expressão e transcrição e, em última instância, para os processos celulares dos quais participa e a relação entre seus produtos (Rose, 2007).

O corpo tangível convive com o corpo molecular que é objeto da biomedicina contemporânea, cujo olhar oferece novas formas de visualização da 'vida em si' e do aparato tecnológico que as torna possíveis, e que diz respeito mais a complexas redes não hierarquizadas e suas conexões (Franklin, 2000). O corpo fragmentado pelo olhar anatomopatológico e pelas tecnologias de visualização ganha nova leitura diante do olhar molecular, sendo reformulado fora da moldura imposta pela polaridade fragmentação-unificação.

O corpo molecular ganhou espaço na mídia e foi incorporado ao cotidiano das pessoas: células-tronco, seleção de embriões, animais 
transgênicos, novas tecnologias diagnósticas são alguns dos tópicos encontrados em textos e imagens nas reportagens analisadas.

Da mesma forma, cada vez mais aspectos da vida são expressos e publicamente discutidos em termos de probabilidades e estratégias de controle. Cabe aos profissionais responsáveis por atividades pastorais a mediação entre os pacientes e as informações expressas por meio de cálculos probabilísticos, 'futuro-orientadas', preditivas e baseadas em evidências, indicando suscetibilidade para doenças futuras, ainda quando são incapazes de sinalizar mais do que promessas, especialmente com relação a traços comportamentais.

Entretanto, a presença crescente desses temas na mídia não significa que o assunto seja sempre tratado com profundidade ou mesmo propriedade. Em muitas situações, ele é referido simples e uniformemente como 'a genética', ou ainda em substituição ao que é considerado como 'natureza' ou 'natural', isto é, aquilo que é dado a cada um ao nascer. Em outras, a mensagem veiculada reafirma o papel da ciência em reconfigurar o que seria da esfera do biológico, na medida em que expande os limites tidos como naturais, conformando, portanto, uma segunda natureza, com inúmeras alusões a fantasias sobre a manipulação do humano. Em ambos os casos, a sugestão implícita deixada em aberto é a definição do ser humano como indivíduo somático e, como tal, a possibilidade de sua manipulação tecnológica pelo próprio homem, resultando em destinos genéticos que são naturalizados.

Nas reportagens, os argumentos relacionados à possibilidade de se forjarem os corpos tendem a uma possível aplicação direta aos seres humanos dos últimos achados experimentais, simplificando o que é complexo em suas múltiplas interações e, muitas vezes, enfatizando resultados específicos em detrimento de outros aspectos importantes como os metodológicos (Castiel, 1999; Brechman, Lee \& Cappella, 2009). A passagem do âmbito daquilo que é substância corporal para o âmbito das noções abstratas, veiculadas pelas pesquisas ou por informações probabilísticas sobre riscos, dá-se pela capacidade do gene de aludir a domínios diversos, o mundo experiencial, o ficcional e o especulativo. 
A vida, tratada no nível molecular, deixa de estar limitada pelos extremos de normatividade e passa a lidar com o aspecto da suscetibilidade e da reconfiguração no presente dos processos vitais relacionados a uma eventual doença futura cuja incerteza descortina uma ampla gama de possibilidades apenas vislumbradas. Nas narrativas analisadas, as especulações no presente encontram respaldo nas referências feitas a um futuro não muito distante em que as descobertas serão possíveis. As frases assim construídas enfraquecem o peso da incerteza e transformam especulações em 'fatos', cuja aparência de 'solidez' contribui para a obliteração de elementos controversos ou passíveis de contestação (Fennell, 2009).

A modificação daquilo que é da esfera do biológico está presente na pauta do material editado para o público em geral, não mais como apelo médico, apesar de calcado em bases científicas, mas como produto a ser escolhido, adaptado a cada indivíduo e consumido além do nível orgânico.

Os indivíduos são instados a decidir em aspectos ligados à saúde e à relação com seus corpos; entretanto, alguns autores argumentam que a noção de escolha autônoma baseada exclusivamente em informações objetivas configura-se mais como retórica do que como realidade, mas ainda assim faz parte do ideário genético contemporâneo (Felt et al., 2009; Kerr, 2004). As relações são dinâmicas, e os limites entre direcionamento, coerção e consentimento são tênues, especialmente quando envolvem a responsabilidade (obrigação?) por comunicar o risco a outros membros da família potencialmente afetados.

No título deste episódio, faz-se uma referência à conhecida frase do filósofo espanhol José Ortega y Gasset (2007). Para o autor, 'circunstância' é tudo aquilo que rodeia o homem, a realidade em seu imediatismo sem julgamentos, ao mesmo tempo externa e interna. ${ }^{2}$ Para que possa dispor de sua capacidade ao máximo, é necessário que o homem tome consciência de sua(s) circunstância(s).

A frase de Ortega y Gasset (2007) é aqui revisitada como uma analogia. Se para o autor a 'circunstância' é indissociável do indivíduo em sua forma de se orientar no mundo, aqui ela é acrescida da dimensão genômica, da mesma forma interna mas entrelaçada à realidade exterior, familiar, 
cultural. Tal releitura está relacionada à presença cada vez maior dessa dimensão na esfera pessoal e na percepção do 'eu' como indivíduo somático, cuja convivência com cálculos sobre risco torna-se rotineira, produzindo um profundo rearranjo das relações da pessoa consigo mesma e com o mundo.

Ao falar de genes, o indivíduo utiliza uma referência que é inegavelmente somática, mesmo quando desfocada por cálculos probabilísticos; ao mesmo tempo, refere-se a algo que é como uma força motriz dessas características corpóreas, determinante de um futuro, ou um "ator interior", nas palavras de Barbara Duden e Silja Samerski (2007: 172), mas que, apesar de interno, revela-se destacado daquele que fala. E acima de tudo, incorpora essa dimensão à sua visão de mundo, às suas expectativas de realização e de futuro. Herança transmitida que alude a um passado familiar e a um presente somático, os 'genes' (ou a dimensão genômica) compõem a 'circunstância' e, como em Ortega y Gasset (2007), são um dos elementos definidores da identidade individual e com o qual cada um deve aprender a se relacionar, no sentido de assumir responsabilidades e fazer escolhas no presente tendo em vista um (projeto) futuro.

\section{As Reportagens}

Além do texto, a imagem presente numa reportagem é em si uma mensagem autônoma formada por três elementos: uma fonte de emissão, que abarca os responsáveis por fazê-la, escolhê-la entre outras imagens, editá-la e comentá-la (título, legenda); uma fonte de recepção, que é o leitor; e um canal de transmissão, que é o próprio meio (jornal ou revista); ou melhor dizendo, essa imagem é composta por todas as mensagens que a acompanham (texto, título, diagramação e até mesmo o nome do meio de comunicação, uma vez que este orienta a leitura da mensagem). Imagem e texto estão em relação constante, apesar de serem diferentes entre si (Barthes, 1977).

É certo que a imagem fotográfica não é a realidade, mas apresentase como seu análogo perfeito, sendo essa sua característica primordial que a leva a ser entendida como mensagem sem nenhum código. Contudo, de acordo com Barthes (1977), entende-se que esse tipo de imagem, conside- 
rada imitativa, contém na realidade dois tipos de mensagem: uma denotativa (aquilo que a faz análoga à realidade) e outra conotativa (que expressa valores da sociedade sobre tal aspecto da realidade).

Tende-se a considerar que as imagens e os esquemas acompanham os textos com o intuito de facilitar o seu entendimento e, principalmente, a sua visualização. Entretanto, nas reportagens, em especial as que se pretendem mais especializadas, são os textos (título, corpo do artigo e legendas) que acompanham as imagens para conotá-las ou refiná-las, e o que ocorre não é mais uma redução (do texto para a imagem), mas uma amplificação, na qual as imagens são consideradas como fundamentalmente denotativas porque naturalizadas. As legendas tendem a ser incorporadas na denotação da imagem em razão de sua proximidade espacial. Em contrapartida, o título (ou manchete) e o corpo do texto têm um efeito mais conotativo, o primeiro por ser enfático e provocar uma quebra; o segundo, pela distância que mantém em relação à imagem. Em muitos casos, o texto amplifica as conotações já presentes na imagem, ou projeta significados, dando a entender que tais significados surgiram na imagem (Barthes, 1977). ${ }^{3}$ Quanto mais tecnocientífico/literal se propõe o texto, mais os significados construídos aparecem mascarados, tanto no texto quanto na imagem, na forma de um significado tido como 'natural', como forma de legitimação de verdade.

Na revista, as reportagens são compostas por um título (manchete) claramente figurativo e imbuído de juízo de valor, que tem como função o apelo à leitura, e por um subtítulo que pretende ser mais 'científico' (literal) e transmitir objetividade, neutralidade e seriedade. ${ }^{4}$ Em algumas pequenas notas, traduções de pesquisas recentes, um único título 'científico' as introduz. No jornal, título e subtítulo (quando presente) tendem a ser menos valorativos, apesar de manterem a relação citada, o primeiro mais figurativo que o segundo, e a intenção de transmitir um conteúdo literal prevalece (apesar da presença de metáforas convencionais), principalmente quando a reportagem está relacionada aos avanços na área da genômica. ${ }^{5}$ Tais arranjos cumprem o papel de definir a moldura dos códigos sociais dentro da qual o texto deve ser compreendido. 
A forma como o discurso é construído tem como uma das funções manter uma estabilidade que se vê questionada pela novidade das notícias. Essa estabilidade manifesta-se no uso recorrente do tom de acordo com o tipo de mídia impressa, como jornais 'de primeira linha' como O Globo, revistas como Veja ou tabloides (Bignell, 2002), por exemplo. A escolha das imagens refere-se não apenas ao texto ao qual elas vêm associadas, mas à seção do jornal ou revista escolhida para veicular a notícia, o que no caso das fontes desta investigação varia significativamente.

A metáfora do teatro proposta por Van Dijck (1998), na qual a circularidade predomina sobre um modelo linear de difusão do conhecimento científico, é importante em se tratando de jornalismo científico que faz a mediação entre o círculo especializado e o público em geral.

Para que possam transitar em diferentes âmbitos, as palavras que designam conceitos científicos necessitam de certa flexibilidade para serem compreendidas, o que resulta no uso de significados diferentes, muitas vezes imprecisos, dependendo da situação em que são empregadas. Os fenômenos se modificam, requerendo novos conceitos, novas formas de pensar e novo vocabulário para melhor expressá-los; porém, o conjunto de palavras que os designam nem sempre acompanha as mudanças, como é o caso do gene, e adquire na imaginação do público uma cristalizada qualidade mítica que pode levar a assunções errôneas.

As metáforas são abundantes no discurso científico, decorrentes do esforço de entender e dar sentido a certos fenômenos, originando outras mais, relacionadas entre si. Uma metáfora envolve dois elementos: o tópico, que é o sujeito literal ou primário, e que é expresso de forma figurativa pelo sujeito secundário, o veículo. O pensamento metafórico se estabelece por meio de uma comparação entre dois fenômenos (ou termos) a princípio não relacionados entre si, que passam a compartilhar atributos, tornando-se semelhantes. Quanto maior a diferença literal entre as categorias às quais o tópico e o veículo pertencem, mais metafórica será a comparação (Knudsen, 2005).

Frequentemente, metáforas científicas começam como interpretações hipotéticas e gradativamente, ao serem discutidas e analisadas, vão 
se transformando em conceitos cuja origem apenas remonta a uma metáfora. Contudo, nesse processo, parte da fluidez é perdida, e as metáforas podem vir a perder capacidade de abertura, cristalizando-se. Metáforas científicas inovadoras tendem a uma expansão conceitual; tornam-se metáforas-raiz, desdobrando-se numa rede de expressões metafóricas secundárias. Quando uma metáfora pouco usual é expressa, existe uma tendência por parte do autor a destacá-la de algum modo, levando o leitor a perceber que se trata de uma metáfora. No entanto, metáforas convencionais já foram incorporadas ao vocabulário científico, sendo desnecessário tal destaque (Knudsen, 2005).

Em artigos de jornalismo científico, certas metáforas-raiz já tornadas convencionais são transmitidas como novas, entre aspas, apoiadas por metáforas secundárias estruturantes, imbuídas de um caráter que não é mais o da novidade, mas pedagógico, visando ao letramento do público em geral (Knudsen, 2005). ${ }^{6}$ Nas imagens, metáforas visuais cumprem o papel de transformar ideias teóricas em significados concretos (Van Dijck, 2006).

Barthes (1977) destaca seis tipos de procedimentos que servem ao propósito de conotar a imagem, isto é, dotá-la de um segundo significado, e que podem ou não estar presentes. Os três primeiros se referem ao que é denotado na foto e suas conotações. São eles: os 'efeitos especiais', como introduzir uma pessoa no cenário por meio de manipulação digital, por exemplo, dando a impressão de que ela 'estava lá'; a 'pose', que se refere ao código gestual utilizado não apenas como parte da mensagem a ser transmitida, mas também estabelecendo segundo qual código cultural ela deve ser 'lida'; a 'presença de determinados objetos', traduzindo significados que se quer incorporar à imagem. Destes, apenas o primeiro não é observado nas reportagens: gestos (indicando ações), ângulos de tomada da fotografia (quase sempre encarando a lente) e objetos (como a presença de equipamentos de laboratório para falar em exame de DNA, indicando 'cientificidade', 'assepsia', 'neutralidade', ou ainda de uma estante de livros numa entrevista com um escritor) compõem os significados a serem transmitidos. 
Os três procedimentos seguintes se referem à imagem e seu contexto: 'fotogenia', em que o foco é a imagem em si, realçada por efeitos de luz, exposição e impressão; o 'uso de códigos estéticos', que em muitos casos pode 'conflitar' com as conotações de objetividade e imediatismo que se quer transmitir; e a 'sintaxe', colocação de uma imagem próxima à outra, como palavras dispostas em sequência de acordo com a sintaxe da linguagem (por exemplo, as fotos sequenciadas que produzem uma narrativa no tempo). O uso de técnicas de iluminação, obedecendo a códigos estéticos (valorizando rostos ou expressões, por exemplo), e a disposição de certas imagens como narrativas são procedimentos utilizados com menor frequência nas reportagens do jornal do que nas da revista, uma vez que esta tende a apresentar mais imagens.

Por fim, permeando todas as narrativas, está o elemento identitário do meio de comunicação em si, cujos nomes sugerem tendências e significados específicos, gerando crítica ou concordância entre seus leitores.

Os textos analisados podem ser divididos em três conjuntos de temas: 1) inclusão de pessoas com SD na sociedade; 2) atualização do conhecimento na área da genômica; e 3) o uso de (novas) tecnologias reprodutivas. São distribuídos pelas diversas seções: de Ciência e Saúde a Livros (na Veja) e de Ciência e Vida a Esportes (no Globo), chamando a atenção para o fato de que o interesse em genética e, especificamente, em SD é capaz de arrebanhar leitores com os mais variados interesses, insinuando-se como uma estratégia de tais meios de comunicação para captura de público.

\section{IMAGENS DA INCLUSÃO}

A maioria das ocorrências em ambos os meios de comunicação (em torno de $62,5 \%$ na Veja e $88 \%$ em O Globo) prioriza o tema da inclusão, com foco na diminuição do preconceito e dos entraves sociais que ele acarreta, contrastando com a situação em outros países, como Estados Unidos ou Reino Unido, nos quais a inclusão é tratada em termos primordialmente práticos. Os anos de 2006 e 2007 foram os mais prolíficos em reportagens, alavancadas pelo sucesso da novela Páginas da Vida, exibida pela 
Rede Globo de Televisão. O tema é abordado das mais variadas formas, principalmente relatos de experiências bem-sucedidas e histórias de pessoas famosas que têm um filho com a condição (como o príncipe D. João de Orleans e Bragança, o jogador de futebol Romário ou o fotógrafo Sebastião Salgado), mas também lançamento de livros, campeonatos, campanhas e outras produções culturais, tais como documentários e novelas.

Os grupos de pais que militam pela causa da SD promovem palestras, reuniões, debates, nos quais o tom confessional predomina, a fim de tornar público como é ter um filho com SD, de discutir aspectos práticos relativos aos cuidados necessários ao seu desenvolvimento e, mais importante, de transmitir mensagens positivas sobre essa experiência. Esses eventos compõem uma espécie de cenografia, um termo originado do teatro, que se refere a uma forma de "construir, adaptar, transformar e preencher um espaço dramático" (Copeman, 2009: 73), no caso, o território da SD, em que diferentes atores coreografam encontros com o intuito de cultivar um senso de unidade. Através dos meios de comunicação tais eventos são divulgados, seja com o objetivo de atrair público, seja para constatar os avanços no processo de inclusão neles manifestos e narrados.

Nos livros e blogs analisados anteriormente, a SD é implicitamente negada por meio da tentativa de eliminação de sua marca diferencial e dos limites por ela impostos. O corpo identificado pelos sinais que revelam a condição genotípica é invisibilizado pelo espírito (ou alma) sem marcas, (re)afirmando uma dicotomia. Já nas reportagens, apesar de se perceber a mesma dicotomia, a marca da SD está sempre presente, explicitada pela invariável definição das pessoas como portadores (de deficiência, da síndrome, da anomalia, do defeito genético), sugerindo uma analogia com o ato de portar um documento de identidade que é guardado ou retirado do(a) bolso(a), e que no tocante a uma condição genética não é possível. Também são referidos como 'os Down', utilizando-se uma sinédoque, caso especial de metonímia, como recurso linguístico que significa nomear um ser por uma palavra que indica apenas parte dele. Dessa forma, as conquistas são narradas dentro da moldura da identidade genética, mas num tom que se apresenta ambíguo. 
As narrativas em SD presentes nas reportagens sobre inclusão parecem evocar o conceito de grotesco da cultura popular medieval e barroca, anterior ao final do século XVIII, conforme analisado por Bakhtin (1984) no seu estudo sobre a obra de Rabelais. Nela, o grotesco e o mundano associados constituem uma alegoria das relações hierárquicas, entre algo imposto de cima e o desejo de mudança que brota nas camadas submetidas, ou entre o oficial e o marginal (a Igreja Católica, em Rabelais, e o momento político da Revolução Russa, em Bakhtin). Em sua análise, ao discutir o momento histórico de Rabelais, Bakhtin discute o seu próprio tempo.

A manifestação do grotesco e do mundano significa uma destruição simbólica, uma subversão da ordem cultural dominante e uma renovação popular, uma forma especial de vida criativa. O corpo grotesco em Rabelais, exacerbado em suas características satíricas, reforça a oposição às novas práticas repressivas no final da Renascença não apenas ao corpo, mas também à linguagem. Apresenta-se aberto, inacabado, sem totalidade corporal e identitária, aludindo à multiplicidade e não à unidade, diferente do corpo intacto, fechado e sem 'costuras', que surge como modelo de normatividade a partir do modelo clássico, e que traduz o ideal de individualidade fechada em si mesma.

A alusão ao conceito, ou ideia, de grotesco em analogia às narrativas em SD sugere um desafio à atual ordem vigente, o padrão do 'normal', que como tal considera qualquer outro modelo como inválido ou prejudicial. O corpo com SD difere do padrão harmônico e sem conflitos do corpo normal considerado belo. A presença do cromossomo extra traduz-se como desequilíbrio, e é nesse desequilíbrio que um novo equilíbrio deve ser encontrado.

A criança com SD já foi considerada como 'inacabada', conforme descrição feita por Shuttleworth em 1883 (Stratford, 1982), o que se deveria à manutenção de aspectos equivalentes ao segundo ou terceiro mês do desenvolvimento embrionário. Para Stratford, que escreve em 1982, essa incompletude ainda faria sentido, só que não tanto em termos patológicos, mas sim psicossociais. E complementa citando outro autor, Thomas Weihs, cujas palavras chamam a atenção para o fato de que, se por um 
lado essa cobertura corporal insuficiente destaca e separa a criança com $\mathrm{SD}$, por outro é o que desperta um senso de proteção e compaixão em relação a ela por parte dos demais.

A presença da $\mathrm{SD}$, como qualquer outra condição que implica uma modificação no padrão corporal considerado 'normal', traz uma quebra, uma alteração drástica no campo perceptual, principalmente em termos visuais, que deve ser racionalizada e contida e que se relaciona ao poder do olhar. É pela percepção dos sinais pela pessoa 'normal' que a pessoa com SD se torna 'outro', estranha e ameaçadora em sua 'desordem' e consequente possibilidade de 'fragmentação', reverberando o que seria, em termos lacanianos (Lacan, 2007), a imagem de um primitivo estado em que o corpo é experienciado como fragmentado. A racionalidade é um dos elementos que fazem a contenção do corpo deficiente e protegem a pessoa 'normal' da angústia que a desordem/fragmentação inspira. Na tentativa de evitar o desconforto, o corpo deficiente é reconstituído imaginariamente como forma de reparar a quebra perceptual, recuperando sua completude/ organização (Davis, 1997). A tendência é polarizar, dividindo os corpos entre capazes e incapazes, completos e incompletos, disciplinados e indisciplinados. A reafirmação constante das vitórias alcançadas pelas pessoas com SD, ou a exibição daquilo que são capazes de fazer, sugere esse efeito, livrando as pessoas 'normais' da percepção do corpo deficiente.

Os sinais da SD parecem dissociar-se da totalidade corporal; os olhos amendoados traduzem a vida humana individual e autossuficiente, mas a boca com a presença de uma língua protusa expõe e torna-se sinônimo do retardo mental. O Filho Eterno, livro de Cristovão Tezza (2007), provoca desconforto ao evidenciar o desafio que a SD impõe ao padrão de normalidade aceito socialmente, desafio este que precisa ser arduamente negado. No livro, a incompletude do filho com SD aparece na falta de ligação deste com o mundo à sua volta.

A crítica ao livro, apesar de ressaltar a beleza da narrativa, é carregada de adjetivos valorativos disfóricos em relação ao personagem que minimizam o incômodo diante do exposto pela realidade ficcional. A crueldade é considerada a principal qualidade do livro, em que a brutalidade 
das palavras é comparada ao uso do termo 'mongoloide' nos anos 80 para designar pessoas com SD, resquício da linguagem evolucionista usada por Langdon Down ao descrever a síndrome - comparando o seu fenótipo com raças consideradas 'inferiores'-, mas também da relação entre as palavras e as coisas pela similitude. Ainda segundo a crítica, o personagem considerado como alter ego do autor é, de certa forma, 'redimido' no final do livro pelo momento fugaz de harmonia familiar, traduzindo o cotidiano sem questionamentos que apazigua a vida de todos.

A importância dos olhos amendoados como elemento identitário na SD fica evidente no manifesto lançado no site da campanha "Ser diferente é normal", 7 criada pelo Instituto MetaSocial contra todo tipo de discriminação e segregação, utilizando a SD como bandeira e símbolo desse desejo de inclusão, com o intuito de "mostrar ao Brasil e ao mundo que ser diferente é normal". Para tanto, utiliza-se de uma ferramenta tecnológica que fotografa as pessoas e, por meio de manipulação digital, produz uma segunda foto 'como se' elas tivessem SD. Ao se observar atentamente a transformação, percebe-se que a mudança se dá unicamente nos olhos, elemento-chave no reconhecimento da imagem de alguém com a síndrome. Porém, essa mesma modificação já se apresenta alterada: o formato 'típi-

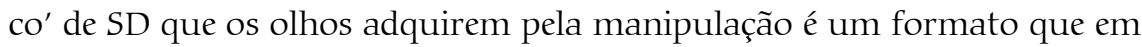
si já sofreu uma correção plástica, isto é, são olhos de alguém com SD que se submeteu a uma correção de formato para modificar o estereótipo típico da síndrome. Essa ferramenta aparece numa das ocorrências do Globo, em $2007,{ }^{8}$ quando foi veiculada na televisão com a participação de diversas atrizes, com texto que apontava para os "pequenos detalhes que fazem muita diferença" e conclamando o público a dizer não ao preconceito, começando a "ver o mundo com outros olhos".

Apesar de alardear o repúdio à discriminação e a defesa da aceitação da diferença e sua inclusão, o que essa campanha indiciariamente promove é a literalização da imagem do 'mesmo'. Dito de outra forma, para que a inclusão seja possível, é necessário que todos se apresentem com a mesma face, a face da SD tornada 'normal', eliminando diferenças e tornando-se 'mesmo'. 
Ao se analisarem as edições entre 2000 e 2009 , podem-se acompanhar as sutis modificações no vocabulário usado para se referir às pessoas com SD ou apenas à $\mathrm{SD}$, as quais seguiram o compasso do mapeamento do genoma humano e dos resultados das pesquisas na área da genômica e das tecnologias reprodutivas.

Uma importante modificação no discurso, que aparece em setembro de $2006,{ }^{9}$ diz respeito à denominação da SD não mais como doença, mas como acidente genético. A renomeação ocorre no nível do discurso não especializado, uma vez que a SD continua a ser definida na Classificação Internacional de Doenças (CID) no capítulo de "Malformações congênitas, deformidades e anomalias cromossômicas". Contudo, esse é um dos elementos importantes do movimento de inclusão que surge no final da década de 1990 e que ganha força no início do novo milênio, aliado ao rechaço à ideia de prevenção por meio da interrupção do nascimento de crianças com SD diagnosticadas intraútero.

O discurso da inclusão nas narrativas analisadas apresenta-se ambíguo ao tentar conciliar a imagem múltipla da pessoa com SD, com capacidades e limitações, à da imagem unificada da normalidade, mas que é apresentada atrelada a um excesso de adjetivos que mais reforçam a segregação do que incluem. Ao veicularem alguma conquista alcançada por essas pessoas, a presença de advérbios tem o papel de frisar a deficiência, acrescentando uma circunstância que modifica o sucesso narrado. Por exemplo, após falar sobre as várias atividades de um rapaz com SD que toca flauta doce, é dito sobre ele: "Obviamente, como portador de deficiência mental, (...) jamais chegará a ser um grande concertista. Mas não é isso o que se espera dele"; ou ainda: "os deficientes não apenas estão sendo incentivados a frequentar a escola até o colegial - sempre recebendo atenção especial dos professores, evidentemente - como também sendo preparados para o mercado de trabalho" ${ }^{10}$ Não é a constatação da limitação que chama a atenção, mas a presença da comparação com a normalidade que permanece camuflada na forma de um self ativo.

Nos sentidos e imagens sobre inclusão veiculados nas narrativas, da mesma forma que no grotesco medieval, percebe-se uma tentativa de 
desafiar a ordem vigente estabelecida pelo padrão de normalidade, por meio da exposição de como as pessoas com SD vivem, agem e participam da sociedade. Contudo, essa tentativa se enfraquece ao ser revelado o seu caráter ambíguo que, apesar de clamar por uma mudança da moldura atual, reafirma o modelo vigente, entrega-se a ele como único possível e define uma única forma de ser humano. As pessoas com SD são confinadas numa categoria homogênea globalizante (são especiais, dóceis, prestativas, únicas, iguais a qualquer criança), e sua individualização só acontece se tornadas normais, ou seja, quando as conquistas são narradas e destacadas. O que poderia ser multiplicidade de vozes prossegue como monólogo.

\section{Escolhas Circunstanciais}

Dois outros temas são privilegiados pelas reportagens: a atualização do conhecimento na área da genômica (cerca de 12,5\% na Veja e 7\% em O Globo) e o uso de (novas) tecnologias reprodutivas, que incluem técnicas de rastreamento e diagnóstico pré-natais e de reprodução assistida (em torno de 25\% na Veja e 5\% no jornal O Globo). Em ambos, a SD aparece como o exemplo mais comum, às vezes apenas nomeada, por se tratar de uma das condições genéticas mais frequentes e com maior sobrevida e ser facilmente reconhecida pelo público em termos fenotípicos, o que contribui para tornar a notícia divulgada mais significativa para o público em geral. Os dois grupos são analisados em conjunto por envolverem aspectos comuns à sua discussão, buscando-se identificar a forma como genes, herança genética, testes de rastreamento e diagnóstico e técnicas de reprodução assistida são apresentados ao público e como são enfocados aspectos como informação, risco, escolhas e prevenção em relação à SD.

As narrativas relacionadas à atualização do conhecimento em genômica buscam promover o letramento do leitor nos avanços ocorridos na área, num processo que não apenas informa, mas tenta tornar significativo o conhecimento por meio da utilização de figuras de linguagem e elementos imagéticos que permitam criar uma interface entre algo distante e abstrato, pertencente ao âmbito esotérico, e o cotidiano das pessoas. 
As reportagens mais antigas, veiculadas entre 2000 e 2002, utilizam um tom espetacular para divulgar certos avanços e perspectivas entusiastas para recebê-los. São narrativas de progresso que não apenas testemunham os feitos considerados importantes, mas traçam percursos futuros, povoados de promessas de que as dificuldades enfrentadas num momento e área específicos serão vencidas pela ciência e trarão alívio ao sofrimento humano causado por doenças (como a inserção num indivíduo de "cópias normais de um gene defeituoso, corrigindo o seu genoma"). ${ }^{11}$ Substantivos como 'descoberta', 'revelação', 'decodificação', 'segredo', 'mapa', 'empreitada' e adjetivos como 'audaciosa', 'surpreendente', 'ambicioso', 'promissoras' ilustram os recursos figurativos utilizados para descrever algo que se apresenta como novo e que acena para inúmeras possibilidades, ainda que algumas fantasiosas, de entendimento do ser humano por meio do conhecimento de seu genoma ou dos modelos animais, ${ }^{12}$ isto é, pela comparação com o genoma de outros organismos, principalmente camundongos.

O mapeamento do cromossomo $21 \mathrm{em} 2000$ merece destaque pelo marco que estabelece em relação à $\mathrm{SD}$, como possibilidade de uma 'cartografia' da condição. Tanto a revista Veja quanto o jornal O Globo ${ }^{13}$ publicaram matérias sobre o assunto, cujo pano de fundo alude a uma competição, nos moldes neoliberais, entre os cientistas envolvidos no estudo e os que também participam do Projeto Genoma Humano.

A metáfora do código genético, introduzida em 1944 no âmbito da pesquisa em biologia molecular, com o objetivo de descrever e entender o processo de síntese de proteínas e que deu origem a uma série de outras metáforas (Knudsen, 2005), aparece como metáfora implícita, ou seja, sem a identificação clara entre o tópico e o veículo, e serve de alicerce para a apresentação do mapeamento do cromossomo 21 nas matérias de ambos os meios de comunicação.

Numa dessas matérias (Veja), o cromossomo é definido por meio do uso de um símile, isto é, uma expressão metafórica que explicitamente compara o veículo e o tópico enfatizando a similaridade: "uma espécie de novelo no qual está emaranhada uma longa cadeia de substâncias químicas chamadas genes". 
Na outra ( $O$ Globo), o recurso escolhido foi o imagético, com apresentação de esquemas com o intuito de definir elementos como DNA e genes, ao mesmo tempo narrando o processo de transmissão do material genético, com as contribuições materna e paterna, espacializando-o na célula. Outra imagem traz um diagrama do cromossomo 21 , assinalando as zonas críticas para diversos agravos e destacando a SD como a principal 'doença' associada. $\mathrm{O}$ texto principal da reportagem é um desdobramento do esquema, considerado denotativo, conotando-o.

A SD aparece associada ao estudo das proteínas, ${ }^{14}$ as quais são qualificadas como o "segredo da nova medicina", uma espécie de maestro com poder decisivo de ação para "orquestrar o funcionamento do corpo", e são definidas como "constituintes básicos de qualquer ser vivo - que interagem a todo momento". Disso resulta uma "sopa química" ou "sopa de vida", cuja "receita" se encontra no genoma, uma metáfora que remonta a um processo alquímico, trazendo implicitamente ideias de transmutação de substâncias espúrias em nobres, de criação do elixir da vida, ou 'panaceia', que traria a cura para todos os males e, em última instância, a imortalidade. Também receberam destaque jornalístico o que foi chamado de a descoberta da "molécula Down"15 e do gene "causador de Down", ${ }^{16}$ acenando para a possibilidade de intervenção no nível molecular em pessoas com a condição.

A distância que existe entre a abstração da pesquisa molecular, ainda que já aplicada a 'pessoas reais', e o leitor não parece ser totalmente transposta por ação das reportagens. Por não solicitar diretamente aos leitores escolhas circunstanciais em razão do que é divulgado, as reportagens (à exceção daquelas que emitem opiniões pessoais) sugerem uma isenção de qualquer cunho valorativo ou discriminatório ao apontarem para um padrão de normalidade desejável e intrínseco às pesquisas.

A ambivalência que caracteriza os genes no discurso não especializado, já comentada anteriormente, aparece nessas narrativas (e também nas narrativas em tecnologias reprodutivas) na qualificação de algo definido ao mesmo tempo como abstração e concretude e colocado no lugar do conceito científico de genótipo. O que é do domínio da especulação 
converte-se em predição diante da probabilidade de riscos futuros, e como predição torna-se significativa e poderosa porque as duas vertentes sobre o gene se mesclam: a abstrata especulativa, de um lado, e a material corporal, de outro. Alusões a mecanismos também estão presentes nos textos, evocando um modelo de corpo como máquina e dos genes como partes desse mecanismo, o qual pode estar 'danificado', 'defeituoso', com 'problemas' ou 'alterado'.

$\mathrm{Na}$ área da genômica, a pesquisa com células-tronco encontra-se intimamente ligada à medicina reprodutiva, especialmente a procedimentos de fertilização in vitro. As definições desse tipo de células referem-se a modelos emergentes de vida humana nos quais os elementos que compõem o indivíduo podem ser extraídos, recombinados e, mais importante, redefinidos. O destaque é a funcionalidade da célula e a possibilidade de redesenhá-la por meio de tecnologia aproveitando sua capacidade 'natu$\mathrm{ral}^{\prime}$, tornando-a objeto de biovalor em termos globais (Franklin, 2005). ${ }^{17}$

As narrativas em tecnologias reprodutivas, apesar de concernentes ao casal e suas decisões reprodutivas, referem-se à mulher, principalmente àquela com mais de 35 anos, ponto de corte que marca um risco aumentado para condições resultantes de anomalias cromossômicas, entre elas a SD. A idade paterna é relacionada a possíveis problemas numa reportagem em edição especial da Veja no ano de $2005 ;{ }^{18}$ porém, são reduzidos a condições de pouca gravidade, recaindo sobre a mulher o peso das consequências do envelhecimento dos óvulos.

Mulheres são vistas de maneira geral como as responsáveis pela manutenção e transmissão das histórias familiares e as mais envolvidas em procurar aconselhamento ou testes genéticos quando diante de uma doença genética existente ou potencial (Emslie, Hunt \& Watt, 2003). Pela ênfase dada nas reportagens, sugere-se que possam ser as mais beneficiadas pelo uso das novas tecnologias, e que estas permitiriam uma mitigação do risco envolvido em suas histórias, tornando-as implicitamente responsáveis pelo futuro genético da família.

Tecnologia biomédica é criada e desenvolvida no compasso das mudanças no conhecimento biomédico, das referências legais, dos valores 
culturais estabelecidos que podem ou não ser contestados, e é instrumentalizada por pessoas no exercício de suas identidades sociais (Rapp, 2000). A esfera das tecnologias reprodutivas traduz-se como um espaço biopolítico, no qual questões como aborto, infertilidade, doação de gametas e decisão reprodutiva são abordadas em suas múltiplas faces: tecnológica, política, legal e ética. A necessidade de escolha, suscitada pelos avanços da biomedicina, conecta-se a questões que envolvem algum tipo de julgamento diante de probabilidades e que se misturam com medo, expectativa e esperança. A possibilidade de intervenção em situações de infertilidade, além de incluí-la na categoria de doença tratável, operacionaliza o lidar com a plasticidade de características vitais humanas, potencializando-as (Rabinow \& Rose, 2006).

Entidades limítrofes como óvulo, esperma, ovo, células-tronco, que têm sua existência autônoma destacada por tais tecnologias, suscitam discussões sobre as fronteiras da vida, sobre novas formas antes impensáveis de conectá-las e organizá-las, sobre as definições de organismos vivos, seu uso e o destino de elementos que compõem a própria vitalidade humana e que saem do escopo da definição de genes (Rose, 2007). Sua presença no domínio público é inconteste e tais entidades tornaram-se sujeitos de intensa discussão biopolítica (Franklin, 2007; Culley \& Hudson, 2009; Lynch, 2009; O'Riordan \& Haran, 2009; Watts, 2009; Williams et al., 2009).

A noção de 'genes alterados' aparece em 2000 numa extensa reportagem relacionada a exames preventivos, ${ }^{19}$ o chamado check-up, e que inclui técnicas de rastreamento pré-natal, como a ultrassonografia morfológica e a translucência nucal, salientadas como importantes ferramentas indicativas de risco para alterações cromossômicas e malformações fetais. A materialidade dos genes é explicitada na definição "microscópicas sementes protéicas do núcleo das células", ao mesmo tempo que eles são definidos como agentes causadores de algo já presente, apenas à espera do momento para se manifestar, com poder de decisão sobre o "futuro biológico das pessoas". Apesar da referência a aspectos moleculares, o foco ainda é o corpo molar ressignificado: tais exames voltam-se não mais para pessoas doentes, mas para aquelas aparentemente saudáveis visando 
a encontrar o 'mal' (ou suscetibilidades) antes que ele se revele (por exemplo, obstrução nas coronárias, ou perda de massa óssea) e a melhorar o indivíduo e o seu viver.

Nessa ótica, o corpo é entendido como não confiável, passível de conter algum elemento hostil, devendo, portanto, ser vigiado e controlado. No texto e nas imagens, a apresentação de novas tecnologias reafirma a narrativa da conquista do espaço interno, com a presença dos mesmos elementos das viagens espaciais: um alto nível de tecnologia, a fragilidade humana e a salvação futura. O poder de ação na vida das pessoas mostra como a biotecnologia está entranhada no tecido social, determinando escolhas dentro e fora do âmbito da saúde, ora proporcionando mudanças que alteram o estilo de vida e previnem manifestações de doenças futuras, ora dando a oportunidade de 'salvação' em casos em que as alterações já estão internamente presentes, prestes a eclodir.

O oferecimento de testes genéticos é ainda incipiente nesse momento, e estes se apresentam como a "ponta-de-lança tecnológica dos checkups". O "exame dos genes" torna-os ameaças latentes ao revelarem as "predisposições biológicas": uma caixa de Pandora prestes a liberar males insuspeitados (ainda que a esperança esteja entre eles), ${ }^{20}$ ou ainda como uma bomba-relógio que pode ter sua explosão adiada ou ser desmontada por ações (médicas) eficazes.

Anos mais tarde, no final de 2008, a inclusão de consultas de aconselhamento genético e de exames de DNA no Sistema Único de Saúde (SUS), a partir de 2009, tornam o corpo molecular foco da discussão sobre a identificação precoce de doenças e suscetibilidades como forma de prevenção, por meio da análise de "mutações genéticas". ${ }^{21}$ A reportagem parte de um panorama que sugere um amplo acesso a tais procedimentos e vai paulatinamente reduzindo as áreas possíveis de aplicação. Prevenção aqui se relaciona ao fornecimento de informação relevante, capaz de contribuir para forjar escolhas de casais que desejam ter filhos e que têm o risco aumentado para alguma condição geneticamente determinada. Aspectos econômicos são também enfocados (custo do teste), sugerindo uma mercadoria que, se não fizer parte do sistema público de saúde, será acessada 
por poucos. Um dos exemplos utilizados nessa reportagem é a SD. Duas imagens compõem uma narrativa pela proximidade física com que são dispostas: de um lado, a imagem indiscutivelmente 'real' de uma criança com SD; do outro, a imagem de um gráfico representando o sequenciamento de DNA, na qual a presença de uma mão enluvada, de modelos representando moléculas e de uma lupa dão o caráter científico, objetivo e revelador da identidade em termos genéticos.

Ao longo desses nove anos, de 2000 a 2009, pode-se acompanhar os avanços nas técnicas de rastreamento e diagnóstico pré-natais, o que possibilita detectar alterações cada vez mais precoces, de maneira menos invasiva e com menor risco. Principalmente o refinamento da qualidade das imagens, com consequente poder de visualização, reafirma a ideia de 'janela' independentemente da percepção da mãe e permite acompanhar e, acima de tudo, intervir no desenvolvimento fetal. A imagem obtida deixa de ser representação do real para se tornar o real em si; ver significa saber.

Testes para marcadores bioquímicos, translucência nucal, ultrassonografia morfológica, doppler de ducto venoso, ecocardiografia, biópsia de vilo corial, amniocentese são alguns dos exames oferecidos no pré-natal e com os quais o público em geral vai se familiarizando. ${ }^{22}$ São incluídos na 'agenda' para a futura mãe ou casal, destacando com isso seu caráter individualizante, como atividades e tarefas pessoais a serem marcadas e cumpridas, mas também coletivo, concernentes às mulheres grávidas em geral e, no caso dos exames diagnósticos, àquelas com risco aumentado, detectado em rastreamento prévio ou por aspectos como idade ou história familiar. A incorporação crescente de vocabulário especializado justifica o seu uso não apenas como ferramentas rastreadoras ou diagnósticas para confirmar suspeitas sobre malformações, mas como produtos 'científicos' que concretizam memórias mediadas do bebê antes do parto, dentre elas a determinação do sexo, já incorporadas à leitura social dos processos de gravidez e parto. Mas o que acontece quando esses resultados revelam algo diferente do esperado? 
Subjacente às tecnologias de rastreamento e diagnósticas, um padrão de normalidade está definido em termos biomédicos, e o seu propósito é detectar variações nesse padrão o mais precocemente possível e com menor margem de erro, de forma a permitir ações relevantes. Esse padrão está presente nas reportagens, e estas sugerem que, enquanto determinados significados são criados e revelados durante ou após os testes, outros são silenciados.

Por conseguinte, as imagens veiculadas nas reportagens sobre rastreamento e diagnóstico pré-natais reproduzem o padrão e traduzem uma experiência agradável, casais numa expectativa positiva quanto ao nascimento, ou um caso grave, mas que teve um desenlace satisfatório. Os problemas são narrados apenas textualmente, sem imagens, como possibilidades remotas que podem ser, se não evitadas, contornadas por ações médicas precoces. O imaginário sobre fetos com algum tipo de anomalia não aparece nesse tipo de narrativas; o tom dado ao texto transmite cientificidade, neutralidade e objetividade, com o claro propósito de informar mas também de prescrever.

Numa das reportagens, o aconselhamento genético é visto como uma forma de "proteger a saúde da família", ${ }^{23}$ em outra, as novas tecnologias utilizadas nos exames de pré-natal são consideradas responsáveis por tornar "a gravidez mais segura", como forma de controle e previsão sobre aquilo que é do domínio da natureza. A ideia de mais segurança (ou de menos risco) refere-se aqui à "detecção de eventuais malformações" ${ }^{24}$ e não à prevenção de novos casos. Ao mesmo tempo, a expressão sugere um aplacamento da ansiedade inerente a qualquer gestação quanto à saúde do feto - o que coloca a mulher grávida no centro de discursos sobre risco - e da ansiedade que resulta da probabilidade aumentada por fatores diversos a ser confirmada pelos exames, o que irá requerer uma intensificação do monitoramento (Lupton, 1999).

As reportagens na área de reprodução assistida, que se referem quase que exclusivamente à fertilização in vitro, têm o caráter de produto ofertado (haja vista o tipo de público ao qual são direcionadas), como opções tecnológicas naturalizadas para solucionar problemas. São apresentadas 
como última, às vezes única, possibilidade para certas pessoas terem filhos, desejo esse subentendido como natural, normal e universal. Conforme apontado por Sarah Franklin (1997), a busca por soluções pode ser definida em termos narrativos como uma tentativa de se alcançar algo que não encontra fechamento (um filho) por uma quebra numa sequência progressiva de eventos (o processo reprodutivo).

A ideia subjacente é a de 'ajuda' que a biomedicina presta à natureza, ainda que seguindo os ditames desta última, transmitindo uma imagem de capacidade de recuperação, ao corrigir 'anomalias' por meio do controle tecnológico. A intervenção da tecnologia num processo considerado como 'natural' provoca rearranjos nos laços de parentesco - por exemplo, a presença de um(a) doador(a) - com a inclusão de novas formas de relação estabelecidas com a ciência e a tecnologia (Franklin, 1997, 2005; Culley \& Hudson, 2009; O'Riordan \& Haran, 2009).

Técnicas de reprodução assistida são veiculadas inadequadamente como tratamento, transmitindo a ideia de tentativa de adequação à norma, muito mais em termos sociais do que biológicos, uma vez que a reprodução assistida não cura a infertilidade, apenas a contorna. E, acima de tudo, são delineadas como tecnologias de esperança (hope technologies), para usar as palavras de Franklin (1997), reafirmando valores tradicionais de família por meio da esperança no progresso tecnocientífico e, em última instância, da esperança de ter um filho.

Os procedimentos de reprodução assistida, apesar do caráter de novidade transmitido no texto, são trazidos ao público como práticas já estabelecidas em centros privados de reprodução humana no Brasil, e os casos bem-sucedidos são citados para validá-los, sobrando pouco espaço para os aspectos exaustivos e dolorosos do processo. Entretanto, sabe-se que apesar da grande repercussão que tais procedimentos geraram, como narrativas de progresso rumo à conquista do desconhecido, seus limites ainda são grandes, os insucessos frequentes, e o nível de incerteza produzido é significativo (Franklin, 1997; Rabinow \& Rose, 2006). As histórias individualizadas apresentadas como exemplo nas reportagens fazem sentido porque, ao serem lidas em retrospecto, marcam o fechamento de uma 
vivência satisfatória. No entanto, os insucessos, se narrados, deixariam a narrativa em aberto, sem um sentido de finalização, o que a tornaria ambígua e impediria que o leitor com ela se identificasse.

A temporalidade linear sequencial do processo reprodutivo está presente nos esquemas que representam o passo a passo simplificado do processo, como numa receita, com o objetivo de informar o leitor. Desenhos representando um homem e uma mulher mantêm a conexão com a dimensão humana palpável, impedindo que elementos como óvulos, espermatozoides, citoplasma e cromossomos ganhem completa autonomia e se destaquem do todo que é a pessoa real. A referência ao que é considerado como "avaliação genética do embrião" em busca de qualquer "anomalia genética" 25 é explicitada em termos citogenéticos: alterações na estrutura dos cromossomos e erros no pareamento durante a divisão celular. A identidade familiar é representada mais pelo fenótipo do que o genótipo, e de forma similar ao gene, o cromossomo condensa as características corporais apresentadas pela pessoa ao mesmo tempo que representa aquilo que as determina.

Nas narrativas em reprodução assistida, a implantação de embriões, permitindo selecionar aqueles saudáveis, surge como prevenção possível, sem, contudo, ser nomeada explicitamente como tal, e a discussão subliminar diz respeito à eliminação de embriões 'defeituosos' em favor do nascimento de crianças sadias. Em ambos os meios de comunicação, o discurso torna-se escorregadio, carregado de subtextos, que são lidos de acordo com o enquadramento (no sentido fotográfico) feito pelos diferentes leitores. A discussão suscitada pelo pronunciamento de especialistas, entrelaçando os círculos esotérico e exotérico, gira em torno dos aspectos médicos, éticos e legais da manipulação de material genético e do diagnóstico pré-implantação, com consequente seleção de embriões, deixando um rastro de ambiguidade e incerteza características dos tempos considerados pós-genômicos.

Conforme apontam Sarah Franklin e Celia Roberts (2006), o processo de fertilização in vitro difere do diagnóstico pré-implantação na medida em que este último envolve uma dimensão genética, enquanto o primeiro 
atua nos níveis hormonais do organismo feminino, isto é, no corpo molar. Apesar de o diagnóstico pré-implantação usar a plataforma da fertilização in vitro e dela depender, constitui-se como uma assistência à hereditariedade e não à concepção, uma vez que tem entre seus objetivos evitar a transmissão de determinadas condições genéticas. Dessa forma, a naturalização da fertilização in vitro se agencia mais facilmente como auxílio à natureza do que a do diagnóstico pré-implantação, na medida em que este intervém impedindo o curso 'natural' do processo reprodutivo e da hereditariedade.

A ligação com o passado, o parentesco e o processo mecânico linear deixa pouco espaço para probabilidades e outros fatores intervenientes. A noção de latência, associada à de probabilidade de aparecimento, configura o discurso do aconselhamento genético. Por sua capacidade de apontar, em termos corpóreos, para aquele que fala, o gene promove uma junção entre fenótipo e genótipo. É a corporalidade dos genes que faz a ligação entre a pessoa e os conceitos estatísticos probabilísticos (distribuição estatística) para torná-los significativos, pela mediação do profissional responsável pelo aconselhamento - no caso do Brasil, o geneticista -, permitindo escolhas circunstanciais com base nessa nova informação sobre si. Torna-se necessário que o indivíduo foco do aconselhamento seja capaz de se ver simultaneamente como o 'eu' com o qual costumava identificar-se e também por meio do seu perfil de risco, construído com base em informações estatísticas incorporadas à sua história individual e familiar. Existem diferenças entre o risco comunicado pelo profissional de saúde e aquele percebido pelo paciente. Nesse sentido, o que o paciente entende como risco é mais amplo e abarca não apenas a probabilidade, mas o valor que a pessoa atribui aos desfechos possíveis, moldado segundo pensamentos e crenças que atuam como filtros no processo de tomada de decisão.

Em sentido amplo, risco pode ser definido como uma forma de ordenar a realidade, de representar eventos a fim de torná-los governáveis por meio de técnicas específicas e voltado para determinados fins (Dean, 1999). Seu caráter probabilístico impede que as previsões de adoecimento sejam lidas como inexoráveis, gerando incerteza e ansiedade diante da multiplicidade de aspectos a serem considerados (Castiel, 1999). Na biopolítica 
exercida nas sociedades ocidentais contemporâneas, a noção de risco está associada a estratégias epidemiológicas de redução de risco em termos populacionais, à administração de grupos considerados de alto risco e à identificação de indivíduos em risco, envolvendo intervenções preventivas e modificando a forma como eles são governados por outros e por si mesmos. A centralidade que o discurso sobre risco, insegurança e precaução adquire parece indicar uma nova forma de problematização que desafia o modelo de 'governamentalidade' liberal avançada (Miller \& Rose, 2008a; Dillon \& Lobo-Guerrero, 2009; Lentzos \& Rose, 2009).

O estabelecimento e a percepção de risco, ainda que ofereçam ferramentas para decisão, não podem de forma alguma antecipar a extensão das consequências de tais decisões. Em alguns casos, um excesso de informação convive com a dificuldade em articulá-la e significá-la satisfatoriamente. Testes levam a outros testes, que carregam em si seus próprios riscos de discordâncias. Nesse panorama, o direito a não querer saber pode soar absurdo, estimulando sentimentos individuais de culpa (Castiel \& Álvarez-Dardet, 2007).

A forma como as reportagens apresentam as diferentes técnicas como estratégias para lidar com e minorar a existência de riscos concernentes à população em geral, em termos epidemiológicos, ou a determinados indivíduos, em particular, reforça a posição de que o gerenciamento do risco, feito por meio da escolha por tal ou qual técnica, pertence à esfera individual privada. Por conseguinte, novas relações se estabelecem, interligando conhecimento especializado e diferentes formas de estar no mundo, através de inúmeras mediações, como de profissionais de saúde e dos meios de comunicação, por exemplo. A introdução do eixo genético no entendimento de doenças expande a sua compreensão, tornando-as assunto familiar e não apenas pessoal.

Em se tratando de SD, o elemento de risco associado nas narrativas, que é apresentado quantitativa e qualitativamente, é a idade materna avançada e o envelhecimento dos óvulos, podendo levar a erros na divisão celular que causariam a trissomia do cromossomo 21. No entanto, o caráter 'natural' com o qual esse fenômeno é revestido esvazia a noção de prevenção via 
"consciência do risco" (Castiel, 1999: 63), ainda que seja claro que nem sempre o acesso à informação é suficiente para gerar estratégias preventivas (Castiel, 1996, 1999). Por sua vez, a ação dos grupos de pais militando a favor da inclusão e contra a discriminação desses indivíduos, e testemunhando sobre as melhorias significativas alcançadas em aspectos como estimulação precoce, acompanhamento clínico, educação e participação na comunidade, parece ter um papel fundamental. Subliminarmente, as imagens e os significados associados à SD, difundidos e reafirmados socialmente, somam-se como fatores preponderantes que determinam a escolha por realizar ou não testes pré-natais para determinar a presença da SD no feto ou, de forma mais definitiva, a interrupção da gestação.

O principal elemento que perpassa todas as narrativas em tecnologias reprodutivas, tanto de diagnóstico pré-natal quanto de reprodução assistida, é a questão das escolhas que se apresentam como possíveis diante da identificação de uma condição já existente no feto ou no embrião. Para Rapp (2000), tais tecnologias fazem sentido quando o acesso ao aborto é garantido legalmente.

É dito que a deteç̧ão pré-natal de 'problemas' como a SD permite a preparação e a escolha de estratégias de tratamento a serem executadas durante a gestação ou imediatamente após o parto. Contudo, a decisão sobre manter ou interromper a gestação não faz parte do leque de escolhas possíveis, não apenas por crenças ou valores individuais ou de grupos sociais, mas fortemente justificada por seu aspecto (i)legal.

A relevância desse aspecto encobre outros matizes importantes da discussão, como a incômoda perspectiva de se fazer uma escolha que soe como eugênica, ao se determinar quais formas de ser humano poderiam ser evitadas. ${ }^{26}$ Percebe-se, nos interstícios do escopo das tecnologias reprodutivas, duas fortes tendências que se conectam de forma conflitante: os direitos reprodutivos, cuja regulamentação no Brasil encontra-se ainda sob forte influência de caráter religioso, e os direitos das pessoas com deficiências, contrapondo temas como aborto e inclusão.

O que antes era entendido como fado na biopolítica contemporânea torna-se oportunidade, esperança, alento, com alívio do peso do 
determinismo, embora em muitos discursos ainda soe como tal. A possibilidade oferecida pelas intervenções no nível molecular de escolher entre ter ou não um filho afetado por uma condição específica suscita intenso debate na tentativa de definir um possível recrudescimento ou novas releituras de uma postura eugênica.

O termo eugenia foi criado por Francis Galton em 1883, como uma estratégia biopolítica de melhoramento da 'raça humana'. De cunho darwiniano, o foco era colocado não no indivíduo, mas na população territorializada numa nação e submetida a uma governança interna (Foucault, 2003d). Os indivíduos que compunham essa população seriam avaliados em termos da sua 'qualidade' evolutiva, manifesta por suas aptidões físicas e mentais: aqueles considerados como os melhores seriam encorajados a procriar livremente para a melhoria do corpo político, a chamada eugenia 'positiva', enquanto os considerados de nível inferior, ou menos aptos, devido a algum tipo de defeito ou doença, seriam limitados em suas opções reprodutivas, a eugenia 'negativa', como forma de evitar o peso econômico e social advindo de uma situação de degenerescência que levaria ao enfraquecimento da coletividade. No começo do século XX, uma nova onda higienista teve lugar ressaltando técnicas de cuidado individual à saúde física e moral, configurando outra estratégia estatal além daquela eugênica, cujo foco era a reprodução. A face eugênica assumida pelo regime nazista foi resultado da conjunção de numerosas outras tendências e debates sobre raça; entretanto, constitui, nos dias atuais, a referência máxima de eugenia, com seus fantasmas, a ser evitada. O termo eugenia ainda é considerado como uma espécie de rótulo com múltiplos usos, de grande valor simbólico, aplicado a situações de pesquisa em diversas áreas, seja para enfraquecer determinado enfoque considerado controverso, seja para estimular novos rumos não aventados por questões de preconceito (Ramsden, 2009).

A biopolítica molecular contemporânea é considerada por críticos como Giorgio Agamben (1998) como ainda tendo o seu foco intrínseco no controle e na eliminação de elementos estranhos a um corpo político, por meio de uma tanatopolítica, ou política de morte; entretanto, autores como 
Paul Rabinow e Nikolas Rose (2006) argumentam que o que a caracteriza não é passível de ser descrito como mera repetição ou variação de um passado. Após a Segunda Guerra Mundial, o interesse da genética voltouse para a busca da origem das doenças no âmbito da saúde individual, com o foco em elementos como os genes e suas funções no nível molecular. Ainda que, hoje, a vida esteja sob escrutínio em termos valorativos, o que está em questão não diz mais respeito a um corpo político territorializado, cuja qualidade deve ser maximizada para competir com outro, mas a indivíduos que são instados a assumir escolhas relativas à sua saúde pessoal ou familiar.

Ao mesmo tempo que o Estado manteve determinadas funções de legislar sobre a saúde (por exemplo, sobre padrões de qualidade de serviços básicos como água e esgoto, ou sobre comida), observou-se um movimento de redução da responsabilidade pela garantia da saúde individual, com emergência de serviços privados de saúde e com delegação aos próprios indivíduos da responsabilidade por se administrar (Miller \& Rose, 2008a). Assim, a biopolítica contemporânea exerce-se nos microespaços dos lares e comunidades em busca de qualidade de viver, o que inclui questionamentos e ações com respeito à prevenção ou término da vida, como na contracepção, diagnóstico pré-implantação, aborto ou eutanásia, que emergem em consonância com a pluralidade de molduras por meio das quais os indivíduos enxergam o mundo.

O corpo flexível, aberto à possibilidade de intervenção molecular a fim de ser melhorado em seus aspectos vitais, é contraposto a determinadas referências corporais consideradas mais desejáveis, numa sociedade em que o individualismo e a oportunidade de escolha apresentam-se como valores básicos, alinhados com os modos de subjetivação implícitos nos modelos liberais avançados ocidentais (Rabinow \& Rose, 2006). Todavia, parece inadequado considerar essa situação como um revigorar do pensamento eugênico. Os cenários são diferentes, e as interações que hoje se observam são mais intersticiais. O desejo de pais por evitar ou minorar o sofrimento de seus filhos com algum tipo de deficiência ou a dor da perda de um deles, que os fazem se engajar num movimento para financiar pes- 
quisas em busca de tratamentos ou cura, ou em prevenção ativa pela restrição de nascimentos, não parece se encaixar na ideia de melhoramento do corpo político de uma determinada nação por meio de ações governamentais. Antes, configura-se como um redelineamento de valores éticos e responsabilidades que permita melhor administrar a existência social e biológica, e é expressão daquilo que Carlos Novas (Novas \& Rose, 2000) sinalizou como sendo uma economia política de esperança, na qual se espera que a identificação de disfunções no nível genômico conduza à intervenção molecular e a uma vida melhor.

Muitas críticas também são feitas no sentido de que a biopolítica contemporânea, ao focar na 'vida em si', reduziria o indivíduo ao seu âmbito biológico, desconsiderando, ou mesmo eliminando, aspectos existenciais outros (Ortega, 2004; Castiel \& Álvarez-Dardet, 2007). Em tempos de uma saúde persecutória centrada na noção de risco, a responsabilização individual, reafirmada pelo discurso da promoção à saúde, impulsiona a busca desenfreada por uma saúde futura e por longevidade, por meio de vigilância e prevenção constantes na tentativa de tornar previsíveis as ameaças potenciais, mas que podem ter como consequência a limitação da vida humana aos aspectos somáticos (Castiel \& Álvarez-Dardet, 2007).

Entende-se que a modificação trazida pelo estilo de pensamento molecular, e que transcende um mero aprofundamento do olhar como o que ocorreu com o conhecimento anatomoclínico, promove uma reorganização na maneira de se compreender o ser humano, em seus corpos, identidades, pensamentos, vontades, desejos e comportamentos, em que o aspecto somático é relevante, mas não o único. As relações que o indivíduo estabelece consigo mesmo e com o mundo, a partir de novas formas de conhecimento de si, envolvem um intrincado tecido de relações e práticas definidoras de formas de governar indivíduos e grupos que não são redutíveis a uma visão biologizante ou genomizante. Essas novas relações são incorporadas, e novas verdades são produzidas.

É nesse sentido que a expressão de Ortega y Gasset (2007) é revisitada e adquire sentido como analogia, permitindo o delinear de novos percursos e a criação de novas imagens e elementos imaginativos mais adequados 
que possam traduzir o que hoje significa ser humano em suas mais variadas formas de viver.

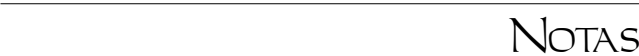

1 Interpretação dada por José Ortega y Gasset (2007) à vida humana individual e coletiva.

2 Em última instância, o autor refere-se à realidade espanhola com seus problemas e contradições.

3 Em reportagem no jornal O Globo, caderno Jornal da Família, em 27 out. 2002: a imagem de algo que se assemelha a um óvulo, num olhar microscópico, circundado por um meio aquoso que sugere uma expansão. A manchete diz: "Óvulo turbinado" (reafirmando a imagem); e o subtítulo complementa: "Novo tratamento médico que permite a gravidez tardia faz sucesso e causa polêmica entre os especialistas".

4 Por exemplo: "O doutor é animal: a zooterapia conquista credibilidade e ganha mais espaço no tratamento de uma série de distúrbios" (Veja, seção Saúde, em 30 nov. 2005).

5 Como na reportagem "Decifrado cromossomo 21 do homem: trabalho promete levar a tratamentos e testes para síndrome de Down e mal de Alzheimer" (O Globo, seção O Mundo/Ciência e Vida, em 9 maio 2000).

6 Como a metáfora do genoma humano como 'código' ou 'livro', por exemplo, em que as bases A, C, G e T são 'letras' e os cromossomos, 'fascículos' (O Globo, "Sequenciaram o genoma... E daí?", Primeiro Caderno, seção Opinião, em 31 jul. 2000).

7 Disponível em: <http://www.serdiferenteenormal.org.br>. Acesso em: 22 mar. 2009.

8 O Globo, "Outros olhos", Segundo Caderno, Coluna Gente Boa, 14 jun. 2007.

9 O Globo. "Lições de superação". Jornais de Bairro/Barra, 3 set. 2006.

10 Trechos extraídos de reportagem "Além dos limites", na Veja, seção Saúde, em 29 mar. 2000. Grifos meus.

11 O Globo, "Sequenciaram o genoma... E daí?", Primeiro Caderno, seção Opinião, em 31 jul. 2000 .

12 Os modelos animais são citados na Veja, "Estudo indica gene causador de Down", seção Ciência, em 6 jul. 2006; na reportagem "Síndrome de Down: origem em célulastronco, Notícias on-line, seção Ciência e Saúde, 5 set. 2008. Em O Globo, "DNA-lixo?, Primeiro Caderno, seção Opinião, em 22 maio 2002; "DNA de camundongo é 80\% igual ao humano", Primeiro Caderno, seção O Mundo/Ciência e Vida, em 5 dez. 2002. 
13 Veja, "O mapa do 21", seção Genética, em 17 maio 2000; O Globo, "Decifrando o cromossomo 21 do homem", Primeiro Caderno, seção O Mundo/Ciência e Vida, em 9 maio 2000.

14 O Globo, "Proteínas são o segredo da nova medicina", Primeiro Caderno, seção O Mundo/Ciência e Vida, em 23 jul. 2000. O estudo da estrutura e das funções das proteínas é feito por um campo da bioquímica, a proteômica (Nussbaum, McInnes \& Willard, 2002).

15 Veja, "A descoberta da molécula 'Down"', seção Ciência, em 6 dez. 2005. Disponível em: $<$ http://veja.abril.com.br/noticia/arquivo/descoberta-molecula-down>. Acesso em: 28 nov. 2006.

16 Veja, "Estudo indica gene causador de Down", seção Ciência, em 6 jul. 2006. Disponível em: <http://veja.abril.com.br/noticia/arquivo/estudo-indica-gene-causador-down>. Acesso em: 28 nov. 2006.

17 Um exemplo desse tipo de tecnologia encontra-se na reportagem sobre técnica de rejuvenescimento de óvulos, por meio da inclusão de uma pequena porção de citoplasma de uma doadora mais jovem. Uma forma de compensação para perdas decorrentes da idade - erros no processo de divisão celular - torna-se possível pela plasticidade e possibilidade de reprogramar as células e promover desenvolvimento adequado $(O$ Globo, "Óvulo turbinado", seção Jornal da Família, em 27 out. 2002).

18 Veja edição especial "O relógio biológico deles", A Melhor Idade, seção Família, em 31 ago. 2005 .

19 Veja, "Check-up", seção Especial, em 28 jun. 2000.

20 Friedrich Nietzsche (1996) reconta o mito de Pandora, salientando que a esperança ficou dentro da caixa enviada por Zeus aos homens para garantir que estes seriam atormentados por toda a vida. Assim, ele considera a esperança como o "pior dos males", por prolongar o sofrimento dos homens (Nietzsche, 1996: 45).

21 Veja, "Teste Genético para 140 milhões", seção Medicina, em 10 dez. 2008.

22 Contudo, nada é dito nas reportagens acerca das dúvidas que pairam em relação à melhor combinação de métodos a ser feita para rastreamento e diagnóstico da SD, como quais marcadores bioquímicos devem ser testados e como combiná-los, por exemplo (Kerr, 2004).

23 Trecho extraído do jornal O Globo, "Classe média gasta 10 mil com gravidez", seção Jornal da Família, em 28 mar. 2004.

24 Os dois trechos são extraídos de reportagem da Veja, "Retratos do bebê antes do parto", seção Guia Filho, em 18 set. 2002.

25 Citações retiradas de reportagem no jornal O Globo sobre técnica de rejuvenescimento de óvulos, já citada ("Óvulo turbinado", seção Jornal da Família, em 27 out. 2002). 
A técnica foi alvo de numerosas críticas e controvérsias pela escassez de informação sobre as consequências de transferência de DNA mitocondrial.

26 Por exemplo, a reportagem da Veja, "Exame pré-natal poderá acusar autismo", seção Ciência e Saúde, em 12 jan. 2009, sobre técnica desenvolvida na Inglaterra para detecção de casos de autismo, o que permitiria a escolha por parte dos pais de levar adiante a gestação, traz o questionamento do próprio pesquisador sobre a validade desse tipo de identificação pré-natal ao destacar os valores associados a essa condição, como talento e genialidade, em contraste com os associados à SD. Ou ainda na Veja, "A terrível escolha", seção Ética, em 16 mar. 2005, sobre eutanásia neonatal na Holanda em casos de doenças graves (uma delas, SD). 


\section{CODA OU UM SENTIDO DE FINALIZACC̃̃O...}

...There will be time, there will be time To prepare a face to meet the faces that you meet;

There will be time to murder and create, And time for all the works and days of hands That lift and drop a question on your plate; Time for you and time for me, And time yet for a hundred indecisions, And for a hundred visions and revisions, Before the taking of a toast and tea.

T. S. Eliot ("The love song of J. Alfred Prufrock", 1969: 14)

Quando uma história termina? Como se identifica o seu fim?

Na verdade, certas histórias não chegam a um fim propriamente dito, mas são constituídas de intervalos para retomada do fôlego, deixando entrever outros fios narrativos possíveis que partem do atual.

A história narrada aqui pertence a esse tipo, pois, seguindo a metáfora introduzida no início, outras vozes continuam e continuarão a cantar o tema principal escolhido como sujeito. Contudo, percebe-se uma pausa, mais longa do que as que ocorreram em outros momentos do percurso. Eé essa noção que faz com que se saiba que este é o momento de se criar um senso de finalização a tudo o que foi dito. É o tempo da 'coda' da fuga.

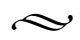


Conforme discutido, uma das características da biopolítica contemporânea é a preocupação com a capacidade crescente de modelar, controlar e administrar as características vitais dos seres humanos. Nesse processo, o que está em debate é a possibilidade de se redesenharem aspectos como metabolismo, órgãos, desenvolvimento, enfim, a própria vitalidade humana em escala molecular com fins de aprimoramento que extrapolam a moldura que demarca os extremos de saúde-doença. Diante disso, uma nova ética somática emerge, voltada para o futuro, mas solicitando ações no presente. Uma ética que precisa lidar com a inclusão dos processos vitais em economias da vitalidade e com as consequentes intervenções que se apresentam como possíveis e que se traduzem em modificações na concepção do 'eu'; uma ética que coloca em discussão significados relacionados a um tipo de cidadania, moldada cada vez mais por características biológicas específicas, que reúne os indivíduos em grupos que não os familiares, demandando escolhas, decisões e ações, as quais são negociadas nas práticas estabelecidas no âmbito da biomedicina.

Analisar as narrativas em SD significou focar uma dentre as muitas paisagens biológicas que se apresentam como possíveis na política da vida contemporânea. E ao fazê-lo, buscou-se olhar os eventos que a constituem em seus múltiplos processos, questionando o que se apresenta como autoevidente, com o intuito de compreender como os fenômenos são conhecidos e representados, de modo a neles intervir para transformá-los, e de distinguir a rede de relações e práticas que são levadas a cabo e que se traduzem em formas singulares de modelar e governar atitudes e comportamentos individuais e coletivos sem, contudo, negar a sua privacidade (Miller \& Rose, 2008a).

Trabalhar com narrativas escritas e iconográficas propiciou o contato com uma forma de pensar, nelas presente, que define as pessoas com SD como objetos da biopolítica, em termos tanto de seu vocabulário, retórica, conhecimento e moralidade quanto das tecnologias, entendidas como conjuntos de pessoas, técnicas, instituições e meios de governar condutas. É pela linguagem, considerada como uma 'tecnologia intelectual', que aspectos da realidade, como no caso a $\mathrm{SD}$, tornam-se adequados ao exercício 
do biopoder e suscetíveis a mecanismos de intervenção, não apenas como indivíduos mas como parte de uma população (Miller \& Rose, 2008b).

A ideia que é construída sobre os indivíduos com SD e que permeia as narrativas analisadas é interativa, isto é, qualquer classificação sobre pessoas interage com as próprias pessoas que são classificadas, principalmente porque classificações existem na materialidade das instituições, das práticas e das relações entre pessoas e coisas que compõem a matriz. As pessoas com SD assimilam aquilo que é pensado, conceitualizado e dito sobre elas exatamente por terem sido classificadas desse modo, modificando com isso a sua forma de existir no mundo, numa espécie de looping, que pode levar a mudanças na própria classificação. Por conseguinte, classificações são contingentes e explicitam a forma de pensar e agir de determinada época (Hacking, 2000). Este livro vasculhou uma época por meio do contato com diferentes fontes, da escuta de diferentes vozes, na intenção de apreender a ideia que se constrói sobre pessoas com SD e que se revela na pletora de imagens disseminadas nas narrativas.

Por meio de campanhas, livros, reportagens e eventos diversos, os pais de pessoas com SD tornam-se enfáticos militantes por melhor acesso a serviços educacionais e de saúde e pela inclusão social a fim de minimizar o estigma. As famílias se agregam em grupos maiores, construindo e compartilhando uma identidade calcada na condição biológica, e esses grupos estabelecem referências para si mesmos maciçamente moldadas por conceitos científicos/biomédicos. Tais grupos configuram comunidades, um novo território para administração da existência individual e coletiva, que podem ser delimitadas geograficamente como microespaços ou apenas conectadas no mundo virtual do ciberespaço, fazendo uso de discursos, símbolos, imagens, valores e crenças comuns que as identificam. Ainda que assemelhadas por se relacionarem a uma condição específica como a $\mathrm{SD}$, são heterogêneas e múltiplas, conformando-se como novas autoridades detentoras de um saber que é constituído como uma mistura de conhecimento científico e experiência, e criando novas relações de inclusão e exclusão (Rose, 2008). 
A presença da SD impele à construção de narrativas nas quais a jornada é um elemento comum que alude à metáfora da própria vida, como um grande caminho a ser percorrido no qual os percalços servem como aprendizados de superação, e se confunde com o caráter religioso que o sistema mitológico judaico-cristão a ela atribui. A possibilidade que essa mitologia oferece é a de considerar a 'impureza' de um corpo imperfeito como mola propulsora para a superação de si mesmo. Nas narrativas difundidas em livros, blogs e reportagens sobre inclusão, essa 'impureza' é paulatinamente negada como tal e reinterpretada como um 'aprimoramento genético' que, contudo, não resulta da ação humana, sendo visto ora através da naturalidade de uma carga gênica extra no cromossomo 21, ora como ação de uma instância divina. O que para a biopolítica contemporânea se configura como aprimoramento, pela possibilidade de intervenção tecnológica e como resultado de processos decisórios individuais, é absorvido e reinterpretado pelos grupos ligados à $\mathrm{SD}$, que se constituem como diferentes 'culturas', a fim de dar sentido a algo que é entendido e vivido como inexorável.

Subjacente à noção de aprimoramento, encontra-se a busca incessante por demonstrar capacidades e aptidões entre pessoas com SD e destas em relação às outras ditas 'normais', sinalizando o vigor de uma moldura que prega a sobrevivência do mais apto. Os parâmetros não são mais aqueles referentes a uma população territorializada que deve ser melhor que outra, numa configuração política de supremacia, mas localiza-se no indivíduo que deve tornar-se apto e demonstrar essa aptidão no enfrentamento com os outros, a fim de transformar aquilo que seria uma 'derrota' prenunciada pela deficiência em algo transcendente às falhas e aos limites do próprio humano.

Textos e imagens disseminados em campanhas institucionais, filmes, livros, blogs e reportagens sobre inclusão configuram-se como estratégias para unificar não apenas uma experiência percebida inicialmente como fragmentadora, mas também um self que se revela múltiplo e que expõe de forma clara a inadequação de um modelo de pensar o ser humano em sua diferença, com capacidades, habilidades e limitações, lançando 
mão de discursos que resultam ambíguos. As reportagens na área da genômica e das tecnologias reprodutivas também transitam em ambiguidade, destacando meios cada vez mais precisos para escolhas circunstanciais autônomas sem, todavia, abrir terreno para uma ampla discussão sobre os múltiplos aspectos que estas envolvem.

O movimento de tentativa de unificação, apesar de ser resultado da quebra de um padrão já esgotado, pouco oferece como alternativa de ressignificação. As metáforas às quais alude equivalem aos fenômenos ópticos de reflexão e refração que produzem imagens do 'mesmo', ainda que deslocado ou distorcido; um 'mesmo' que corresponde ao ideal iluminista de ser humano autônomo e capaz e que segue orientando a definição de pessoa. A promessa de igualdade por meio da razão fracassa na presença da SD; entretanto, o padrão não logra ser modificado. O cérebro-razão persiste como o aspecto principal e mais valorizado do humano a determinar o alicerce da identidade de uma pessoa.

O fenômeno da difração oriundo da geometria e da óptica oferece uma metáfora alternativa para pensar as relações de diferença entre pessoas, sejam elas com SD ou não. A difração não produz a imagem do 'mesmo', como o fazem a reflexão e a refração. Em ambas, o objeto mantém-se íntegro em sua identidade original. Na difração, as ondas são decompostas ao sofrerem uma interferência, ocasionando uma mudança irreversível que gera novos e múltiplos padrões, os quais não podem ser referendados ao padrão anterior. Dito de outra forma, a difração não mostra a origem das diferenças, mas os efeitos delas, tornando necessário um olhar mais sutil sobre o que se analisa (Haraway, 1992). Assim, a presença da SD traduz-se numa interferência que modifica o padrão de forma definitiva, tornando inadequada qualquer tentativa de referência ao padrão original prévio. A aparente afirmação da diferença indiciariamente sugere a sua paradoxal eliminação ao tentar utilizar como referência o mesmo padrão esgotado.

Na perspectiva da política da 'vida em si', como na difração, a ênfase não está na origem da diferença - por exemplo, na busca por eliminar condições de doença ameaçadoras para uma população -, mas na possibi- 
lidade de alterar padrões vitais antes tidos como imutáveis, que irão resultar em novas configurações não mais restritas a uma moldura de normatividade. A importância é, então, dada aos efeitos resultantes dessas alterações, com destaque para a responsabilidade solicitada a cada indivíduo em relação à sua história individual e familiar e à forma como se pensa e se relaciona consigo mesmo em sua existência corpórea, por meio de novos jogos de verdade que conformam o que Rose (2007) denomina como 'ethopolítica', na qual novas formas de autoridade podem e são exercidas.

A definição de uma cidadania biológica, como no caso da SD, pode tomar diferentes aspectos segundo as diferentes comunidades - localizadas ou não numa coletividade maior como nação ou sociedade -, os laços de identificação, obrigação e responsabilidade decorrentes do pertencimento a elas e as condições mais ou menos propícias para o exercício de ativismo em busca de direitos a melhores condições de vida. Entretanto, algo comum perpassa as histórias, os discursos, as imagens, uma forma compartilhada dos indivíduos de se relacionarem consigo mesmos e com seu familiar com SD, renomeando, modelando e acomodando significados e sentimentos de medo, rejeição e esperança para criar novas e possíveis circunstâncias de vida diante de um futuro que se apresenta velado, por se mostrar aberto a novas possibilidades e configurações, em que a escolha tornar-se-á inevitável e o principal elemento em questão é a 'vida em si', ou as diferentes formas de ser humano.

NOTA

1 "...Haverá tempo, haverá tempo / Para compor um rosto para encontrar os rostos que encontrares; / Haverá tempo para matar e criar, / E tempo para todos os trabalhos e os dias de mãos que se erguem sobre o teu prato e deixam cair uma pergunta; / Tempo para ti e tempo para mim, / E tempo ainda para uma centena de indecisões, / E para uma centena de visões e revisões, / Antes de tomar o chá com torradas" (Tradução livre). 


\section{REFERÊNCIAS}

AFTERLIFE [filme]. UK: Soda Pictures, 2005.

AGAMBEN, G. Homo Sacer: sovereign power and bare life. Stanford: Stanford University Press, 1998.

ALLEN, G. et al. Mongolism. The Lancet, 277: 775, 1961.

AMIGONI, D. What is special about the gene? A literary perspective. Genomics, Society and Policy, 4(1): 1-11, 2008. Disponível em: <www.gspjournal.com>. Acesso em: 22 jan. 2009.

BADGER, M. Visual blogs. In: GURAK, L. J. et al. (Eds.) Into the Blogosphere: rhetoric, community, and culture of weblogs. Minneapolis: University of Minnesota, 2004. Disponível em: <blog.lib.umn.edu/blogosphere/ visual_blogs.html>. Acesso em: 17 dez. 2008.

BAKHTIN, M. Rabelais and His World. Bloomington: Indiana University Press, 1984.

BALANDIER, G. O Dédalo: para finalizar o século XX. Rio de Janeiro: Bertrand Brasil, 1999.

BARTHES, R. Image - Music - Text. London: Fontana Press, 1977.

BARTHES, R. Mitologias. Rio de Janeiro: Bertrand Brasil, 2001.

BARTHES, R. Elementos de Semiologia. São Paulo: Cultrix, 2003.

BENDA, C. E. Mongolism or Down's syndrome. The Lancet, 279: 163, 1962. 
BERG, J. M. \& KOROSSY, M. Down syndrome before Down: a retrospect. American Journal of Medical Genetics, 102: 205-211, 2001.

BIGNELL, J. Media Semiotics: an introduction. Manchester: Manchester University Press, 2002.

BLANCHARD, A. Blogs as virtual communities: identifying a sense of community in the Julie/Julia Project. In: GURAK, L. J. et al. (Eds.) Into the Blogosphere: rhetoric, community, and culture of weblogs. Minneapolis: University of Minnesota, 2004. Disponível em: <blog.lib.umn.edu/ blogosphere/blogs_as_virtual.html >. Acesso em: 11 ago. 2008.

BLANCHOT, M. The Space of Literature. Nebraska: University of Nebraska Press, 1990.

BRASIL. Secretaria de Educação Especial. Programa de Educação Inclusiva: direito à diversidade - a fundamentação filosófica. Brasília: Ministério da Saúde, 2004.

BRASIL. Secretaria de Atenção à Saúde. Política Nacional de Saúde da Pessoa Portadora de Deficiência. Brasília: Ministério da Saúde, 2008. (Série E - Legislação em Saúde).

BRATTON, B. H. A premissa da arquitetura recombinante. Rizoma.net, 2002. Disponível em: <www.rizoma.netinterna.php?id=151\&secao=anarquitex tura $>$. Acesso em: 11 mar. 2007.

BRECHMAN, J.; LEE, C. \& CAPPELLA, J. N. Lost in translation? A comparison of cancer-genetics reporting in the press release and its subsequent coverage in the press. Science Communication, 30(4): 453-474, 2009.

BURCHELL, K.; FRANKLIN, S. \& HOLDEN, K. Public Culture as Professional Science: final report of the ScoPE project - scientists on public engagement: from communication to deliberation? London: Bios, London School of Economics and Political Science, 2009.

BURRI, R. V. \& DUMIT, J. (Eds.) Introduction. In: BURRI, R. V. \& DUMIT, J. (Eds.) Biomedicine as Culture: instrumental practices, technoscientific knowledge, and new modes of life. New York: Routledge, 2007. 
CAIRO, S. Our Brother Has Down's Syndrome: an introduction for children. Toronto, New York, Vancouver: Annick Press, 1999.

CALVINO, I. Seis Propostas para o Próximo Milênio. São Paulo: Companhia das Letras, 1990.

CANGUILHEM, G. O Normal e o Patológico. Rio de Janeiro: Forense Universitária, 2002.

CAPONE, G. T. Down syndrome: advances in molecular biology and the neurosciences. Journal of Developmental \& Behavioral Pediatrics, 22: 40-59, 2001. Disponível em: <www.jrnldbp.com/pt/re/jdbppdfhandler. $00004703-200102000-00007$. pdf; jsessionid = FGH JYd qpDQn 70 n 8 WS 5 PS PxMbnhL 3 H 26 r Gl O RWy 4 vhvl 7 Y f m QL $8 \mathrm{w}$ ! - 1946698971 ! - 949856145 ! 8091 ! 1 ? index $=1 \&$ database $=$ ppvovft $\&$ results $=1 \&$ count $=10 \&$ searchid $=$ $3 \&$ nav $=$ search $>$. Acesso em: 14 dez. 2006.

CARATZALI, A. Mongolism. The Lancet, 277: 1.116-1.117, 1961.

CARDOSO, C. F. Narrativa, Sentido, História. Campinas: Papirus, 1997.

CARDOSO, M. H. C. A. A Herança Arcaica de um Modelo: história, medicina... e a síndrome de Down, 2000. Tese de Doutorado, Rio de Janeiro: Instituto Nacional de Saúde da Mulher, da Criança e do Adolescente Fernandes Figueira, Fundação Oswaldo Cruz.

CARDOSO, M. H. C. A. Uma produção de significados sobre síndrome de Down. Cadernos de Saúde Pública, 19(1): 101-109, 2003.

CASTIEL, L. D. Moléculas, Moléstias, Metáforas: o senso dos humores. São Paulo: Unimarco, 1996.

CASTIEL, L. D. A Medida do Possível... saúde, risco e tecnobiociências. Rio de Janeiro: Contracapa, Editora Fiocruz, 1999.

CASTIEL, L. D. Promoção de saúde e a sensibilidade epistemológica da categoria 'comunidade'. Revista de Saúde Pública, 38(5): 615-622, 2004. CASTIEL, L. D. \& ÁlVAREZ-DARDET, C. D. A Saúde Persecutória: os limites da responsabilidade. Rio de Janeiro: Editora Fiocruz, 2007. 
CASTIEL, L. D. \& VASCONCELLOS-SILVA, P. R. Precariedades do Excesso: informação e comunicação em saúde coletiva. Rio de Janeiro: Editora Fiocruz, 2006. CASTORIADIS, C. A Instituição Imaginária da Sociedade. São Paulo: Paz e Terra, 2000.

CHANDLER, D. Semiotics: the basics. Abingdon: Routledge, 2007.

COLLIER, J.; ROSALDO, M. Z. \& YANAGISAKO, S. Is there family? New anthropological views. In: LANCASTER, R. N. \& Di LEONARDO, M. (Eds.) The Gender Sexuality Reader. New York, London: Routledge, 1997.

COPEMAN, J. Gathering points: blood donation and the scenography of 'national integration' in India. Body \& Society, 15(2): 71-99, 2009.

CRISSMAN, B. G. et al. Current perspectives on Down syndrome: selected medical and social issues - introduction. American Journal of Medical Genetics Part C (Seminars in Medical Genetics), 142C: 127-130, 2006.

CULLEY, L. \& HUDSON, N. Constructing relatedness: ethnicity, gender and third party assisted conception in the UK. Current Sociology, 57(2): 249-267, 2009.

CUNNINGHAM, C. Understanding Down Syndrome: an introduction for parents. Cambridge: Brookline Books, 1996.

CYRENO, L. Meu Rei Arthur: a chegada de um filho com síndrome de Down. São Paulo: Paulinas, 2007a. (Coleção Fé e Vida)

CYRENO, L. O Pequeno Rei Arthur: convivendo com a síndrome de Down. São Paulo: Paulinas, 2007b.

DAVIS, L. J. Nude Venuses, Medusa's body, and phantom limbs: disability and visuality. In: MITCHELL, D. T. \& SNYDER, S. L. (Eds.) The Body and Physical Difference. Ann Arbor: University of Michigan Press, 1997.

DEAN, M. Risk, calculable and incalculable. In: LUPTON, D. (Ed.) Risk and Sociocultural Theory: new directions and perspectives. Cambridge: Cambridge University Press, 1999.

DELEUZE, G. Postscript on control societies. October, 59: 3-7, 1992. 
DILLON, M. \& LOBO-GUERRERO, L. The biopolitical imaginary of speciesbeing. Theory, Culture \& Society, 26(1): 1-23, 2009.

DO LUTO À LUTA [filme]. São Paulo: Casa Azul Produções Artísticas e Circuito Espaço de Cinema, 2004.

DOWN, J. L. H. Observations on an ethnic classification of idiots. London Hospital Reports, 3: 259-262, 1866. Disponível em: <www.neonatology.org/ classics/down.html>. Acesso em: 25 ago. 2009.

DUDEN, B. \& SAMERSKI, S. 'Pop genes': an investigation of 'the gene' in popular parlance. In: BURRI, R. V. \& DUMIT, J. (Eds.) Biomedicine as Culture: instrumental practices, technoscientific knowledge, and new modes of life. New York: Routledge, 2007.

DUMIT, J. A digital image of the category of the person: PET scanning and objective self-fashioning. In: DOWNEY, G. L. \& DUMIT, J. (Eds.) Cyborgs \& Citadels: anthropological interventions in emerging sciences and technologies. Santa Fe: School of American Research Advanced Series, 1997.

DUNN, C. W. Mongolism. The Lancet, 277: 1.116, 1961.

DUNN, P. M. Perinatal lessons from the past: dr. Langdon Down (1828-1896) and 'mongolism'. Archives of Disease in Childhood, 66: 827-828, 1991.

ECO, U. A Theory of Semiotics. Bloomington: Indiana University Press, 1979. ELIOT, T. S. The Complete Poems and Plays. London: Faber and Faber, 1969. EMSLIE, C.; HUNT, K. \& WATT, G. A chip off the old block? Lay understandings of inheritance among men and women in mid-life. Public Understanding of Science, 12(1): 47-65, 2003.

EPSTEIN, J. Defining disease. In: EPSTEIN, J. Altered Conditions: disease, medicine, and storytelling. London: Routledge, 1995.

FARAWAY, SO CLOSE! [filme]. Germany: Sony Pictures Classics, 1993.

FELT, U. et al. Refusing the information paradigm: informed consent, medical research, and patient participation. Health (London), 13(1): 87106, 2009. 
FENNELL, D. Marketing science: the corporate faces of genetic engineering. Journal of Communication Inquiry, 33(1): 5-26, 2009.

FLECK, L. Genesis and Development of a Scientific Fact. Chicago: The University of Chicago Press, 1981.

FONSECA, C. T. et al. Insulin resistance in adolescents with Down syndrome: a cross-sectional study. BMC Endocrine Disorders, 5: 6, 2005. Disponível em: $<$ www.biomedcentral.com/1472-6823/5/6>. Acesso em: 26 set. 2005.

FOUCAULT, M. This is not a Pipe. Berkeley, Los Angeles: University of California Press, 1983.

FOUCAUlT, M. As Palavras e as Coisas. São Paulo: Martins Fontes, 2002.

FOUCAULT, M. Technologies of the self. In: RABINOW, P. \& ROSE, N. (Eds.) The Essential Foucault: selection from Essential Works of Foucault, 1954-1984. New York: The New Press, 2003a.

FOUCAULT, M. História da Sexualidade 1: a vontade de saber. Rio de Janeiro: Graal, 2003b.

FOUCAULT, M. Omnes et singulatim: toward a critique of political reason. In: RABINOW, P. \& ROSE, N. (Eds.) The Essential Foucault: selection from essential works of Foucault, 1954-1984. New York: The New Press, 2003c.

FOUCAULT, M. Governmentality. In: RABINOW, P. \& ROSE, N. (Eds.) The Essential Foucault: selection from essential works of Foucault, 1954-1984. New York: The New Press, 2003d.

FOUCAULT, M. História da Sexualidade 2: o uso dos prazeres. Rio de Janeiro: Edições Graal, 2006.

FRANKLIN, S. Embodied Progress: a cultural account of assisted conception. Abingdon: Routledge, 1997.

FRANKLIN, S. Life itself: global nature and the genetic imaginary. In: FRANKLIN, S.; LURY, C. \& STACEY, J. (Eds.) Global Nature, Global Culture. London: Sage, 2000. 
FRANKLIN, S. Stem cell $\mathrm{r}$ us: emergents life forms and the global biological. In: ONG, A. \& COLLIER, S. J. (Eds.) Global Assemblages: technology, politics, and ethics as anthropological problems. Oxford: Blackwell Publishing, 2005. FRANKLIN, S. Dolly Mixtures: the remaking of genealogy. Durham, London: Duke University Press, 2007.

FRANKLIN, S. \& ROBERTS, C. Born and Made: an ethnography of preimplantation genetic diagnosis. Princeton: Princeton University Press, 2006.

FRANKLIN, S.; LURY, C. \& STACEY, J. Introduction. In: FRANKLIN, S.; LURY, C. \& STACEY, J. (Eds.) Global Nature, Global Culture. London: Sage, 2000. GARCÍA MÁRQUEZ, G. Vivir para Contarla. Nueva York: Vintage Español, Random House, 2003.

GARDINER, K. \& COSTA, A. C. S. The proteins of human chromosome 21. American Journal of Medical Genetics Part C (Seminars in Medical Genetics), 142C: 196-205, 2006.

GATTACA [filme]. USA: Columbia Pictures Corporation, 1997.

GINZBURG, C. Sinais: raízes de um paradigma indiciário. In: GINZBURG, C. Mitos, Emblemas, Sinais: morfologia e história. São Paulo: Companhia das Letras, 2001a.

GINZBURG, C. Olhos de Madeira: nove reflexões sobre a distância. São Paulo: Companhia das Letras, 2001b.

GINZBURG, C. O Queijo e os Vermes: o cotidiano e as ideias de um moleiro perseguido pela Inquisição. São Paulo: Companhia das Letras, 2002.

GINZBURG, C. Chaves do mistério: Morelli, Freud e Sherlock Holmes. In: ECO, H. \& SEBEOK, T. (Orgs.) O Signo de Três. São Paulo: Perspectiva, 2004.

GRAY, C. Narratives of disability and the movement from deficiency to difference. Cultural Sociology, 3(2): 317-332, 2009.

GREIMAS, A. J. On Meaning: selected writings in semiotic theory. Minneapolis: University of Minnesota Press, 1987.

GRONEBERG, J. G. Road Map to Holland: how I found my way through my son's first two years with Down syndrome. New York: New American Library, 2008. 
HACKING, I. The argument. In: HACKING, I. The Taming of Chance. Cambridge: Cambridge University Press, 1990.

HACKING, I. The Social Construction of What? Cambridge: Harvard University Press, 2000.

HACKING, I. The Cartesian vision fulfilled: analogue bodies and digital minds. Interdisciplinary Science Reviews, 30(2): 153-166, 2005.

HACKING, I. Genetics, biosocial groups \& the future of identity. Daedalus, 135(4): 81-95, 2006.

HACKING, I. Our neo-Cartesian bodies in parts. Critical Inquiry, 34: 78$105,2007$.

HARAWAY, D. J. Simians, Cyborgs, and Women: the reinvention of nature. New York: Routledge, 1991.

HARAWAY, D. J. The promise of monsters: a regenerative politics for inappropriate/d others. In: GROSSBERG, L.; NELSON, C. \& TREICHLER, P. A. (Eds.) Cultural Studies. London: Routledge, 1992.

HARAWAY, D. J. Pragmatics: technoscience in hypertext. In: HARAWAY, D.J.Modest_Witness@Second_Millenium.FemaleMan@__Meets_Onco Mouse $^{\mathrm{TM}}$. Feminism and Technoscience. New York: Routledge, 1997. HAVE YOU HAD A GENE TEST? [Editorial]. The Lancet, 347: 133, 1996. HAWKINS, A. H. Reconstructing Illness: studies in pathography. Indiana: Purdue University Press, 1999.

HENDERSON, J. L. Os mitos antigos e o homem moderno. In: JUNG, C. G. (Org.) O Homem e seus Símbolos. Rio de Janeiro: Nova Fronteira, 1996.

HILlmAN, J. Psicologia Arquetípica. São Paulo: Cultrix, 1992.

HILLMAN, J. The virtues of caution. Resurgence, 213, 2002. Disponível em: <www.resurgence.org/resurgence/issues/hillman213.htm>. Acesso em: 17 jul. 2007.

HIMMER, S. The labyrinth unbound: weblogs as literature. In: GURAK, L. J. et al. (Eds.) Into the Blogosphere: rhetoric, community, and culture of weblogs. Minneapolis: University of Minnesota, 2004. Disponível em: 
<blog.lib.umn.edu/blogosphere/labyrinth_unbound.html>. Acesso em: 24 nov. 2008.

HOLLMAN, A. Down's syndrome (Mongolism). The Lancet, 278: 1.146, 1961. HOUAISS, A.; VILLAR, M. S. \& MELLO FRANCO, F. M. Dicionário Houaiss da Língua Portuguesa. Rio de Janeiro: Objetiva, 2004.

HOWARD-JONES, N. On the diagnostic term 'Down's disease'. Medical History, 23: 102-104, 1979.

JOYCE, K. Appealing images: magnetic resonance imaging and the production of authoritative knowledge. Social Studies of Science, 35(3): 437462, 2005.

JUNG, C. G. Os Arquétipos e o Inconsciente Coletivo. Petrópolis: Vozes, 2000. KATO, M. No Mundo da Escrita: uma perspectiva psicolingüística. São Paulo: Ática, 1986.

KAY, L. E. Who Wrote the Book of Life? A history of the genetic code. Stanford: Stanford University Press, 2000.

KELLER, E. F. The gender/science system: or, is sex to gender as nature is to science? In: BIAGIOLI, M. (Ed.) The Science Studies Reader. New York: Routledge, 1999.

KELLER, E. F. The Century of the Gene. Cambridge: Harvard University Press, 2000 .

KELLER, E. F. Making Sense of Life: explaining biological development with models, metaphors, and machines. Cambridge: Harvard University Press, 2003.

KENNEDY, M. \& KENNEDY, J. (Eds.) The Concise Oxford Dictionary of Music. Oxford: Oxford University Press, 2007.

KERR, A. Genetics and Society: a sociology of disease. London: Routledge, 2004. KIDDER, C. S. \& SKOTKO, B. Common Threads: celebrating life with Down syndrome. Michigan: Band of Angels, 2007.

KIRBY, D. The future is now: diegetic prototypes and the role of popular films in generating real-world technological development. Social Studies of 
Science OnlineFirst, 2009. Disponível em: <http://sss.sagepub.com/cgi/ content/abstract/0306312709338325v1 >. Acesso em: 6 nov. 2009.

KLEIN, S. D. \& SCHIVE, K. You Will Dream New Dreams: inspiring personal stories by parents of children with disabilities. New York: Kensington Books, 2001.

KNUDSEN, S. Communicating novel and conventional scientific metaphors: a study of the development of the metaphor of genetic code. Public Understanding of Science, 14(4): 373-392, 2005.

KÜBLER-ROSS, E. Sobre a Morte e o Morrer. São Paulo: Martins Fontes, 1985. LACAN, J. The mirror stage as formative of the function of the I as revealed in psychoanalytic experience. In: LACAN, J. Écrits: the first complete edition in English. New York: W. W. Norton \& Co., 2007.

LAW \& ORDER: SPECIAL VICTIMS UNIT [Série de televisão]. Third season, episode 22. USA: Universal Studios, 2002.

LEJEUNE, J.; GAUTIER, M. \& TURPIN, R. The chromosomes of man. The Lancet, 273: 885-886, 1959.

LEMKE, T. Susceptible individuals and risky rights. In: BURRI, R. V. \& DUMIT, J. (Eds.) Biomedicine as Culture: instrumental practices, technoscientific knowledge, and new modes of life. New York, London: Routledge, 2007.

LENNOX, B. Down's syndrome (Mongolism). The Lancet, 278: 1.093, 1961. LENTZOS, F. \& ROSE, N. Governing insecurity: contingency planning, protection, resilience. Economy and Society, 38(2): 230-254, 2009.

LEVY, T. S. A Experiência do Fora: Blanchot, Foucault e Deleuze. Rio de Janeiro: Relume Dumará, 2003.

LOCK, M. Eclipse of the gene and the return of divination. Current Anthropology, 46, supl.: 547-570, 2005.

LOS ABRAZOS ROTOS [filme]. España: El Deseo S.A., 2009.

LUPTON, D. Risk and the ontology of pregnant embodiment. In: LUPTON, D. (Ed.) Risk and Sociocultural Theory: new directions and perspectives. Cambridge: Cambridge University Press, 1999. 
LYNCH, J. Stem cells and the embryo: biorhetoric and scientism in Congressional debate. Public Understanding of Science, 18(3): 309-324, 2009. MANCA, J. Andrea Mantegna and the Italian Renaissance. New York: Parkstone Press International, 2006.

MARÍLIA GABRIELA ENTREVISTA [programa de televisão]. São Paulo: GNT/ Globosat, 27 nov. 2005.

MILLER, C. R. \& SHEPHERD, D. Blogging as social action: a genre analysis of the weblog. In: GURAK, L. J. et al. (Eds.) Into the Blogosphere: rhetoric, community, and culture of weblogs. Minneapolis: University of Minnesota, 2004. Disponível em: <blog.lib.umn.edu/blogosphere/ blogging_as_social_action_a_genre_analysis_of_the_weblog.html >. Acesso em: 3 dez. 2008.

MILLER, F. A. Dermatoglyphics and the persistence of 'mongolism'. Social Studies of Science, 33(1): 75-94, 2003.

MILLER, P. \& ROSE, N. Introduction: governing economic and social life. In: MILLER, P. \& ROSE, N. Governing the Present: administering economic, social and personal life. Cambridge: Polity Press, 2008a.

MILLER, P. \& ROSE, N. Governing economic life. In: MILLER, P. \& ROSE, N. Governing the Present: administering economic, social and personal life. Cambridge: Polity Press, 2008b.

MOORE-MALlinos, J. Mi Amiga Tiene el Síndrome de Down. New York: Barron's Educational Series, 2008.

MORGAN, M. \& THOMAS, M. Lay and professional constructions of time: implications for illness behaviour and management of a chronic condition. Sociology, 43(3): 555-572, 2009.

NELKIN, D. God talk: confusion between science and religion - posthumous essay. Science, Technology \& Human Values, 29(2): 139-152, 2004.

NELKIN, D. \& LINDEE, M. S. The DNA Mystique: the gene as a cultural icon. Michigan: The University of Michigan Press, 2004.

NIETZSCHE, F. On the history of the moral sensations. In: NIETZSCHE, F. Human, All Too Human. Cambridge: Cambridge University Press, 1996. 
NOLL, J. G. Mínimos, Múltiplos, Comuns. São Paulo: Francis, 2003.

NOVAS, C. \& ROSE, N. Genetic risk and the birth of the somatic individual. Economy and Society, 29(4): 485-513, 2000.

NUSSBAUM, R. L.; McINNES, R. R. \& WILLARD, H. F. Thompson \& Thompson: genética médica. Rio de Janeiro: Guanabara Koogan, 2002.

O GLOBO. Decifrado o cromossomo 21 do homem. O Globo, Rio de Janeiro, 9 maio 2000. Primeiro Caderno, O Mundo/Ciência e Vida, p. 32.

O GLOBO. AZEVEDO, A. L. Proteínas são segredo da nova medicina. O Globo, Rio de Janeiro, 23 jul. 2000. Primeiro Caderno, O Mundo/Ciência e Vida, p. 40.

O GLOBO. PEREIRA, L. V. Sequenciaram o genoma... E daí? O Globo, Rio de Janeiro, 31 jul 2000. Primeiro Caderno, Opinião, p. 7.

O GLOBO. GARCIA, E. S. DNA-lixo? O Globo, Rio de Janeiro, 22 maio 2002. Primeiro Caderno, Opinião, p. 7.

O GLOBO. INTRATOR, S. Óvulo turbinado. O Globo, Rio de Janeiro, 27 out. 2002. Jornal da Família, p. 1-2.

O GLOBO. DNA de camundongo é 80\% igual ao humano. O Globo, Rio de Janeiro, 5 dez. 2002. Primeiro Caderno, O Mundo/Ciência e Vida, p. 39.

O GLOBO. CEZIMBRA, M. Classe média gasta R\$ 10 mil com gravidez. O Globo, Rio de Janeiro, 28 mar. 2004. Jornal da Família, p. 3.

O GLOBO. NETO, L. Lições de superação. O Globo, Rio de Janeiro, 3 set. 2006. Jornais de Bairro/Barra.

O GLOBO. SANTOS, J. F. Outros olhos. O Globo, Rio de Janeiro, 14 jun. 2007. Segundo Caderno, Coluna Gente Boa, p. 3.

O'RIORDAN, K. \& HARAN, J. From reproduction to research: sourcing eggs, IVF and cloning in the UK. Feminist Theory, 10(2): 191-210, 2009.

ORTEGA, F. Biopolíticas da saúde: reflexões a partir de Michel Foucault, Agnes Heller e Hannah Arendt. Interface - Comunicação, Saúde, Educação, 8(14): 9-20, 2004. 
ORTEGA, F. O corpo transparente: visualização médica e cultura popular no século XX. História, Ciências, Saúde - Manguinhos, 13, supl.: 89-107, 2006.

ORTEGA Y GASSET, J. Meditaciones del Quijote. Madrid: Ediciones Cátedra, 2007.

PÁGINAS DA VIDA [novela]. Rio de Janeiro: Rede Globo de Televisão, 20062007.

PALMER, J. Seeing and knowing: ultrasound images in the contemporary abortion debate. Feminist Theory, 10(2): 173-189, 2009.

PEIRCE, C. S. Divisão dos signos. In: PEIRCE, C. S. Semiótica. São Paulo: Perspectiva, 2003.

PESSOA, F. Obras Completas: odes de Ricardo Reis. Lisboa: Edições Ática, 1994. PESSOA, F. Quaresma, Decifrador: as novelas policiárias. Lisboa: Assírio \& Alvim, 2008.

PITZER, M. W. I Can, Can You? Bethesda: Woodbine House, 2004.

PUESCHEL, S. M. Panorama histórico. In: PUESCHEL, S. M. Síndrome de Down: guia para pais e educadores. São Paulo: Papirus, 2005.

RABE, B. Where's Chimpy? Illinois: Albert Whitman \& Company, 1988.

RABINOW, P. Artificiality and enlightenment: from sociobiology to biosociality. In: CRARY, J. \& KWINTER, S. (Eds.) Incorporations. New York: Zone Books, 1992.

RABINOW, P. \& ROSE, N. Biopower today. BioSocieties, 1: 195-217, 2006. RAMSDEN, E. Confronting the stigma of eugenics: genetics, demography and the problems of population. Social Studies of Science, 39(6): 853-884, 2009.

RAPP, R. Testing Women, Testing the Fetus: the social impact of amniocentesis in America. New York: Routledge, 2000.

RHEINBERGER, H.-J. Beyond nature and culture. In: LOCK, M.; YOUNG, A. \& CAMBROSIO, A. (Eds.) Living and Working with New Medical Technologies: intersections of inquiry. Cambridge: Cambridge University Press, 2000. 
ROOF, J. R. The Poetics of DNA. Minneapolis: University of Minnesota Press, 2007. ROSE, N. The Politics of Life Itself: biomedicine, power, and subjectivity in the twenty-first century. Princeton: Princeton University Press, 2007.

ROSE, N. The death of the social? Re-figuring the territory of government. In: MILLER, P. \& ROSE, N. (Eds.) Governing the Present: administering economic, social and personal life. Cambridge: Polity Press, 2008.

SAINT AUGUSTINE. City of God. London: Penguin Books, 2003.

SAMPSON, J. Down (Syndrome) but not Out: a journey from grief to joy. Washington: Pleasant Word, WinePress Publishing, 2007.

SARAMAGO, J. Cadernos de Lanzarote. São Paulo: Companhia das Letras, 1998. SARAMAGO, J. Ensaio sobre a Lucidez. São Paulo: Companhia das Letras, 2004.

SAUSSURE, F. Course in general linguistics. In: BALLY, C. \& SECHEHAYE, A. (Eds.) Course in General Linguistics. London: Duckworth, 1983.

SCHAAP, F. Links, lives, logs: presentation in the Dutch blogosphere. In: GURAK, L. J. et al. (Eds.) Into the Blogosphere: rhetoric, community, and culture of weblogs. Minneapolis: University of Minnesota, 2004. Disponível em: <blog.lib.umn.edu/blogosphere/links_lives_logs.html>. Acesso em: 11 ago. 2008.

SCHWARTZMAN, J. S. (Org.) Síndrome de Down. São Paulo: Mackenzie, Memnon, 1999.

SELIKOWITZ, M. Down Syndrome: the facts. New York: Oxford University Press, 1997.

SOARES, M. Letramento e alfabetização: as muitas facetas, 2003. Disponível em: <www.anped.org.br/26/outrostextos/semagdasoares.doc>. Acesso em: 12 jun. 2006.

SOPER, K. L. (Ed.) Gifts: mothers reflect on how children with Down syndrome enrich their lives. Bethesda: Woodbine House, 2007.

SPALDING, J. M. K. Down's syndrome (Mongolism). The Lancet, 278: 1.093$1.094,1961$. 
STRATFORD, B. Down's syndrome at the Court of Mantua. Maternal and Child Health, 7: 250-254, 1982.

STRATFORD, B. In the beginning. In: STRATFORD, B. \& GUNN, P. (Eds.) New Approaches to Down Syndrome. New York: Cassel, 1996.

STUVE-BODEEN, S. We'll Paint the Octopus Red. Bethesda: Woodbine House, 1998. TELEGRAPH. EDEN, R. Penélope Cruz is sure to be watched closely by Daniel Day-Lewis, 18 abr. 2009. Disponível em: <www.telegraph.co.uk/ news/newstopics/mandrake/5178450/Penlope-Cruz-is-sure-to-bewatched-closely-by-Daniel-Day-Lewis.html>. Acesso em: 15 set. 2009. TERRY, S. F. \& BOYD, C. D. Researching the biology of PXE: partnering in the process. American Journal of Medical Genetics, Seminars in Medical Genetics, 106(3): 177-184, 2001.

TERRY, S. F. et al. Advocacy groups as research organizations: the PXE International example. Nature Reviews Genetics, 8: 157-164, 2007.

TEZZA, C. O Filho Eterno. Rio de Janeiro: Record, 2007.

TFOUNI, L. V. Adultos Não Alfabetizados: o avesso do avesso. São Paulo: Pontes, 1988 .

THACKER, E. The Global Genome: biotechnology, politics, and culture. Cambridge: MIT Press, 2006.

UNITED STATES OF AMERICA. The Adoption Assistance and Child Welfare Act of 1980. P.L. 96-272. 96th Congress, 1980. Disponível em: <http:// www.childwelfare.gov/systemwide/laws_policies/federal/ index.cfm? event $=$ federalLegislation. viewLegis\&id $=22>$. Acesso $\mathrm{em}$ : nov. 2008-mar.2009.

THE SEVENTH SIGN [filme]. USA: Interscope Communications, 1988.

THE SUNDAY TIMES. GALLAGHER, P. Irish couples use gender selection. Disponível em: <http://Www.thesundaytimes.co.uk/sto/news/ world_news/article154757.ece>. Acesso em: 8 mar. 2009.

THE TIMES. HENDERSON, M. Doctor, I've got a problem with my genome... $<$ www.timesonline.co.uk/tol/comment/columnists/guest_contributors/ article6087900.ece>. Acesso em: 14 abr. 2009 (Link desativado) 
TODOROV, T. Structural analysis of narrative. Novel, 3: 70-76, 1969. TUNES, E. \& PIANTINO, L. D. Cadê a Síndrome de Down que Estava Aqui? O Gato comeu...: o programa da Lurdinha. Campinas: Autores Associados, 2006. (Coleção Educação Contemporânea)

VAN DIJCK, J. Imagenation: popular images of genetics. Basingstoke: MacMillan, 1998.

VAN DIJCK, J. The Transparent Body: a cultural analysis of medical imaging (in vitro: the cultural mediations of biomedical science). Washington: University of Washington Press, 2005.

VAN DIJCK, J. Picturizing science: the science documentary as multimedia spectacle. International Journal of Cultural Studies, 9(1): 5-24, 2006. Disponível em: < http://ics.sagepub.com/cgi/content/abstract/9/1/5>. Acesso em: 7 nov. 2008.

VAN DIJCK, J. Mediated Memories in the Digital Age. Stanford: Stanford University Press, 2007.

VAN DIJCK, J. Users like you? Theorizing agency in user-generated content. Media, Culture \& Society, 31(1): 41-58, 2009.

VEJA. DE MARI, J. Além dos limites. Veja. São Paulo, edição 1.642, seção Saúde, p. 172-174, 29 mar. 2000.

VEJA. O mapa do 21. Veja. São Paulo, edição 1.649, seção Genética, p. 86, 17 maio 2000.

VEJA. VARELLA, F. \& POLES, C. Check-up. Veja. São Paulo, edição 1.655, seção Especial, p. 118-125, 28 jun. 2000.

VEJA. Retratos do bebê antes do parto. Veja. São Paulo, edição 1.769, seção Guia Filho, p. 108, 18 set. 2002.

VEJA. WÜSTHOF, R. A terrível escolha. Veja. São Paulo, edição 1.896, seção Ética, p. 110-111, 16 mar. 2005.

VEJA. O relógio biológico deles. Veja. São Paulo, edição Especial 'A melhor idade', seção Família, 31 ago. 2005.

VEJA. BerGAMO, G. O doutor é animal. Veja. São Paulo, edição 1.933, 
seção Saúde, p. 66-68, 30 nov. 2005.

VEJA. A descoberta da molécula 'Down'. Veja. São Paulo, seção Ciência, 6 dez. 2005. Disponível em: <http://veja.abril.com.br/noticia/arquivo/descoberta-molecula-down>. Acesso em: 28 nov. 2006.

VEJA. Estudo indica gene causador de Down. Veja. São Paulo, seção Ciência, 6 jul. 2006. Disponível em: <http://veja.abril.com.br/noticia/arquivo/estudo-indica-gene-causador-down>. Acesso em: 28 nov. 2006.

VEJA. Síndrome de Down: origem em células-tronco. Veja. São Paulo, edição 2.076, Notícias on-line, seção Ciência e Saúde. (Resumo de pesquisa divulgada pela BBC Brasil, em 5 set. 2008) Disponível em: <http:// www.bbc.co.uk/portuguese/reporterbbc/story/2008/09/ 080905_sindromedowngene_np.shtml>Acesso em: 11 mar. 2009.

VEJA. BUCHALLA, A. P. Teste genético para 140 milhões. Veja. São Paulo, edição 2.090, seção Medicina, p. 144-145, 10 dez. 2008.

VEJA. Exame pré-natal poderá acusar autismo. Veja. São Paulo, edição 2.095, Notícias on-line, seção Ciência e Saúde, 12 jan. 2009. Disponível em: <www.abril.com.br/noticias/geral/exame-pre-natal-podera-acusarautismo-233132.shtml> Acesso em: 11 mar. 2009.

WATERS, M. Globalization. London: Routledge, 2001.

WATTS, G. (Ed.) Hype, Hope and Hybrids: science, policy and media perspectives of the Human Fertilisation and Embryology Bill. London: AMA, MRC, SMC, Wellcome Trust, 2009. Disponível em: <www.acmedsci.ac.uk/ p101puid151.html>. Acesso em: 12 dez. 2009.

WERNECK, C. Coleção Meu Amigo Down: na rua, na escola, em casa. Rio de Janeiro: WVA, 1994.

WERNECK, C. Um Amigo Diferente? Rio de Janeiro: WVA, 1996.

WILLIAMS, A. et al. UK national newspaper coverage of hybrid embryos: source strategies and struggles. Cardiff: Report Cardiff: the risk, science and the media research group/Cardiff University School of Journalism, Media and Cultural Studies/AMS, 2009. (Relatório Final de Pesquisa) 
<http://www.thet21travelingafghanproject.com>

$<$ http://teachwithmovies.org/guides/gattaca.html>

$<\mathrm{http}$ ://havefallendown.blogspot.com>

$<$ http://willswebplace.blogspot.com>

$<$ http://gotsnow.org >

$<$ http://hiddentreasuresthet21journey.blogspot.com>

$<$ http://megansgot47.blogspot.com>

$<\mathrm{http}$ ://churchillchronicle.blogspot.com>

$<$ http://hapagirlhapafamily.blogspot.com>

$<$ http://zoromski.blogspot.com>

$<$ http://mybluelobster.blogspot.com>

$<$ http://www.serdiferenteenormal.org.br $>$ 
Formato: $16 \times 23 \mathrm{~cm}$

Tipologia: Carleton e Carmina Lt Bt

Papel: Pólen Bold 70g/m2 (miolo)

Cartão Supremo $250 \mathrm{~g} / \mathrm{m} 2$ (capa)

Impressão e acabamento: Imos Gráfica e Editora Ltda.

Rio de Janeiro, julho de 2012

Não encontrando nossos títulos em livrarias, contactar:

EDITORA FIOCRUZ

Av. Brasil, 4036, $1^{\circ}$ andar, sala 112 - Manguinhos

21040-361 - Rio de Janeiro - RJ

Tel.: (21) 3882-9039 e 3882-9007

Telefax: (21) 3882-9006

editora@fiocruz.br

www.fiocruz.br/editora 